\title{
The Private Foundation's Topsy Turvy Road in the American Political Process
}

William H. Byrnes IV

Follow this and additional works at: https://scholarship.law.tamu.edu/facscholar

Part of the Law Commons

\section{Recommended Citation}

William H. Byrnes IV, The Private Foundation's Topsy Turvy Road in the American Political Process, 4 Hous. Bus. \& Tax L.J. 496 (2004).

Available at: https://scholarship.law.tamu.edu/facscholar/496

This Article is brought to you for free and open access by Texas A\&M Law Scholarship. It has been accepted for inclusion in Faculty Scholarship by an authorized administrator of Texas A\&M Law Scholarship. For more information, please contact aretteen@law.tamu.edu. 
COPYRIGHT @ 2004 HOUSTON BUSINESS AND TAX LAW JOURNAL. ALL RIGHTS RESERVED.

\title{
THE PRIVATE FOUNDATION'S TOPSY TURVY ROAD IN THE AMERICAN POLITICAL PROCESS
}

\author{
William H. Byrnes, IV" \\ TABLE OF CONTENTS
}

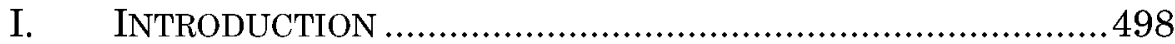

II. FRAMING THE STUDY: THE MODERN ECONOMIC

SIGNIFICANCE OF THE FOUNDATION SECTOR ......................500

III. 1536-1739: INHERITING ENGLAND'S SEE-SAW

LEGISLATIVE TREATMENT OF CHARITABLE

INSTITUTIONS

IV. 1776-1850: PERIOD OF POST-COLONIAL DISTRUST AND

GRADUAL ACCEPTANCE OF CHARITABLE INSTITUTIONS.....503

V. 1850-1860: UNIVERSAL PROPERTY TAXES CRYSTALLIZE

THE TAX EXEMPTION DEBATE ............................................505

VI. 1860-1870: TO EXEMPT OR NOT TO EXEMPT? THE

CONGRESSIONAL DEBATE..................................................507

A. 1870-1880: Parton, Eliot and the Massachusetts

Exemption Debate ..................................................510

B. Parton's Critique …………….................................510

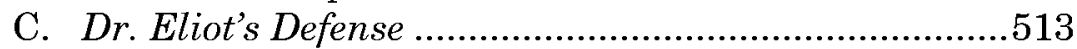

D. The Massachusetts' Decision .......................................521

E. The Massachusetts' Minority Report ..........................522

VII. 1890-1900: THE 1864 CONGRESS' FEAR PLAYS OUT ON

THE 1894S CONGRESS EXPANDING EXEMPTIONS AND

THE SCOPE OF EXEMPTION

VIII. 1900-1940: THE RISE OF THE INDUSTRIALIST PRIVATE

FoundATION, THE (IGNORED) POPULIST RESPONSE OF THE WALSH COMMITTEE

IX. 1913-1940: THE EXPANSION OF EXEMPTIONS,

\footnotetext{
"Associate Professor and Director, Walter H. \& Dorothy B. Diamond International Tax Program, St Thomas University School of Law, B.A. (Political Economics, Tulane), J.D. (Civil Law, Loyola), LL.M. (European Business \& Taxation, Amsterdam), Fellow (International Bureau of Fiscal Documentation \& Amsterdam). I express much appreciation to my wife, Christine, for her utmost patience; to my research assistant Devon A. Stoney and to the St. Thomas Law Library staff who assisted with long nights of microfilm and microfiche research, and to Kelly O'Connell for the constant brainstorming sessions.
} 
CONTRACTION OF EXEMPTION'S SCOPE, AND THE

INITIATION OF THE CHARITABLE DEDUCTION .538

A. 1940-1950: Congress Considers Eliminating the Charitable Exemption, Distinguishes the Private Foundation, Increases Yet Eliminates the Charitable Deduction

B. The Tempered 1950 Act Curbs Abuse

C. The 1952 Cox Committee. .553

D. The 1954 Reece Committee - If at First You Don't Succeed, Try, Try Again

E. Did the Reports Have Any Affect? Congress Increases the Deduction.

X. 1960-1970: Patman's Crusade Against the Private

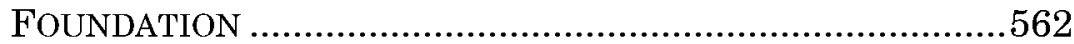

XI. THE TREASURY REPORTS................................................569

XII. PETERSEN COMMISSION ...............................................5575

XIII. THE 1969 ACT................................................................579

A. Codification of the Private Foundation Definition .....581

B. Codification of the Operating Foundation

Definition ...................................................................583

C. New and Amended Regulation ...................................584

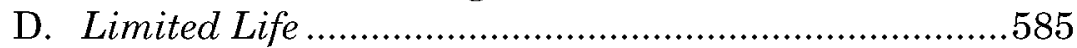

E. Private Foundation's Excise Tax................................586

F. Private Foundation's Self-Dealing .............................587

G. Private Foundation's Minimum Distribution .............588

H. Private Foundation's Prohibited Activities .................589

I. Universal Reporting Requirements ............................590

J. Universal Applicability of the Unrelated Business Income Tax .................................................................590

K. Charitable Deduction ................................................592

XIV. CONCLUSION ...........................................................593 
"When the Finance Committee began public hearings on the Tax Reform Act of 1969 I referred to the bill as ' 368 pages of bewildering complexity.' It is now 585 pages . . . Much of this complexity stems from the many sophisticated ways wealthy individuals - using the best advice that money can buy-have found ways to shift their income from high tax brackets to low ones, and in many instances to make themselves completely tax free. It takes complicated amendments to end complicated devices." Senator Russell Long, Chairman, Finance Committee ${ }^{1}$

\section{INTRODUCTION}

From the turn of the twentieth century, Congress and the states have uniformly granted tax exemption to charitable foundations, and shortly thereafter tax deductions for charitable donations. But an examination of state and federal debates and corresponding government reports, from the War of Independence to the 1969 private foundation reforms, clearly shows that politically, America has been a house divided on the issue of the charitable foundation tax exemption. By example, in 1863, the Treasury Department issued a ruling that exempted charitable institutions from the federal income tax but the following year, Congress rejected charitable tax exemption legislation. However thirty years later, precisely as feared by its 1864 critics, the 1894 charitable tax exemption's enactment carried on its coat tails a host of non-charitable associations, such as mutual savings banks, mutual insurance associations, and building and loan associations.

Yet, the political debate regarding exemption for the noncharitable associations did not nearly rise to the level expended upon that for philanthropic, private foundations established by industrialists for charitable purposes in the early part of the century. But the twentieth century debate upon the foundation's charitable exemption changed little from that posited between the 1850s and 1870s by Presidents James Madison and Ulysses Grant, political commentator James Parton, and Dr. Charles Eliot, President of Harvard. The private foundation tax exemption evoked a populist fury, leading to numerous, contentious, investigatory foundation reports from that of 1916

1. 115 Cong. Rec. S14, 944 (1969) (statement of The Hon. Russell B. Long), reprinted in 1969 U.S.C.C.A.N. 2391, 2490. 
Commission of Industrial Relations, 1954 Reece Committee, 1960 Patman reports, and eventually the testimony and committee reports for the 1969 tax reform. These reports uniformly alleged widespread abuse of, and by, private foundations, including tax avoidance, and economic and public policy control of the nation. The private foundation sector sought refuge in the 1952 Cox Committee, 1965 Treasury Report, and 1970 Petersen Commission, which uncovered insignificant abuse, concluded strong public benefit, though recommending modest regulation.

During the charitable exemption debates from 1915 to 1969 , Congress initiated and intermittently increased the charitable income tax deduction while scaling back the extent of exemption for both private and public foundations to the nineteenth century norms. At first, the private foundation's lack of differentiation from general public charities protected their insubstantially regulated exemption. But in 1943, contemplating eliminating the charitable exemption, Congress rather drove a wedge between private and public charities. This wedge allowed the private foundation's critics to enact a variety of discriminatory rules, such as limiting its charitable deduction from that of public charities, and eventually snowballed to become a significant portion of the 1969 tax reform's 585 pages.

This article studies this American political debate on the charitable tax exemption from 1864 to 1969, in particular, the debate regarding philanthropic, private foundations. The article's premise is that the debate's core has little evolved since that between the $1850 \mathrm{~s}$ and $1870 \mathrm{~s}$. To create perspective, a short brief of the modern economic significance of the foundation sector follows. Thereafter, the article begins with a review of the preand post-colonial attitudes toward charitable institutions leading up to the 1800 s debates, illustrating the incongruity of American policy regarding whether and to what extent to grant charities tax exemption. The 1800 s state debates are referenced and correlated to parts of the $1900 \mathrm{~s}$ federal debate to show the similarity if not sameness of the arguments against and justifications for exemption. The twentieth century legislative examination primarily focuses upon the regulatory evolution for foundations. Finally, the article concludes with a brief discussion of the 1969 tax reform's changes to the foundation rules and the significant twentieth century legislation regulating both public and private foundations. 


\section{Framing The Study: The Modern Economic Significance OF THE FOUNDATION SECTOR}

From 1995 to 2003 , section 501 tax exempt foundations increased from $1,065,378$ to $1,308,583$, with those filing form 990 rising from 347,525 to $457,329 .^{2}$ This tax exempt sector is composed primarily of "health service organizations $(53.9 \%)$, education and legal services (18.3\%), social and legal services $(12 \%)$, and religious organizations $(9.7 \%){ }^{{ }^{3}}$ During this period, gross receipts of these nonprofits grew from $\$ 1.12$ trillion to $\$ 1.87$ trillion, and assets nearly doubled from $\$ 1.49$ trillion to over $\$ 2.67$ trillion. In 1998 , nonprofits employed nearly eleven million full and part-time employees, accounting for $7.1 \%$ of the national labor force. ${ }^{4}$ As of 1995, non-religious nonprofits' operating expenditures represented nearly $7 \%$ of GDP at just over $\$ 500$ billion. ${ }^{5}$

From 1990 to 2002, contributions, gifts and grants increased from $\$ 70$ billion to $\$ 203$ billion at the average rate of $9 \%$ annually. ${ }^{6} \quad$ In 2002, individuals donated an estimated $\$ 183.7$ billion, representing $76.3 \%$ of donations, followed by foundations at $\$ 26.9$ billion (11.2\%) and corporations at $\$ 12.19$ billion $(5.1 \%)^{7}$ Of these donations, religious causes received $35 \%$ ( $\$ 84.28$ billion), education institutions $13.1 \% \quad(\$ 31.64$ billion $)$ health organizations $7.8 \%$ ( $\$ 18.87$ billion), human services $7.7 \%$ ( $\$ 18.65$ billion), arts related groups $5.1 \%$ ( $\$ 12.22$ billion), public policy groups $4.8 \%$ ( $\$ 11.6$ billion), and environmental and animal groups $2.7 \%$ ( $\$ 6.59$ billion $){ }^{8}$ Approximately $21 \%$ of the donations

2. National Center for Charitable Statistics ("NCCS"), available at http:// nccsdataweb.urban.org/tablewiz/tw_bmf.php (last visited Sep. 17, 2003). See also I.R.S. Data Book 2000, I.R.S. Pub. 55B, 24 (2001).

3. Nina J. Crimm, Shortcomings in U.S. Federal Tax Regulatory Regime of Private Foundations: Insights for Australia, 35 VAND. J. TRANSNAT'L L. 749, 779 (2002) (providing statistics as of 1997).

4. Crimm, supra note 3 , at 778-79 (noting that a further 5.7 million full-time volunteers represented an additional $3.7 \%$ of the labor force).

5. $\quad I d$. at 779

6. Figures and annual growth in average giving calculated according to Harvy Lipman, Giving in 2002 Didn't Outpace Inflation, Report Says, CHRON. PHILANTHROPY, June 2003, at 7 (calculated based on data from National Center for Charitable Statistics, supra note 2 (quoting data from American Association of Fund-Raising Counsel Trust for Philanthropy Fulfillment Department, Giving USA 2003, available at http:// www.givingusa.org.)) The total giving for individuals, corporations and foundation was significantly higher at $\$ 241$ billion. See Gerald Auten \& David Joulfaian, Charitable Contributions and Intergenerational Transfers, 59 J. PUB. ECON. 55 (1996) (stating that in 1992 , individuals with itemized deductions contributed $\$ 60$ billion to charity. Thus, the figures of NCCS may be understated.).

7. Calculated based on data from Lipman, supra note 6, at 7.

8. See American Association of Fund-Raising Counsel Trust for Philanthropy 
( $\$ 52.45$ billion) went to either private foundations or were not directed to a particular charity. ${ }^{9}$

\section{1536-1739: INHERITING ENGLAND'S SEE-SAW LEGISLATIVE TREATMENT OF CHARITABLE INSTITUTIONS}

The English 1601 Statute of Charitable Uses is credited as the historical origin of U.S. charity law. ${ }^{10}$ However, in English history leading up to the U.S. War of Independence, in particular as regards land transfers, charitable institutions did not generally enjoy the favor of government. ${ }^{11}$ Rather, the sovereign viewed charities as means to deprive the government of revenue through perpetually restricting land transfer. ${ }^{12}$ Two hundred years, from Henry VIII's voidance of charitable uses to obtain revenue, Elizabeth I's charitable exception to Henry's legislation, and Parliament's response to restrict application of Elizabeth's response, exemplifies the struggle of early charitable institutional policy inherited by the colonies.

In order to finance his reign, Henry VIII seized the Catholic Church's and universities' lands and with parliament enacted The Statute of Uses in 1536 and The Chantries Act in $1545 .^{13}$ The Statute of Uses, in enacting the rule against perpetuities, terminated the situation that most English land, in order to escape feudal dues, was held from family generation to

Fulfillment Dep't, Giving USA 2003, available at http://www.gvingusa.org (stating in 1998 Americans donated more like $45 \% \$ 76.06$ billion of $\$ 172.52$ billion, to religious causes).

9. Calculated based on data from Lipman, supra note 6, at 3 .

10. Tanya D. Marsh, A Dubious Distinction: Rethinking Tax Treatment of Private Foundations and Public Charities, 22 VA. TAX REV. 137, 138 (2002); Lars G. Gustafsson, The Definition of "Charitable" for Federal Income Tax Purposes: Defrocking the Old and Suggesting Some New Fundamental Assumptions, 33 Hous. L. REv. 587, 609 (1996).

11. See Evelyn Brody, Charitable Endowments and the Democratization of Dynasty, 39 ARIZ. L. REV. 873, 899-906 (1997) (explaining that English law historically barred devises for any charitable purpose). The earliest charitable institutions, circa 1200 s$1400 \mathrm{~s}$, primarily encompassed Catholic orders. Id. Charitable institutions, such as schools, hospitals, and churches were sometimes favored and funded by the Crown, but also periodically fell out of favor, leading to escheat or redeployment of assets. See Norman Alvey, From ChaRITy to OXFAM: A SHORT History OF CHARITY LEGISLATION 21-22 (1995).

12. See Brody, supra note 11, at 900-01. Uses, the precursor of trusts, were employed by the property owning servants of the King, such as Knights and Lords, to avoid feudal dues. Id. The Chancery recognized the use whereby a Knight could grant the perpetual legal ownership of his land to a party (i.e., the church represented by the bishop) but maintain the beneficial use for himself and future heirs. Id. Through the use, legal title did not pass, avoiding attracting feudal transfer duties of the King and his hierarchy. Id.

13. Id. at $901,909-10,2911-13$. Henry VIII was by no means the first king to dissolve monasteries. Id. at 909. 
generation in dynastical, perpetual trusts owned by the Church. ${ }^{14}$ The Chantries Act provided for escheat of colleges' possessions. ${ }^{15}$ The government established as an organ of itself with tax-exempt status by its sovereign nature the Church of England, replacing the Catholic Church. ${ }^{16}$

See-sawing in favor of charitable institutions, under Elizabeth I in 1597, parliament enacted a charitable corporation act that exempted specified institutions from government charges and the requirement of government consent when formed for the following purposes:

to erect, found, and establish, one or more hospitals, maison de Dieu, abiding places, or houses of correction, ... as well as for the finding, sustentation, and relief of the maimed, poor, needy or impotent people, as to set the poor to work, to have continuance forever, and from time to time place therein such head and members, and such number of poor as to him, his heirs and assigns should seem convenient. ${ }^{17}$

Furthering Elizabeth I's charitable incorporation statute by suppressing the application of Henry's Statute of Uses and its rule against perpetuities, four years later Parliament enacted the Statute of Charitable Uses, 1601, allowing real property transfers to perpetual charitable trusts. ${ }^{18}$ The Statute provided for exemption from the Statute of Uses for a transfer to a charity that provided:

relief of aged, impotent and poor people,... maintenance of sick and maimed soldiers, schools of learning, free schools, and scholars in universities, ... repair of bridges, ports, havens, causeways, churches, sea-banks and highways, ... education and preferment of orphans,... relief, stock or maintenance of houses of correction, ...

14. Brody, supra note 11 , at 901 .

15. Id. at $912-13$.

16. See Christine Roemhildt Moore, Comment, Religious Tax Exemption and The “Charitable Scrutiny" Test, 15 REG. U. L. REV. 295, 298-99 (2002-2003).

17. See James J. Fishman, The Development of Nonprofit Corporation Law and an Agenda for Reform, 34 EMORY L.J. 617, n.65 (1985).

18. Gustafsson, supra note 10, at 605 (citing An Act to redress the Mis-employment of Lands, Goods, and Stocks of Money heretofore given to Charitable Uses, 1601, 43 Eliz., ch. 4 (Eng.)); Brody, supra note 11, at 901. 
marriages of poor maids, . . . aid and help of young tradesman, handicraftsman and persons decayed, relief of prisoners, . . aid of any poor inhabitants. ${ }^{19}$

However, during the late sixteenth century and seventeenth century, the Crown often piecemeal interfered with religious charitable trusts, either voiding the trust or employing cy pres to divert the trust assets to the Crown's favored religion. ${ }^{20}$ Charitable institutions once again falling out of the Crown's blanket favor, two hundred years after and in the same vein as the Statute of Uses, Parliament revived a specific anti-charity statute, The Mortmain Act, in 1736. ${ }^{21}$ The Mortmain Act of 1736 invalidated real property transfers to any charity mortis causa as well as inter vivos transfers made one year or less before death. ${ }^{22}$ Though this statute limiting the funding of charities remained English law until The Charities Act, 1960, Parliament modified it in 1891 to allow for exceptions for devised property not to be used for investment, thus endowment, purposes. ${ }^{23}$

\section{1776-1850: PERIOD OF POST-COLONIAL DisTRUST AND GRADUAL ACCEPTANCE OF CHARITABLE INSTITUTIONS}

The Colonies inherited the English common law and its history, but without the 1736 Mortmain Act. ${ }^{24}$ In addition to the common law, the colonialists also inherited the English distrust of perpetual land restriction, the power exercised by the Catholic Church because of its substantial land holdings, and the distrust of the Anglican Church because it was an organ of the English government. $^{25}$ During the early period after the War of

19. Oliver A. Houck, With Charity For All, 93 YALE L.J. 1415, 1422 (1984) (quoting Charitable Uses Act, 1601, 43 Eliz., ch. 4).

20. AlveY, supra note 11, at 10-11.

21. See Gustafsson, supra note 10, at 606, 649 n.62 (noting that Mortmain statutes had previously been enacted in England but the Statute of Charitable Uses substantively repealed them); see also Brody, supra note 11, at 903 (noting that Parliament's sentiments for legislating the statute are uncertain, but may have been due to anticlerical feelings).

22. ALVEY, supra note 11, at 11 .

23. Brody, supra note 11, at $905 \mathrm{n} .147$ (noting that the statute was modified in 1891 to allow either the court or the Charity Commissioners to grant exception for a mortis causa real property transfer to charity as long as the property was to be used for charitable activity rather than for investment purposes).

24. Id. at 906 .

25. Id. After the revolution, the colonialists felt the same distrust for the Church of England as that for Rome. See Fishman, supra note 17, at 624 (commenting on the ongoing anti-charity-anti-clerical atmosphere of the post-colonial period); Note, The Enforcement of Charitable Trusts in America: A History of Evolving Social Attitudes, 54 VA. L. REv. 436, 443-44 (1968) (same). This distrust of the Catholic Church reached into the late nineteenth century, creating opponents of tax exemption for religious institutions. 
Independence, some states legislatures and courts exercised this inherited distrust by voiding the establishment of charitable trusts, denying the grant of charters for charitable corporations, and constricting transfers to both. ${ }^{26}$ Seven states, being Maryland, Michigan, Minnesota, New York, Virginia, West Virginia, and Wisconsin, voided charitable trusts. ${ }^{27}$ In 1829, the New York legislature enacted a form of the English Mortmain law severely restricting devises to charity and codified a trust law regime without the inclusion of the charitable trust, thus severely restricting the likelihood a charitable gift would be upheld. ${ }^{28}$

By contrast, many states, in their constitutions and well as by statute, borrowed from Elizabeth I's 1597 statute to protect incorporation for charitable purposes. ${ }^{29}$ Charitable incorporations included churches, charities, educational institutions, library companies, and fire companies. ${ }^{30}$ The policy behind the charitable statutes included promotion of freedom of religion, easing legislative workloads, and easing of incorporation

See Stephen Diamond, "Of Budgets and Benevolence: Philanthropic Tax Exemptions in Nineteenth Century America", 17 (Oct., 1991) (Address at the N.Y.U. School of Law, Program on Philanthropy, Conference on Rationales for Federal Income Tax Exemption, Oct. 1991), http://www.law.nyu.edu/ncpl/abtframe.html (last visited Jul. 9, 2003); see also Erika King, Tax Exemptions and the Establishment Clause, 49 SYRACUSE. L. REV. 971, $1037 \mathrm{n} .8$ (1999) (quoting James Madison's statement that "[t]here is an evil which ought to be guarded [against] in the indefinite accumulation of property from the capacity of holding it in perpetuity by ecclesiastical corporations.").

26. See Brody, supra note 11, at 906-10; Fishman, supra note 17, at 623-25; John Witte, Jr., Tax Exemption of Church Property: Historical Anomaly or Valid Constitutional Practice?, 64 S. CAL. L. REV. 363, 384-85 (1991).

27. 4 AUSTIN WAKEMAN SCOTT, The LAW OF TRUSTS $\S 348.3$ (3d ed. 1967). Some states, such as Virginia in 1792, repealed the pre-independence English statutes, including the Statute of Charitable Uses. The lack of the Statute of Charitable Uses consequence, as argued by the States and agreed by the Supreme Court in Trustees of Philadelphia Baptist Ass'n v. Hart's Executors, 17 U.S. 1, 30-31 (1819), was that charitable trusts without stated beneficiaries were void because of the lack of common law precedent for establishing a trust without a beneficiary. Nina J. Crimm, An Explanation of the Federal Income Tax Exemption for Charitable Organizations: A Theory of Risk Compensation, 50 FLA. L. REV. 419, 427 (1998) (noting that this decision and ones following it led to the establishment of charitable corporations instead of trusts to receive donations).

28. Brody, supra note 11, at 908; Fishman, supra note 17, at 627, 634. On page 634, Professor Fishman notes that in 1840 , New York enacted legislation allowing property donations to incorporated colleges and other charitable institutions.

29. Fishman, supra note 17, at 623 (noting that Massachusetts, Pennsylvania, Vermont, and New Hampshire constitutionally protected charities).

30. Fishman, supra note 17, at 631-32; see also Moore, supra note 16, at 299 (noting that most new states had an established state church, which took over the former role of the Church of England as an organ of the state, and that, after disestablishment from the state, tax exemption continued as a matter of course). 
procedures. ${ }^{31} \quad$ But not all states had charitable incorporation statutes. Some states, such as Virginia, denied granting charters to charitable corporations for several years. ${ }^{32}$ Of the states with charitable incorporation statutes, all contained restrictions regarding maximum income, expenditure for charitable purpose, as well as reporting rules to guard against the accumulation of property. ${ }^{33}$

\section{1850-1860: UNIVERSAL PROPERTY TAXES CRYSTALLIZE THE TAX EXEMPTION DEBATE}

By the middle of the century, the Supreme Court of the United States, by examination of the Statute of Charitable Uses and common law applicable in the U.S., derived a broad definition for charity. ${ }^{34}$ The Court upheld contributions to "charitable" institutions based upon the factors of the institutions' public purpose and freedom from private gain. In 1860, upholding a devise and bequest for establishing two education institutions, the Court stated "a charity is a gift to a general public use, which extends to the rich, as well as to the poor" and that "[a]ll property held for public purposes is held as a charitable use, in the legal sense of the term charity." ${ }^{35}$ In 1877, upholding a devise to an orphan's hospital, the Court presented that:

A charitable use, where neither law nor public policy forbids, may be applied to almost any thing that tends to promote the well-doing and wellbeing of social man .... 'Whatever is given for the love of God, or the love of your neighbor, in the catholic and universal sense,- - given from these motives and to these ends, free from the stain or taint of every consideration that is personal, private, or selfish.' ${ }^{36}$

31. See Fishman, supra note 17, at 632-33.

32. See Witte, supra note 26, at 385; Brody, supra note 11, at 906-07; Nina J. Crimm, A Case Study of a Private Foundation's Governance and Self-Interested Fiduciaries Calls for Further Regulation, 50 EMORY L.J. 1093, 1099 (2001); Fishman, supra note 17 , at $631 \mathrm{n} .70$ (noting that corporate charters were granted to only 355 businesses during the eighteenth century).

33. See Fishman, supra note 17, at 634; see also Brody, supra note 11, at 909 (noting that a few state statutes still constrict the ability to devise to, or the holdings of, charitable corporations).

34. See Gustafsson, supra note 10, at 609-10.

35. Perin v. Carey, 65 U.S. $465,494,506$ (1860).

36. See Gustaffson, supra note 10 , at 610 . 
Until the mid 1850s, many state statutes allowed incorporation for charitable purposes but did not necessarily exempt these corporations from state tax. ${ }^{37}$ Before the 1830s, the states did not have a universal tax system and thus, while tax exemption expressed government favoritism, it was not practically significant. ${ }^{38}$ However, the 1830 s enactment of universal property tax regimes brought the issue of exemption to the fore. ${ }^{39}$ During the remainder of the century, several states enacted limited tax exemption for churches and educational institutions. ${ }^{40}$ By example, many states exempted from property tax the land upon which a church stood, but taxed the church's income, including ministerial, rental, and endowment. ${ }^{41}$ The Massachusetts statutory tax exemption for religious, educational, and charitable organizations, applying to Harvard University, did not include an exemption for real estate or businesses held for purposes of revenue. ${ }^{42}$

Supporters and critics of exemption debated three primary policies concerning the granting of limited tax exemption for churches. From a public policy perspective, the general community felt that the church served as the communal epicenter. ${ }^{43}$ Church supporters also put forward that churches provide the benefits of encouragement of personal morality, public spiritedness, and democratic values. ${ }^{44}$ Critics countered that from an equity standpoint, exemption inequitably expressed state favoritism for religious groups over non-religious property

37. For a historical summary of nineteenth century American policy regarding the ad hoc to infrequent granting of tax exemption for charitable institutions, see Diamond, supra note 25 , at 12 . For a description of colonial church exemptions and taxation of certain income producing properties, see Witte, supra note 26 , at 372-74.

38. See Diamond, supra note 25, at 8-9.

39. See id. at page 10; Witte., supra note 26 , at $385-86$.

40. See Diamond, supra note 25 , at 12.

41. Id.

42. Chas. W. Eliot, The Exemption from Taxation of Church Property, and THE Property of EDUCATIONAL, Literary AND CHARITABle Institutions, APPENDix to THE REPORT OF THE COMMISSIONERS APPOINTED TO INQUIRE INTO THE EXPEDIENCY OF REvising or Amending the Laws ReLATED to TAXation and ExEmPtion Therefrom 367,386 (1875) (stating that Harvard paid tax on its various business holdings in Boston, save one specifically exempted from tax in its Charter).

43. See Witte, supra note 26 , at $374-75$. The underpinnings of this public policy to exempt the church drew from the historical exemption justified by two causes. Most states had an official church established by government as an organ of the state government, continuing the English tradition. Id. Second, the Churches acted as the community services center of most townships, thus providing the local government services that otherwise it should undertake. See id. at 375 . This second justification foreshadowed the government benefit analysis employed by Dr. Eliot. See infra Part $\mathrm{VI}(\mathrm{C})$.

44. John W. Whitehead, Church / State Symposium Tax Exemption and Churches: $A$ Historical And Constitutional Analysis, 22 CumB. L. REv. 521, 539-40 (1991-1992). 
owners. ${ }^{45}$ Also, exemption critic James Madison warned that the accumulation of exempt Church property would eventually result in religion influencing the political process. ${ }^{46}$

Supporters provided a tax policy justification that the limited exemptions applied only to the charitable institution's property that produced insignificant income, such as cemeteries, the church, the school, thus the exemption's revenue effect would be slight. ${ }^{47}$ Critics responded that whereas both exempt and nonexempt persons used the state's services, only non-exempt persons paid for them with resultant increased burdens upon them. ${ }^{48}$ Supporters retorted to this argument of an inequitable burden with a government benefit argument that the churches provided public services, such as orphanages and soup kitchens, not performed by non-exempt payers. ${ }^{49}$

From an economic policy justification, supporters forwarded that because many of these exempt institutions did not produce much revenue, the tax could not be collected, leading to unpopular land seizure. ${ }^{50}$ Critics responded that the exemption primarily benefited wealthy churches with valuable property and significant income rather than the humble ones with low land value and de minimis income. ${ }^{51}$ Again employing the subsidy argument, supporters argued that all church income, regardless of church size, went to provide charitable services, such as religious activity and caring for the poor. ${ }^{52}$

\section{1860-1870: TO EXEMPT OR NOT TO EXEMPT? THE CONGRESSIONAL DEBATE}

Before the Civil War, federal revenues were generated through customs and excise taxes on specific commodities. ${ }^{53}$ In

45. Witte, supra note 26 , at 381 .

46. Id. at 382. This criticism of exemption, reiterated by President Ulysses Grant, most influenced the Walsh Commission's perspective on industrialists' foundations as well as that of the Reece Commission. See infra Parts VIII, IX(D).

47. See Diamond, supra note 25, at 14. In 1873, James Parton countered this justification, alleging examples of such charitable institutions producing extraordinary income. See infra Part VI.

48. See Witte, supra note 26 , at 381 .

49. Whitehead, supra note 44, at 540. Dr. Eliot further enunciated the government benefit, also known as the tax subsidy, argument that the state ought to grant exemption for the charitable provision of public service. See infra Part VI(C).

50. See Diamond, supra note 25 , at 14 . In 1873 , James Parton proffered a liberal argument of land distribution efficiency that could only be achieved through such unproductive property being seized and auctioned back into commerce. See infra Part VI.

51. See Witte, supra note 26 , at 382 .

52. See Whitehead, supra note 44 , at 539-40.

53. Id. at 541 . 
many cases, Congress exempted churches and other charitable institutions from the application of the tax. ${ }^{54}$ For example, in 1815 Congress exempted any "charitable, religious, or literary institution" from the household furniture tax. ${ }^{55}$ In 1863, the Treasury Department issued an administrative ruling that " $[t]$ he income of literary, scientific, or other charitable institutions, in the hands of trustees or others, is not subject to income tax," thus exempting them from the income tax imposed during the Civil War. ${ }^{56}$

In 1864 , over the issue of extending tax exemption to hospitals, the Senate debated whether to grant tax exemptions to charitable institutions. ${ }^{57}$ A New York merchant, James Roosevelt, bequeathed approximately one million dollars for the establishment and endowment of a New York hospital. ${ }^{58}$ This endowment led New York Senator Edwin Morgan, Sr. to introduce an amendment to exempt from tax all hospitals that offered free medical care to sick or disabled U.S. war veterans in order to encourage more such hospitals to be established by other grants. $^{59}$

Maine Senator William Fessenden responded with the policy decision of the Finance Committee: the granting of an exemption for one type of socially beneficial institution would inevitably burst the dam as every type of institution tried to squeeze through the exemption crack. ${ }^{60}$ In this regard, he stated:

There are many cases in which it seems to be a little hard to use the expression, to exact revenue; but the same reasoning that applies to this institution would apply to all eleemosynary institutions which have capital invested, and yet, if we undertake to make distinctions in connection

54. See id. (noting early tax legislation exempting churches from excise taxes and import duties).

55. $I d$.

56. Evelyn Brody, Of Sovereignty and Subsidy: Conceptualizing the Charity Tax Exemption, 23 J. CORP. L 585, 605 n.95 (1998); see also Diamond, supra note 25, at 15 (noting that the income tax was really an excise tax for the right to do business and thus was not likely meant to apply to Churches and philanthropies).

57. See Diamond, supra note 25 , at $15-16$.

58. See CONG. Globe, $38^{\text {th }}$ Cong., 1st Sess. 2755 (1864); Diamond, supra note 25, at 15.

59. See CONG. GLOBE 2755 (quoting Senator Morgan's statement that "[i]t would be a little severe... to have a tax imposed; and it has seemed to me to be very proper to encourage others to found similar institutions by exempting them from taxation."). Senator Morgan proposed the amendment to the Internal Revenue bill.

60. See Diamond, supra note 25 , at $15-16$. 
with revenue, there is no knowing where we shall stop....

... to begin to make exceptions would lead to infinite confusion; the amount would be very large in the end; every effort would be made to bring cases within the principle, if [sic] we tried to adopt a principle in reference to it, and we thought it entirely unsafe.

... that it would be entirely unsafe to begin a system of exemptions anywhere, and that it is best to leave all the property of the country to the operation of the general law. ${ }^{61}$

Second, the Finance Committee addressed the critique that an exemption is necessary to encourage charitable acts. It concluded that the charitable citizen benefited from his own acts because all charitable acts supported good government for the benefit of all citizens, stating:

There is no danger that the tax imposed would prevent any man from carrying out any good will that he might have toward founding an institution or aiding in support of an institution already founded. The considerations that induce him to do it are such that would not in any sense be affected by the fact that his money thus invested did, like all other money vested in the same way, aid in supporting the government;.... It is all for the benefit of the people, and the personal benefit to be attained to the people is to provide them with good Government and to support that Government. ${ }^{62}$

Siding with the Finance Committee's reasoning, the Senate rejected the amendment. ${ }^{63}$

61. Id. at 2755-56. The 1894 income tax and corresponding debates produced the exact result that the 1864 Congress sought to avoid, with different lobbies plying for exemption for a variety of non-charitable associations, such as life insurance companies. See infra Part VII.

62. CONG. GLOBE 2755-56.

63. Id. at 2756 . 


\section{A. 1870-1880: Parton, Eliot and the Massachusetts Exemption Debate}

Continued from the 1850 s, in the 1870 s the debate over property tax exemption for charitable institutions, primarily focusing on religious institutions, intensified. ${ }^{64}$ While most states only exempted from tax land upon which the church actually sat, several states considered, but did not pass, legislation to eliminate all exemptions. ${ }^{65}$ In 1874, Congress empowered the District of Columbia to enact a property tax which the District imposed on churches, but Congress repealed the tax five years later. ${ }^{66}$

During this period, church tax exemption critics noted that some churches were extraordinarily profitable thus well able to afford a tax burden, by example, selling their urban land profitably and relocating elsewhere, while other churches produced significant income through pew renting. ${ }^{67}$ Exemption supporters retorted that churches relocating from more valuable property to less valuable outside of the town center should not give rise to criticism. ${ }^{68}$ Also in justifying the income's exemption, they argued that the profits were not of a commercial nature but rather an ancillary one for supporting the churches' activities, in some cases accounting for a substantial portion of a church's income. ${ }^{69}$

\section{B. Parton's Critique}

In 1873, James Parton emerged as a chief critic of charitable institutions, in particular the Catholic Church. ${ }^{70}$ Parton forwarded both the populist and liberal arguments against granting tax exemptions, establishing the basis of most twentieth century arguments against the charitable exemption. ${ }^{71}$ President

64. See Diamond, supra note 25, at 17.

65. See id. at 18 .

66. Id. Churches applied for, and were granted, exemption on a case-by-case basis. Id. However, the tax led to some churches defaulting, with consequent property seizures. Id.

67. See id. at 20,31 (noting that Brooklyn's Plymouth Church rented its pews for fifty thousand dollars annually).

68. See ELIOT, supra note 42 , at 387

69. See Diamond, supra note 25, at 20; see also ELIOT, supra note 42, at 386-87; see infra Part VII(C).

70. See Diamond, supra note 25, at 18-19. James Parton, 1822-1891, was a prolific American nineteenth century biographer and political commentary writer. Id.

71. See Diamond, supra note 25, at 28. The criticisms articulated by Parton, as well as the responsive justifications by Dr. Eliot, replayed themselves in the 1916 Walsh Committee (see infra Part IX), 1953 Cox Committee (see infra Part IX(C)), 1954 Reece 
Ulysses Grant and Parton, drawing from James Madison concerns, warned that the inequitable concentration of untaxed institutional, primarily church, wealth would threaten democratic institutions, leading to political instability and bloodshed. $^{72}$ In 1875, President Grant, criticizing the vast concentration of untaxed church wealth, stated:

So vast a sum, receiving all the protection and benefits of government without bearing its portion of the burdens and expenses of the same, will not be looked upon acquiescently by those who have to pay the taxes. In a growing country, where real estate enhances so rapidly with time, as in the United States, there is scarcely a limit to the wealth that may be acquired by corporations, religious or otherwise, if allowed to retain real estate without taxation.... I would suggest the taxation of all property equally, whether church or corporation, exempting only the last resting place of the dead and possibly, with proper restrictions, church edifices. ${ }^{73}$

In the populist vein, Parton alleged that the wealthy churches abused their exemptions through building extraordinarily luxurious club houses for their rich congregations to socialize rather than employing their wealth for charitable purposes. $^{74}$ Finally, Parton argued that wealthy financiers established charitable institutions only to morally legitimize their "ill-gotten property." ${ }^{75}$ He condemned these institutions as

Committee (see infra Part IX(D)), 1960's Patman's Reports (see infra Part XI), 1965 Treasury Report (see infra Part XIII), Petersen Commission (see infra Part XIV), as well as in the various legislative policy debates regarding either the charitable deduction and its expansion or the regulation of private foundations.

72. See Diamond, supra note 25 , at 19 ; Witte, supra note 26 , at 382 . The argument that the concentration of wealth in exempt perpetual institutions damaged democracy became the primary justification for the 1916 Walsh Commission's call that industrialists' foundations be limited to a 25-year life span. See infra Part IX. This argument and recommendation of limited life continued through the 1954 Reece Committee (see infra Part IX(D)), Patman Reports (see infra Part XI), 1965 Treasury Report (see infra Part XIII), eventually being codified in 1969 , not as a limited life regulation, but rather as an allowable maximum shareholding in any given business (see infra Part XV).

73. Brody, supra note 56 , at 600.

74. See JAMEs PARTON, TAXATION OF ChURCh Property, at 11 (1873).

75. Id. at 12. Senator Peffer, Kansas, reiterated this view in the debate on the 1894 Tariff Act: “. . no man ever earned a million dollars in a year. .. Take the most prosperous merchant in the country. . . .He earns $\$ 10,000$ every year. No, he does not; he makes that much ... but he gains it off of the profits over and above those that were fair 
not established to undertake charitable purposes but rather to conjure adulation and fill the void during the founders' retirement. $^{76}$

Positing the liberal arguments against exemptions, Parton combined the moral Jacksonian liberals with the economic liberals. $^{77}$ He submitted the Jacksonian belief that charity stripped men of their spirit of self reliance, thus charity morally degraded men. ${ }^{78}$ He forwarded the liberals' economic contractual argument ${ }^{79}$ for tax equity: "Whatever property the state protects ought, I think, to contribute its proportion to the State's support." ${ }^{80}$ These two liberal positions combined led him to the conclusion that special exemptions stripped the favored charitable class and its recipients of the morality of self-reliance, while in the same breath creating the injustice of inequitable burden against the non-favored class. ${ }^{81}$

Fourth, positing another economic liberal criticism of exemption, taxation facilitated the competitive process of the elimination of inefficient use of property. ${ }^{82}$ This liberal theory of competition addressed the earlier economic justification that charitably employed land should not be taxed due to the lack of income to pay the tax. These Darwinian liberals argued that the non-income producing property unable to meet the property tax obligation should be confiscated and sold back into the system of commerce, allowing efficient uses for it to be found. ${ }^{83}$ Parton presented the example of a town with seventeen Protestant churches, stating that half were superfluous, acting on a drain of the available resources for all of them. ${ }^{84}$ The 1874 District of

and just between man and man ... Now I say that no man can honestly claim that which he has not earned. . ." CoNG. REc., 53rd Cong., 2d Sess. 6635 (1894) (statement of Sen. Peffer). This view continued to be expressed by all the 1912 presidential candidates and in the 1916 Commission on Industrial Relations. See infra Part IX.

76. PARTON, supra note 74 , at 12.

77. Diamond, supra note 25 , at 21 .

78. Id. at 22 .

79. Id. at 19 .

80. PARTON, supra note 74 , at 3 .

81. See Diamond, supra note 25, at 22.

82. See Diamond, supra note 25, at 19. According to Parton:

An institution exempt from taxation may be a very good fungus, but it comes short from being a living branch. Taxing ecclesiastical property, so far from being an injury to the church, would be one of those just, wise, and timely measures which benefit everybody and hurt nobody.... It would extinguish some feeble life; but it would strengthen and vivify the fittest, which would survive.

PARTON, supra note 74, at 4:

83. PARTON, supra note 74, at 4-5.

84. Id. According to Parton: 
Columbia property tax led to Church seizures; however, the resulting political backlash must have been the cause of the tax's repeal five years later because Congress returned all monies collected. ${ }^{85}$

\section{Dr. Eliot's Defense}

During 1875, Massachusetts considered eliminating charitable exemptions. ${ }^{86}$ Appearing before the Commission in order to protect his institution's exemption, the President of Harvard College, Dr. Charles Eliot, employed economic and public policy justifications to counter the liberal and populist critiques summarized by Parton. ${ }^{87}$ He drew first from the historical economic policy justification that charitable institutions provide beneficial public service, stating: "There is a return, both from a church and a college, and from a sewer and a highway, in the benefits secured to the community." $88 \mathrm{He}$ differentiated the State's return from the public service provided by churches, colleges and hospitals from that obtained from railroads, factories and steamships based on the altruism of the former versus the profit motive of the latter, concluding that "[t]he self-interest of no man, and of no association of men, would lead to the establishment of a university." ${ }^{\$ 9}$

\footnotetext{
Why, then, do they not unite? It is because none of them can quite succeed in dying. While there is life there is hope. They hold on, and will hold on, as long as it is possible for the annual expenses to be met. The law of survival of the fittest hungers for the extinction of half of them; but that beneficent law is balked and frustrated by the exemption from taxation. That blessed Bankruptcy, which Mr. Carlyle so justly extols as nature's remedy for superfluous and mismanaged activities, hangs over them threatening, but powerless, because they do not have to bear their just share of the public burdens.
}

Id. at 5. But see infra Part XI (noting that the 1965 Treasury Report eventually rejected this argument in that it concluded that the many small foundations established by groups enriched the pluralism of the U.S. social order).

85. See Diamond, supra note 25 , at 18.

86. Id. Regarding charitable institutions, Massachusetts provided exemption from tax for the personal property and real estate of literary, benevolent, charitable and scientific institutions. See REPORT OF THE COMMISSIONERS APPOINTED TO INQUIRE INTO THE ExPEDiency of Revising of Amending the LaWs ReLated to TaXation and EXEMPTION THEREFROM 152 (1875) [hereinafter 1874 MASS. REPORT].

87. See Diamond, supra note 25 , at $22-23$.

88. ELTOT, supra note 42 , at 369 .

89. Id. at 374-75. Dr. Eliot's exemption justification based on profit without private gain, derived from the earlier 1850 debates on church exemption, became the employed argument to bring mutuals and fraternal associations under the exemption provision of the 1894 Tariff Act. See remarks of Senator Hill infra Part VII. Further, Congress adopted this justification in the 1909 Payne Aldrich Tariff Act's exempt provision, specifying that the exempt association's net income may not be used for private gain. See 
He added a tax subsidy component to this justification, arguing a government-benefit analysis: "... the State believes, or at least believed when the exemption statute was adopted, that the indirect gain to its treasury which results from the establishment of the exempted institutions is greater than the loss which the exemption involves." ${ }^{90}$ He posited that "[s]uch is the absolute necessity of the public work which the institutions of religion, education and charity do, that if the work was not done by these private societies, the State would be compelled to carry it on through its own agents or through its own charge" ${ }^{" 91}$ and that "The State believes that the new road will be such a convenience to the community, that the indirect gain for making it will be greater than the direct and indirect loss." ${ }^{.92}$ Expanding on the tax subsidy justification, he furthered that all income producing property of the charitable institution should be tax exempt in that the income expands the institution's capacity to undertake the public work, such as education for the poor, to the relief of government. ${ }^{93}$

In support of the government benefit analysis argument, Dr. Eliot proffered that if Harvard was made liable for the fifty to sixty thousand dollars of tax that the city would impose in absence of the exemption, it may eliminate twelve to fifteen professor positions to produce the difference, and that as the land value, thus taxes, increased, more positions could be eliminated. ${ }^{94}$ The loss of these jobs would harm the institution's ability to provide quality education while reducing the local community's economic wage earners. ${ }^{95}$ Further, as the University library added books for use by all, the library also would be required to produce the annual income to pay the additional tax incurred based upon the additional value of the books. ${ }^{96}$ The Observatory would be closed because its total endowment income would be used to pay the tax burden. Finally, as the surrounding city increased in value, the tax burden would correspondingly

infra Part VII.

90. ELIOT, supra note 42 , at 370 .

91. Id. at 372 (discussing the tax subsidy argument).

92. Id. at 370 .

93. Id. at 375. According to Eliot: "Institutions of high education have never been self-supporting in any country; and there is no reason whatever to suppose that they can be. If they were made self-supporting, they would be inaccessible to the poor, and be maintained exclusively for the benefit of the rich." Id.

94. Id. at 390 . He further presented that the state would lose upwards of $25 \%$ of its education services through a repeal of the tax exemption. Id. at 391.

95. See id. at 391

96. Id. at 390 . 
increase upon the University. ${ }^{97}$

Critics retorted that the local citizens, while acknowledging the accrued benefits of charitable institutions, inequitably bore the tax exemption subsidy for the enjoyment of the entire country: ${ }^{98}$

Those who urge this objection admit that the public receives great benefit from churches, colleges and hospitals; but, as these institutions necessarily have local habitations, and taxes under our laws are locally levied, they allege that the particular cities or towns in which the institutions happen to be situated bear, in loss of taxable property, the so-called burden of their exemption, while the whole State, or perhaps the whole country, shares the public benefits which accrue from them. The public burdened, it is alleged, it not the same public as the public benefited. ${ }^{99}$

First, Dr. Eliot posited that charitable institutions did not produce significant benefit beyond locality. ${ }^{100}$ Next, Dr. Eliot argued that regardless of benefit beyond the locality bearing the burden, not granting a tax exemption did not necessarily lead to taxable property filling the vacant space. ${ }^{101}$

Following, he proffered that even if such revenue producing property did fill the void, then that taxable property immigrated from another locality, reducing the latter locality's tax base. ${ }^{102}$ Finally, he countered that exempt property is not a zero sum game locally between exemption and revenue but rather that the charitable institutions actually increased tax revenues by raising the value of the property in the community surrounding them, drawing new residents and consumers to the locality. ${ }^{103}$

Critics presented a further revenue loss argument regarding the migration of personal property, such as cash, through

97. See id. at 391.

98. In the 1894 Tariff Act debates, Senator Peffer posited this argument against Senator Hill's proposal for exemption of mutual saving banks, stating that the agricultural states would bear the burden of the Northern based association's exemption. See infra Part VII.

99. ELIOT, supra note 42 , at 376 .

100. Id. at 381 .

101. Id. at 376 .

102. Id. at 376,378 .

103. See id. at 377, 379-80. Dr. Eliot gave examples of colleges and churches increasing the land value of the community around them. Id. at 379-80. 
donations being sent from one locality to another. Dr. Eliot countered that each locality with exempt institutions equally obtained the possibility of receiving such gifted money from other localities. ${ }^{104} \mathrm{He}$ also reasoned that without the potential for such gifts to exempt institutions, the money would be consumed rather than invested. ${ }^{105}$ Finally, he offered as a practical economic justification that non-productive land did not produce the income to pay any levied taxes, thus no revenue could be exacted. ${ }^{106}$

In the vein of public policy argument, Dr. Eliot posited that tax should only be levied upon commercial activities for private gain, distinguishing these from commercial activities to support public service. ${ }^{107}$ First he argued that property contributed to charity underwent a change in its nature: "the money which built [the institutions] is no longer to be counted as property, in the common sense. It can never again be productive, except for the purposes of the trust for which it was set apart."

Second, he proposed that "churches, colleges, and hospitals serve the highest public ends" shaping the public's character, as opposed to the lower order public services of schools, roads, prison and police. ${ }^{109} \mathrm{He}$ concluded that by consequence of providing for the higher order ends, the charities should be exempt from contributing to the lower order services. ${ }^{110}$

Third, he argued that the exemption contributed to the American policy of freedom from government by "combining liberty with stability in free institutions."111 $\mathrm{He}$ posited that liberty required many municipal centers, allowing citizens to expressly associate independent of government in order to oppose the centralized power of the government. ${ }^{112}$ In contrast to the U.S. situation, he posed that the French government's concentration of all power unto itself led to its people being inexperienced in associated action, and thus their lack of ability to exercise liberty. ${ }^{113}$

104. Id. at 378 .

105. See id.

106. See id. at 389 (presenting the example of a church whose land and building, valued at $\$ 3,000$, would require $\$ 4,500$ to pay the tax beyond its normal operating expenses).

107. See Diamond, supra note 25 , at 24 .

108. ELIOT, supra note 42 , at 369 .

109. Id. at 371,374 . This argument furthered the 1850 s church argument that churches promoted personal morality, public spiritedness, and democratic values. See supra Part V.

110. See ELIOT, supra note 42 , at 371,374 .

111. Id. at 392-93.

112. See id. at 392 .

113. See id. 
In presenting his tax policy justification for what types of income should be taxed, Dr. Eliot sought to draw a distinction between income earned in furtherance of, and ancillary to, a charitable purpose, and other income earned for profit. First, he distinguished unproductive land and gifts from commercial activities. Unproductive land, he argued, is neither owned like ordinary property nor remunerative, and thus should not justly be taxed. ${ }^{114}$ Second, charitable gifts, he argued, are an expression of benevolence not driven by private gain, and benevolence should be favored over self seeking. ${ }^{115}$

Dr. Eliot relinquished two situations in which an institution's property should be taxed. First, he relinquished the issue of tax for accumulated property beyond that required to accomplish the charitable purpose: "No exempted institution can hold real estate free of taxes except that which is fairly necessary for the purposes of the religious, educational or charitable trust." 116 However, as to the issue of limiting the property exemption for such institutions:

If the legislature could tell with certainty just how much property it was expedient for a church, or a college, or a hospital to have, then a limit for exempted property in each case would be natural and right; but the legislature cannot have this knowledge; and if they could acquire it for to-day, it would be outgrown to-morrow. Moreover, the circumstances and functions of the various exempted institutions are so widely different and so changeable, that each institution would necessarily have its own limit prescribed by law, and would be incessantly besieging the legislature for a change in its limit. ${ }^{117}$

Furthering this argument, he proposed that a tax exempt charity held its assets in a public trust for the public's benefit and that the public would not want to limit its ability to benefit from the trust's charitable acts. ${ }^{118}$

114. Id. at 374 .

115. Id.

116. See ELIOT, supra note 42 , at 386.

117. Id. at 387 .

118. See id. at 388; see also supra Part IV (noting that state charters to charitable corporations frequently limited the amount of income or assets). The 1916 Walsh Commission recommended limiting the amount of assets allowed for a foundation. See infra Part VIII. 
Secondly, he relinquished tax exemption for that an institution's income earned with the view toward profit:

It would be dishonorable evasion of the real intent of the statute to claim exemption on real estate which was bought with the intention of selling it again at a profit; and if any addition could be made to the statute that would make such a practice impossible, or would subject it to penalties any institution which should be guilty of it, such and addition would be an improvement .... ${ }^{119}$

However, he separated for profit income from that earned to support the charitable purpose or earned in conducting the business of the charitable purpose, by example a church selling land to support itself, the poor, or to change premises. ${ }^{120}$

As to the argument that the wealthy abused their exempt endowments, Dr. Eliot countered that the wealthy, but not the poor, could live without them:

To prejudice the mass of people against endowments is the part of a demagogue, for it is to induce them to act ignorantly in direct opposition to their own real interests; since endowments exist for the benefit of the great mass of people, while they are a matter of but slight concern to the rich. The rich man does not care whether education be dear or cheap; he does not want the scholarships of college; he does not need to send his children to a hospital; he could afford to keep a clergy man in his own family if he cared to. It is the poor man who needs the church which others have built; the college which, because it has endowments, is able to offer his ambitious son a liberal education; the hospital which can give him, when disabled, attendance as skillful and careful as the rich man can buy. ${ }^{121}$

119. ELIOT, supra note 42, at 386. Not until 1939 did Congress enact the predecessor to the unrelated business income regulations, placing this type of income outside the charitable exemption, thus subjecting it to normal tax. See infra Part IX.

120. See ELIOT, supra note 42 , at 386 .

121. Id. at 385 . The criticism of abuse by the wealthy most strongly played in Congressman Patman's 1960 reports, in which he cited specific examples on a foundationby-foundation basis. See infra Part X. However, the Treasury in its 1965 report concluded that it found very few cases of such abuse. See infra Part XI. Abuse of 
In order to protect against the abuse of an exemption, he proposed judicial scrutiny of the sale of land that could lead to personal inurement, the publication of annual returns, the loss of exemption for institutions that later turn out not to have a public character and the reformation of institutions committing any abuses. ${ }^{122}$

In addressing a criticism that social expenditures decided upon by exempt institutions violated the U.S. concept of representative democracy, Dr. Eliot proposed that charities are better suited for determining and providing public service because they foster self reliance through avoiding the political corruption and divisiveness of centralized government. ${ }^{123}$ In support that government grants lead to a powerful government, he stated:

The exemption method is emphatically an encouragement to public benefactions. On the contrary, the grant method extinguishes public spirit. No private person thinks of contributing to the support of an institution which has once got firmly saddled on the public treasury. The exemption method fosters the public virtues of selfrespect and reliance; the grant method leads straight to an abject dependence upon that superior power-Government. ${ }^{124}$

As to the tax policy criticism that a taxpayer should not be

foundations by wealthy taxpayers formed the pretext justification of the 1943 reporting requirements (infra Part IX(A)), 1950 regulations (infra Part IX(B), and 1969 extensive regulations (infra Part VIII).

122. See ELIOT, supra note 42, at 393-94. Three of Dr. Eliot's proposals found their way into federal legislation. Prohibition against personal inurement, though missing in the first federal charitable tax exemption of 1894, entered in the 1909 Payne-Aldrich Tariff Act . See infra Part VII. Congress enacted an annual foundation reporting requirement in 1943. See infra Part IX. The Internal Revenue Service (I.R.S.) has the authority to strip a non-profit of its exemption for non-compliance with its charitable purpose and the tax regulations. The I.R.S. does not have the authority to reform a nonprofit, which is a matter of the state law in which the non-profit in incorporated.

123. ELIOT, supra note 42 , at 383 . Morris Hillquit, founding member of the American Socialist Party, and Pastor John Haynes Holmes, provided testimony to the 1916 Walsh Commission, refuting this contention. See infra Part VIII. They testified that all expenditure should be subject to government choice because: (1) government contributed to the charitable institution through relinquished tax, and thus had an indistinguishable interest in the endowment; and (2) the wealth that established the foundation derived from the common man's labor. See infra Part VIII.

124. ELIOT, supra note 42, at 383. 
made to support, through the burden of exemption, a charitable institution either not of his choosing or from which he derives no benefit, Dr. Eliot responded that the basis of taxation required that taxpayers support a host of activities, such as public education, though not beneficial to, or the choice of, each taxpayer. ${ }^{125}$ In countering Parton's argument that exemption led to the scattering of more endowments than could be maintained by the community, Dr. Eliot agreed that in such a situation the endowments needed to consolidate. ${ }^{126}$

In dealing with the argument against the dead hand presented by James Madison, Dr. Eliot responded two fold. ${ }^{127}$ First, he contended that the dead hand argument was primarily antagonistic to the Catholic Church, thus a bigoted attempt to discriminate against Catholics that obviated from the principle of legislating toward a particular religion. ${ }^{128}$ Second, though theoretically possible, he saw few circumstances in which an endowment would actually outlive its charitable purpose. ${ }^{129}$ However, he argued that such circumstances of mischievous or outlived endowments could only be investigated when the state granted exemption which in turn granted the state the right of inspection into the endowment's affairs. ${ }^{130}$ Thus, Dr. Eliot postured that the government should require an annual public reporting in exchange for exemption. ${ }^{131}$

\section{The Massachusetts' Decision}

In its decision, the majority of the Massachusetts Commission sided with Dr. Eliot stating:

All gifts, whereby the individual shows any true

125. See id. at 385 .

126. Id.

127. The dead hand concept justified Henry VIIIs enactment of the Statute of Uses' rule against perpetuities, as well as the various enactments of statutes of mortmain. See supra Part III. The dead hand criticism carried forward in every negative committee report on foundations. By example, the 1916 Walsh Commission proffered the dead hand criticism against industrialists establishing perpetual philanthropic foundations that would inevitably manipulate the U.S. educational system to encourage industrialist policy over labor rights policy. See infra Part VIII. Approximately 40 years later in 1954, the Reece Committee proffered that the industrialists' perpetual foundations manipulated the U.S. educational system in favor of socialism. See infra Part IX(D). Each negative report recommended limiting a foundation's life span from a range of 10 years to 40 years.

128. See ELIOT, supra note 42 , at $383-84$.

129. Id. at 384 .

130. Id.

131. See id. As discussed below, Congress enacted an annual foundation-reporting requirement in 1943 . See infra Part IX. 
self-forgetfulness for the public good, will not only be welcomed, but the disposition to make them will be encouraged and fostered by every wise state. As a general rule, all such gifts are in the exact line of what the state seeks to secure by its taxation, and there is really just as great an absurdity in taxing them as there would be in retaxing the taxes themselves. ${ }^{132}$

The Commissioners favored the social policy tack, nearly ignoring Dr. Eliot's tax subsidy justifications. ${ }^{133}$ The Commissioners stated that the goal of social progress, and thus government's role to support, was the relinquishment of selfinterest and private gain in favor of altruism and benevolence toward others. ${ }^{134}$ Charitable gifts and institutions best achieved this goal of relinquishment of self-interest and private gain. Second, in alignment with Dr. Eliot's public policy reasoning, the Commission stated:

Property, which passes out of private hands a freewill offering for public uses, and which loses thereby its entire power of reproducing itself for private gain or emolument, deserves very different treatment, for it must ever stand in a very different relation to the state from that which private parties can still control for private ends. ${ }^{135}$

In turning to the state property tax exemption for mutual insurance companies, the Commission recommended that, absent the historical exemption, equity required eliminating their exemption because as business operations, they were similarly situated to manufacturing and commerce. ${ }^{136}$ Finally, in concluding its report on tax exemption, the Commission called for annual reporting on exempt property. ${ }^{137}$

132. 1874 MASS. REPORT, supra note 86, at 154.

133. See supra Part IV (noting that the Massachusetts constitution directed the legislature and courts to promote in the public the principles of general benevolence, social affections, and generous sentiments).

134. See Diamond, supra note 25, at 27. Dr. Eliot wrote that "[t]o develop noble human character is the end for which States themselves exist. ..." ELIOT, supra note 42, at 371; see also infra Part VIII (in which Samuel Untermyer, a socialist labor attorney and organizer, testifying to the 1916 Walsh Commission, supported this finding as the ultimate justification for maintaining the charitable exemption).

135. 1874 MASS. REPORT, supra note 86, at 154.

136. See id. at 173 .

137. $I d$. at 178 . The reporting would allow the state to continually assess the impact 


\section{E. The Massachusetts' Minority Report}

The Commission's minority report started with the proposition that exemption, which correspondingly required an increase of all other's tax rates, should only be granted in two situations: (1) to institutions, more efficient than the state, that are agents or instrumentalities of the state and (2) to institutions whose activities are not within the scope of the state but in its best interests to maintain regardless of the costs. ${ }^{138}$ In support of the more efficient instrumentality position, the minority argued against exemption but for those institutions "doing the work which but for them the Commonwealth herself must do, and doing it as well and at as little cost as the officers or agents of the government would do it." ${ }^{\text {"139 }}$ The minority posited that the state alone, not charities and individuals, owns the right to provide education, hospice, and for the poor. ${ }^{140}$ Consequently, the state has a right, based on its assessment of the efficiency of the provision of services by an organization, to establish and revoke a state grant of agency and exemption. ${ }^{141}$

Further, the minority stressed that the scope of the exemption must be limited to the resources directly necessary for accomplishing the services, thus allowing tax assessment upon an organization's additional resources such as land. ${ }^{142}$ In this context, an exemption grant should be limited to the value of the property required to be employed, that value taking into consideration the income produced from the exempt property. The state should periodically review the exempt institutions to determine the sufficiency of the property employed, adjusting the value of property exempted pursuant to the need for performing the services. ${ }^{143}$ Answering the argument that constricting the exemption will in turn constrict the institution's resources to carry out its charitable activities, the dissent countered that the increase in taxes upon all other taxpayers thus constricted their ability to pursue their own activities, a countervailing detriment. ${ }^{144}$ The minority concluded that exempt institutions, as organs of the state, report annual returns to the respective state agency responsible for the area of service, such as the board of

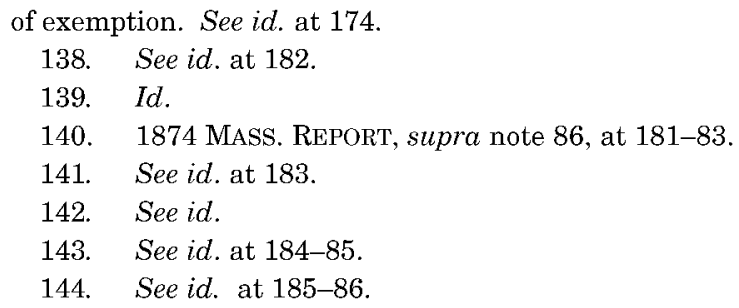


education and board of state charities, so that the agency could assess the provision of services and assess tax upon surplus property. ${ }^{145}$

Regarding religious exemption, the minority observed that, after disestablishment, the church could not be an organ of the state, and thus could not be exempt pursuant to the instrumentality position. ${ }^{146}$ Pursuant to the church's activities filling societal needs beyond the scope of state action, the minority observed that the increasing value of the church property rendered the increasing value of the tax abatement uneconomical in comparison to the benefit of the church to the community. ${ }^{147}$ The minority agreed with Presidents Madison and Grant that, pursuant to contractual equity, the church should contribute for its enjoyment of state services and that pursuant to social-economic equity, an exemption would lead to harmful undue accumulation. ${ }^{148}$ As to the benefits of the church to the state and society, the minority argued that every citizen also serves the state and society, for which the state does not owe compensation. ${ }^{149}$ The minority noted that churches uneconomically employed exempt funds for building expensive temples for festivities, and that the same denomination uneconomically located many churches close together. ${ }^{150}$ While acknowledging that the buildings of the church represented fine art, the minority contended that the beauty of its buildings did not constitute a justification for exemption along the same lines as the teaching of social morality. ${ }^{151}$ Regarding Dr. Eliot's argument that the churches' grand edifices created land value and economy around them, the minority responded that all business' grand buildings attracted the same, but without the corresponding involuntary assessment upon the taxpayers. ${ }^{152}$

145. See id. at 188-89.

146. See 1874 MASS. REPORT, supra note 86 , at 190.

147. See id. at 191-93. The Commission noted that in the U.S. between 1850 and 1870 , churches had grown from 38,061 to 63,082 , with an increase in property value from $\$ 87$ million to $\$ 354$ million. Id. at 192 . In Massachusetts, the number of churches grew from 1,475 to 1,764 during this period, and their property value increased from $\$ 10$ million to $\$ 24$ million. Id. Between 1870 and 1874 , the property value further increased to $\$ 30$ million. Id. at $192-92$

148. See id. at 191-92.

149. See id. at 192. This position is similar to that posited by the Senate Finance Committee in the 1864 Congressional debate, that all activities of goodwill support good government, benefiting each person personally. See supra Part VI.

150. See 1874 MASS. REPORT, supra note 86 , at 194.

151. See id. (according to the minority, "[t]he church was exempted from taxation because of its moral affect upon the community, not that it might become a teacher of the fine arts. . . [e]xemption may be justified by the former of these considerations, not that latter").

152. See id. at 194-95. 
As to arguments based in a historical exemption, the minority replied that the state does not contract with its citizens regarding baseless immunity from taxes but rather provides exemption in exchange for services, and that exemption may be withdrawn at any time. ${ }^{153}$ The minority contended that the church, having enjoyed exemption, had grown strong enough to stand on its own. ${ }^{154}$ However, conceding the societal value of religious institutions in the area of morality and peace, the minority recommended a ceiling threshold for all churches, so that small congregations would not dissolve because of the tax liability. ${ }^{155}$

\section{1890-1900: THE 1864 CONGRESS' FEAR PLAYS OUT ON THE 1894S CONGRESS EXPANDING EXEMPTIONS AND THE SCOPE OF EXEMPTION}

By the 1890s, more institutions received state tax exemptions and for a wider scope of their income generating activities, such as endowments. ${ }^{156}$ The exemptions flourished based on the economic policy justification of the trade off of public service for tax subsidy. ${ }^{157}$ In 1892, the Supreme Court clearly scoped this government-benefit policy in line with that enunciated by Dr. Eliot in $1875{ }^{158}$ According to the Court:

A grant of exemption is never to be considered as a mere gratuity - a simple gift from the legislature. No such intent to throw away the revenues of the State, or to create arbitrary discriminations between the holders of property, can be imputed. A consideration is presumed to exist. The recipient of the exemption may be supposed to be doing part of the work which the State would otherwise be under obligations to do. A college, or an academy, furnishes education to the young, which it is a part of the State's duty to furnish. ${ }^{159}$

As to the tax subsidy element of this policy, it stated:

153. See id. at 196.

154. See id. at 197.

155. See id. at 197-99.

156. See Diamond, supra note 25, at 32.

157. See id. at $32-34$.

158. See supra part VI(C) (discussing Dr. Eliot's government-benefit analysis).

159. Illinois Cent. R.R. Co. v. Decatur, 147 U.S. 190, 201 (1893). 
In a general way it may be said that the probable amount of future taxes can be estimated. While of course no mathematical certainty exists, yet there is a reasonable uniformity in the expenses of the government, so that there can be in advance an approximation of what is given when an exemption from taxation is granted .... ${ }^{160}$

Further, the Court maintained the public policy rationale that charitable institutions produced a public good, perhaps not quantifiable, in line with Dr. Eliot's proposed justification that exempt organizations served the highest public ends, ${ }^{161}$ stating: "Or the recipient may be doing a work which adds to the material prosperity or elevates the moral character of the people; [such as] ... churches and charitable institutions, because they tend to a better order of society. (emphasis added)"162

In 1894, at the instigation of Congressman Woodrow Wilson, Congress enacted the income tax, imposing a two percent tax on "net profits or income above actual operating and business expenses ... of all ... corporations, companies, or associations doing business for profit." ${ }^{, 163}$ Though having categorically rejected the proposition thirty years earlier, Congress included the first federal tax statute exempting charitable associations from taxation: "Nothing herein contained shall apply... to corporations, companies, or associations organized and conducted solely for charitable, religious, or educational purposes . . .".164

In exempting charitable associations from the application of the Act, the provision also exempted their endowment income. Congress rationalized that charitable institutions provided desirable public purposes, thus justifying the exemption. ${ }^{165}$

The general topic of exemptions from income tax was fiercely debated in the Senate. However, the debate focused on who was to receive exemption, not on whether any exemptions should be

160. Id. at 202 .

161. See supra part VI(C).

162. Illinois Cent. R.R.. Co., 147 U.S. at 201.

163. Boris I. Bittker \& George K. Rahdert, The Exemption of Nonprofit Organizations from Federal Income Taxation, 85 YALE L.J. 299, 302 (1976).

164. See Mark Rambler, Note, Best Supporting Actor: Refining The 509(A)(3) Type 3 Charitable Organization, 51 DUKE L.J. 1367, $1370 \mathrm{n} .16$ (2002) (noting that the income tax sections of the Tariff Act were later found unconstitutional by the Supreme Court in Pollock v. Farmers' Loan \& Trust Co., 158 U.S. 601, 637 (1895)).

165. See Charles O. Galvin \& Neal Devins, A Tax Policy Analysis of Bob Jones Univ. v. United States, 36 VAND. L. REV 1353, 1365 (1983) (stating that Congress clearly justified the Tariff Act's tax exemption for charitable, religious, or educational organizations on the basis that such organizations served a desirable public purpose). 
included. ${ }^{166}$ By example, the bill included a personal exemption from tax for the first four thousand dollars of income. ${ }^{167}$ In response to this exemption, Senator Hill, New York, stated:

If there must be an income tax, it should be substantially uniform and consistent, and should tax all incomes or none at all... . There should be no favoritism, no discriminations, no privileged classes. If a tax upon industry, thrift, and earnings is defensible at all, then all exemptions are matters of governmental charity and must necessarily be very limited and reasonable. ${ }^{168}$

As forecast by the 1864 congressional reason for denying exemption that "every effort would be made to bring cases within the principle," a number of other non-charitable but nonprofit mutual organizations, including fraternal beneficiary societies operating upon the lodge system that provided life, sick, accident, and other insurance, and building and loan associations, received tax exemption. ${ }^{169}$ Lobbying played the key role in the extension of these exemptions. ${ }^{170}$

In an about turn from his opening statement on the inequity of exemptions, Senator Hill shortly thereafter lobbied for exemptions for mutual saving banks and mutual life insurance companies. ${ }^{171}$ In arguing for a privileged exemption for mutual saving banks, he stated: "Argument ought not be necessary to sustain the proposition that mutual savings banks should be absolutely exempt from any income taxation. They represent the savings of the poor; they are not established for ordinary business purposes.... "172 $\mathrm{He}$ ended his argument in favor of exempting mutual savings banks with: "This Government can not afford to permit the savings of the poor to be taxed through a Federal income tax."

166. By example, potential exemptions included an exemption from tax for the income of government employees and for homesteads. See 26 CONG. REC 6629 (1894) (statement of Sen. Hoar).

167. 26 CONG. REC. 6620.

168. Id. (statement of Sen. Hill). The Massachusetts Minority Report stated nearly this reasoning. See supra part VI(E). As examined below, Senator Hill then proceeded to lobby for exemptions that would benefit the businesses in his state, New York.

169. Diamond, supra note 25 , at 36 .

170. See id. at 36 n.85.

171. See 26 CONG. REC. 6622-23 (1894) (statement of Sen. Hill).

172. Id.

173. Id. 
Senator Peffer, Kansas, retorted to Senator Hill that it was inequitable that his constituency, the agricultural states, should bear a burden of tax different than the North:

The point to be made is that because wealth is accumulated in New York, and not because those men are more industrious than we are ... but because they trade ... buy and sell ... deal in usury, because they reap in what they never earn ... take in and live off what other men earn, they shall be exempt from taxation, and that we who are hewing wood and carrying water shall continue to bear the burdens of the Government. ${ }^{174}$

Senator Higgins argued that exemptions "would be the disposition on the part of one section of the country to impose the burden of taxation upon the other, that they might thereby escape themselves."175

Lobbying for the exemption of mutual life insurance companies, Senator Hill proposed:

The same excellent reasons why mutual savings banks should be exempted from this tax apply with full force to mutual life insurance companies.... Life insurance, when conducted as a business for gain, has no more claim than any other business to exemption from taxation. ... But life insurance by the head of a family for the protection of his family ought not be taxed. This is a fundamental principle of public economy and public policy which has not been directly questioned by any high authority. ${ }^{176}$

Senator Hill offered two tax policy justifications and a political one for the exemption, thus encouragement, of mutual insurance. As with mutual savings banks, he argued that that the income tax applied to profits, whereas the mutual did not operate for profit. ${ }^{177}$ Second, he pointed out that the growth of the insurance fund required the premiums to be invested in the stocks of companies that were themselves subject to the income

174. 26 CONG. REC. 6634 (statement of Sen. Peffer).

175. 26 CONG. REC. 6627 (statement of Sen. Higgins).

176. 26 CONG. REC. 6623 (statement of Sen. Hill).

177. See 26 CONG. REC. 6623 (statement of Sen. Hill); Diamond, supra note 25, at 37. 
tax. ${ }^{178}$ Consequentially, he argued, the mutual insurance company's investment income had already been taxed, and without exemption the same income would be taxed again. Worse yet, he pointed out that the present language of the bill could be interpreted to tax the death benefits, thus three levels of taxation on the income. Politically, he argued that the mutual operated in the interest of the public by protecting the surviving family from pauperism. ${ }^{179}$

In support of the exemption for fraternal organizations, mutual insurance companies and mutual savings banks, Senator Patton argued that any tax burden would only be passed onto the consumer in rising insurance costs, reduced earnings from the savings accounts, and finally, reduced insurance death benefit to the surviving family. ${ }^{180}$

Senator Platt, Connecticut, carried the above arguments for exemption to the extreme. He analogized that if the above exemptions were granted based on the justification of assisting the common man, that then joint stock companies should also be exempt from tax. ${ }^{181}$ He compared joint stock companies to mutual companies, both operating as partnerships rather than businesses, with small capitalization and with their members consisting of the common employees. ${ }^{182} \mathrm{He}$ argued that the contemplated four thousand dollar personal tax exemption discriminated in favor of proprietorships over joint stock companies to the detriment of the employees. ${ }^{183}$ He reasoned that only joint stock companies allow employees to retire because only the joint stock allowed the retiring employee to extract capital by selling to the other employees or a new member. ${ }^{184}$

The Congress enacted the exemptions for fraternal societies providing members insurance, building and loan associations, and mutual savings banks. ${ }^{185}$ Congress did not directly address the subject of the charitable deduction. Senator Platt addressed the concept of charitable deduction in passing, noting that "[the Act] makes a man pay a tax not only on the premiums which he pays to keep up his life insurance for the benefit of his family, but upon all that he gives to charitable objects." ${ }^{\text {"186 }}$ Further,

178. See 26 CONG. REC. 6623 (1894) (statement of Sen. Hill).

179. See id. (statement of Sen. Hill).

180. See 26 CONG. REC. 6697 (statement of Sen. Patton).

181. See 26 CONG. REC. 6704 (statement of Sen. Platt).

182. See 26 CONG. REC. 6704-05 (statement of Sen. Platt).

183. See 26 CONG. REC. 6705 (statement of Sen. Platt).

184. See 26 CONG. REC. 6705 (statement of Sen. Platt).

185. Diamond, supra note 25 , at 36 .

186. 26 CONG. REC. 6706 (1894) (statement of Sen. Platt). 
Senator Hoar, in addressing the issue of whether citizens should be taxed though residing abroad, expressed a trade-off between charitable contribution and taxation:

So, if an American citizen went abroad and carried the protection of his country, of his citizenship with him, he did not escape its burdens. There are a great many people... who go abroad for that very purpose .... they had none of the voluntary obligations which rest upon citizens, of charity, or contributions, or supporting churches, or anything of that sort, and they escaped taxation. ${ }^{187}$

The 1909 Payne Aldrich Tariff Act continued the exemption, legislating the charitable exception from application of the corporate excise tax. Notably, Congress added the restriction against private inurement: "any corporation or association organized and operated exclusively for religious, charitable, or educational purposes, no part of the net income of which inures to the benefit of any private stockholder or individual."(emphasis added). ${ }^{188}$ Congress did not interpret nonprofit as either nonbusiness or non-surplus generating. ${ }^{189}$ On the contrary, Congress and the Supreme Court adopted Dr. Eliot's argument that tax should only be levied upon commercial activities for private gain versus those for public service. The 1924 Supreme Court held:

Two matters apparent on the face of the [excepting] clause go far towards settling its meaning. First, it recognizes that a corporation may be organized and operated exclusively for religious, charitable, scientific or educational purposes, and yet have a net income. Next, it says nothing about the source of the income, but makes the destination the ultimate test of exemption.

Evidently the exemption is made in recognition of the benefit which the public derives from corporate activities of the class named, and is intended to aid them when not conducted for private gain. Such activities cannot be carried on without money; and

187. 26 CONG. REC. 6632-33 (statement of Sen. Hoar).

188. Tariff Act of 1909, ch. 6, 38, 36 Stat. 11, 112-13 (1909).

189. See Brody, supra note 56, at 605-06. 
it is common knowledge that they are largely carried on with income received from properties dedicated to their pursuit. This is particularly true of many charitable, scientific and educational corporations and is measurably true of some religious corporations. Making such properties productive to the end that the income may be thus used does not alter or enlarge the purposes for which the corporation is created and conducted. ${ }^{190}$

The federal policy that destination of income trumped source of income expanded the historical scope of exemption derived from the states' policies that merely granted limited, albeit expanding, tax exemption to churches and educational institutions. ${ }^{191}$ Dr. Eliot stated that exemption policy was not intended to cover activities established to generate profit, distinguishing them from those conducted in the business of the charitable purpose. ${ }^{192}$ This federal divergence from historical state policy continued until the enactment of the tax on unrelated business income.

\section{1900-1940: THE RISE OF THE INDUSTRIALIST PRIVATE Foundation, THE (IGNORED) POPULIST RESPONSE OF THE WALSH COMMITTEE}

The accumulated industrialist wealth of the late nineteenth century U.S. industrial revolution ushered in the next phase of the charitable institution, the private foundation. ${ }^{193}$ Before the

190. Trinidad v. Sagrada Orden de Predicadores de la Provincia del Santisimo Roasrio de Filipinas, 263 U.S. 578, 581 (1924). The Court upheld this interpretation until the enactment of the tax on unrelated business income. See C.F. Mueller Co. v. Comm'r, 190 F.2d 120, 121-22 (3d Cir. 1951). In C.F. Mueller Co., the court stated:

[T] he statute lends itself to the result so far achieved... since it plainly contemplates that there may exist income otherwise taxable and does not proscribe any particular source of income.... The policy ... is that the benefit from revenue is outweighed by the benefit to the general public welfare gained through the encouragement of charity.... This point of view has predominated through the more than thirty years. ...

$190 \mathrm{~F} .2 \mathrm{~d}$ at $121-22$.

191. See supra Part V.

192. See supra Part VI(C).

193. See Marsh, supra note 10, at 142-43. The various commissions, congressional committees, and government reports from 1916 thereon, discussed herein, focus on the philanthropic, private foundation. Congress did not codify a formal "private" foundation definition until 1969, but beginning in 1943 enacted legislation treating the philanthropists' class of foundations differently from traditionally publicly supported institutions. This evolution of different treatment is thoroughly explored infra. 
twentieth century, only five foundations had been established, ${ }^{194}$ whereas over sixty foundations were recorded by $1910 .{ }^{195}$ By 1913, three industrialists, Russell Sage, ${ }^{196}$ Andrew Carnegie, ${ }^{197}$ and John D. Rockefeller, ${ }^{198}$ from their personal wealth established foundations whose purpose was to promote their particular philanthropic vision for society. ${ }^{199}$ Carnegie and Rockefeller's

194. Marsh, supra note 10 , at 143 .

195. Crimm, supra note 3, at 780. However, as Professor Crimm notes, there is some disagreement over the number of foundations established before 1910 . See id. at 780 n. 157 .

196. See Crimm, supra note 32, at 1103 (noting that Mrs. Sage is credited with establishing the first modern foundation, in the name of her husband, being an "openended endowment devoted to self-defined goals of reforming the public's social, economic, and political existence; vesting broad discretion in trustees; and relying on a professional staff to identify private institutions deserving of grant funds."). The Russell Sage Foundation's 1907 Letter of Gift from Margaret Olivia Sage states:

I have transferred to Russell Sage Foundation... a fund, the principal of which ... shall be held, and the income thereof applied to the improvement of social and living conditions in the United States of America ....

The scope of the Foundation is not only national but is broad. It should, however, preferably not undertake to do that which is now being done or is likely to be effectively done by other individuals or by other agencies. It should be its aim to take up the larger and more difficult problems, and to take them up so far as possible in such a manner as to secure co-operation and aid in their solution ....

Letter of Gift, at http://www.russellsage.org/about/letter_of_gift.shtml (last visited July 1, 2003).

197. Andrew Carnegie donated $\$ 350,000,000$ to a variety of personal foundations and charity, including the Carnegie Institute of Pittsburgh, founded in 1896, the Carnegie Institution of Washington, founded in 1902, the Carnegie Endowment for International Peace, founded in 1910, and the Carnegie Corporation of New York, founded in 1911, amongst several others. Andrew Carnegie, at http://econ161.berkeley.edu/TCEH/

andrewcarnegie.html (last visited July 1, 2003). While Carnegie established many foundations, it has been argued that he was not the first to do so. See Crimm, supra note 32, at 1102-04 (stating that although Andrew Carnegie's essay the Gospel of Wealth established the intellectual vision for the industrialist's philanthropy, he cannot be credited with establishing the first philanthropic personal foundation). However, as Professor Crimm notes, it was Carnegie's founding of the open ended Carnegie Corporation of New York, four years after Mrs. Sage's gift to the Russell Sage Foundation, that marks his establishment of an industrialist foundation. See id. at 1103-04.

198. John D. Rockefeller began making philanthropic donations in 1889 , beginning with gifts to found the University of Chicago, and later went on to establish the Rockefeller Institute for Medical Research, founded 1901, and the Rockefeller Sanitary Commission, founded 1909. A History: Introduction, at http://www.rockfound.org/ Documents/180/intro.html (last visited July 1, 2003). Also in 1909, he established the trust for the Rockefeller Foundation, but was denied a federal charter. Id. Finally, in 1913 the State Legislature of New York chartered the foundation. Id. In 1913 and 1914, he donated one hundred million to his foundation. A History: Timeline, at http:// www.rockfound.org/Documents/180/1913.html (last visited July 1, 2003).

199. See Marsh, supra note 10, at 142-43; Crimm, supra note 3, at 780 (discussing the establishment of the Carnegie Institute of Pittsburgh, the Carnegie Institute for Technology, the Carnegie Endowment for International Peace, and the Russell Sage Foundation). 
philanthropic vision held that social ills could be relieved through funding business-like institutions that employed skilled professional staff and undertook scientific research to produce tangible results. ${ }^{200}$ This foundational model created the philanthropic policy of the many foundations to follow in the early twentieth century, such as Kellogg and Lilly. ${ }^{201}$

This new type of philanthropic foundation attracted critics in the vein of James Parton, but with the Church focus replaced with an industrialist focus. ${ }^{202}$ Both 1912 Republican platform presidential candidates, William Taft and Theodore Roosevelt (Progressive Republicans), opposed the establishment of such industrialist foundations on the premise that their charitable nature should not be used to justify the nature of the production of the income, the industrialists' greed. ${ }^{203}$ The populist opinion against the industrial class' method of income accumulation had been expressed by Parton in 1873 and again during the debates upon the 1894 Tariff Act. Senator Peffer summed up the populist sentiment:

Mr. President, I have said several times in this
presence that no man ever earned a million dollars
a year, and I will say that no man ever earned a
million dollars in a lifetime. Whenever men begin
to grow rich rapidly they are doing it because they

200. See Marsh, supra note 10 , at 143.

201. See id. Other well-known Foundations establish around this time period included Julius Rosenwald Fund (1917), Commonwealth Fund (1918), Twentieth Century Fund (1919), Guggenheim Foundation (1929), and W.K. Kellogg Foundation (1930).

202. See Crimm, supra note 32, at 1104. Dr. Charles Eliot served on the board of the Rockefeller Foundation. Margaret Miller, A GUIDE TO SELECTED FILES OF THE Professional PaPers of Simon Flexner at the Americal PhILosophical Society, $a t$ http://www.amphilsoc.org/library/guides/flexner/flextext.htm (last visited Mar. 10, 2004).

203. See Brody, supra note 11, at 923; Crimm, supra note 32, at 1104 n.58. Quoting from Tax-Exempt Foundations and Charitable Trusts: Their Impact on Our Economy, Chairman's Report, House Select Committee on Small Business, Committee Prints, Cong. Sess.: 87-2, Dec. 31, 1962 at Letter of Transmittal p. (v), President Theodore Roosevelt wrote in 1908 that "The only way to counteract the movement in which these men have been engaged is to make clear to the public what they have done in the past and just what they are seeking to accomplish in the future." Ironically, though Theodore Roosevelt openly attacked the industrial trusts in the early twentieth century, he sat as a trustee for the Peabody Education Fund, established in 1867 by the financier George Peabody with a contribution of two million dollars. See James Allen Smith, Private Foundations and Policy Making, paper presentation, A Forum on Philanthropy, Public Policy and The Economy, May 13-14, 2002, University of Southern California, at http://www.usc.edu/schools/sppd/philanthropy/forum2002/papers/smith_paper.pdf (last visited July 5, 2003). The fund's purpose was to assist in reconciliation between the Northern and Southern states after the War and supported public education in the South. See $i d$. The fund's grants were specifically directed at influencing policy decisions. See id. 
are using the wealth other men create. ${ }^{204}$

The election's winner, William Howard Taft, a social progressive Republican, requested Congress to form a Commission on Industrial Relations to investigate the accumulation of the industrialists' wealth, including their establishment and use of philanthropic foundations. ${ }^{205}$ President Wilson appointed Frank Walsh, the pro-organized labor, Kansas City newspaper editor and attorney as the chairman of the Commission (hereinafter referred to as the "Walsh Commission"). ${ }^{206}$

While the Commission's investigation is credited with providing the backbone of the many negative Congressional and Treasury Reports in the coming decades, the foundations' defenders' testimony also provided the policy reasons for their continuance and the backbone of the positive findings of the future Treasury Reports. Primary arguments both for and against the foundations are exemplified in the following testimony.

Samuel Untermyer, a socialist attorney representing organized labor, in support of the federalization of foundations' charters to contain severe restrictions eventually recommended by the Commission, stated that "the organization of the Rockefeller, Carnegie, Sage, and other similar foundations is a fair illustration of the vice of the system." ${ }^{207}$ However, he continued that he did not share the fear and distrust of the Commission toward foundations. Surprisingly, he felt the establishment of the foundations exemplified the "unselfish public spirit," the ultimate justification in maintaining charitable tax exemptions employed by the Massachusetts Commission. ${ }^{208}$ He further found that the foundation's managers represented a

204. 26 Cong. REC. 6635 (1894) (statement of Sen. Peffer).

205. See Crimm, supra note 32, at 1104. The Commission on Industrial Relations was created by an Act of August 23, 1912. Over three years the populist commission held hearings on a wide number of subjects, primarily focusing upon the mistreatment of labor caused by the industrialists' economic feudalism. The final report consisted of eleven volumes of over eleven thousand pages of which the hearings on the subject of foundations required over one thousand pages. See generally STAFF OF SENATE COMM. ON INDUS. RELATIONS, 64TH CONG., INDUSTRIAL RELATIONS: FINAL REPORT AND TESTIMONY SubmitTed TO Congress 81-86, 220-21, 7427-8013, 8015-8480 (Comm. Print 1916) [hereinafter WALSH COMM.].

206. Frank Walsh became the General Counsel to the Iron Workers Union, serving from 1918 until his death in 1939. A History of the Iron Workers Union: The Depression and a New Deal for Labor 1930-1940, at http://geocities.com/ironworkers373/ iwhistory6d.html.

207. WALSH COMM., supra note 205, at 7430-31.

208. Id. 
higher intellect than possible from government, and that their public works outweighed the founders' "devious" methods of wealth accumulation. ${ }^{209}$ Finally, he suggested that the founders' influence would die off with the founder.

Furthering Untermyer's finding concerning the intellect of foundations' managers, George Perkins, a director of U.S. Steel and International Harvester, stated that the foundations provided efficient management of their resources whereas the government acted oppositely. ${ }^{210}$ He posited that "[t]he function of Government should not be to manage, but to regulate and control management." ${ }^{211}$ Finally, he proposed that public reporting of the foundations' activities in the minutest detail would address the Commission's concerns (this position being reiterated by several of the foundations' supporters). ${ }^{212}$ Dr. Eliot, in defense of interlocking foundation board, stated that such cross board membership created efficiency for the foundations' operations. ${ }^{213}$ Also, he found that the most efficient board members were those with the widest experience who should continue to be employed in constant service to the community. ${ }^{214}$

To Chairman Walsh's question "Why should not foundations be taxed?" John D. Rockefeller Jr. responded that the funds should be left as large as possible to continue to make the substantial contributions to the wealth of the community in which they operated. ${ }^{215} \quad$ Further on this issue, A. Barton Hepburn, Chairman of Chase National bank, stated "The theory upon which all property of that character is exempt from taxation is that it is doing a public service, and the public good it might do would be impaired to the extent of the taxation." ${ }^{216}$

Morris Hillquit, a labor attorney and one of the three founders of the American Socialist Party, put forward two significant arguments against foundations. First, the

209. This position contrasted the position of Samuel Gompers, President of the American Federation of Labor, who said that "I do not think that the Government of our country or that the people of our country are ready to surrender the function of teaching to a private institution such as the Rockefeller Foundation, with the history behind that foundation - the means by which their moneys were first made and later accumulated." Id. at 7647 .

210. Id. at 7599 .

211. Id.

212. Id. at 7599; see also id. at 7857, 59-60 (John D. Rockefeller Jr.'s testimony); see also id. at 8296 (Andrew Carnegie's testimony).

213. Id. at 7965 .

214. Id.

215. Id. at 7858; see supra Part VI(C) for Dr. Eliot's identical argument.

216. WALSH CoMm., supra note 205, at 8257; see supra Part VI(C) for Dr. Eliot's identical argument. 
foundations were not organized for charitable purposes but rather as instruments of the industrialists to improve the economic efficiency of the workers. ${ }^{217} \mathrm{He}$ concluded, from his examination of the testimony of John Rockefeller Jr., and of the expenditure of foundational resources for social studies and the global eradication of disease, that

... we have reached this stage that the welfare of the American worker is no more as important to the American capitalist as is the well-being and economic efficiency of the worker or of the population in foreign undeveloped countries, for we can not sell more commodities to our own population, which is deprived of the means to purchase, so we must undertake to sell them or exchange them for other commodities in the foreign countries. ${ }^{218}$

Regarding foundations support of higher education: “ . . the actual object of this educational work ... is not to in any way elevate the general intellectual condition of the people ...; but it is to train a sufficient and efficient corps of workers, of helpers, of assistants, in the great industrial establishments." ${ }^{219}$ Finally, in objecting to tax exemption, he argued that the government has an interest in the Rockefeller Foundation because the government's contribution represents two million dollars a year in relinquished taxes, for which the public must make up the difference. ${ }^{220}$ Also arguing against tax exemption, Pastor John Haynes Holmes, evolving Senator Peffer's 1894 populist argument, testified that the foundations were established from wealth earned from the common man's labor, and thus government should democratically decide where the foundation's resources should be spent. ${ }^{221}$

Henry Ford testified that he was opposed to charity and philanthropy, employing the Jacksonian liberal position enunciated by Parton, because it weakened the self-reliant spirit of men. ${ }^{222}$ His publicly stated beliefs against charity and

217. WALSH COMM., supra note 205, at 8265-66; see supra Part VI(B) for James

Parton's critique that the philanthropists lacked the charitable motive of altruism.

218. WALSH COMM., supra note 205 , at $8265-67$.

219. Id. at 8268 .

220. Id. at $8274-75$.

221. Id. at 7916-17.

222. Id. at 7630 . 
philanthropy haunted his heirs in that his 1947 establishment of the Ford Foundation led to the charge by Treasury Secretary John Snyder that the "abuse of tax exemption involves the establishment of so-called charitable foundations or trusts which serve as a cloak for controlling businesses." 223

In 1916, the Walsh Commission's congressional final report section on foundations first noted that the Rockefeller and Carnegie Foundations' assets of over two hundred fifty million dollars earned annually more than thirteen million five hundred thousand dollars, being more than twice the federal appropriations for education and social services. ${ }^{224}$ Second, the Commission found that the foundations were manipulating educational and thus social policy. ${ }^{225}$ Presented in support of this finding, some universities had severed their religious affiliation in order to receive grants from Carnegie's foundations. ${ }^{226}$ Also, the Commission received testimony from two professors that, because of their support of the labor movement, their institutions fired them. ${ }^{227}$

The Commission's conclusions were:

12. The domination of men in whose hands the final control for a large part of American industry rests is not limited to their employees, but is being rapidly extended to control the education and "social services" of the Nation.

13. This control is being extended largely through the creation of enormous privately managed funds for indefinite purposes hereinafter designated "foundations" by the endowment of colleges and universities, by the creation of funds for the pensioning of teachers, by contributions to private charities, as well as through controlling or influencing the public press ....

\section{The funds of these foundations are exempt}

223. Revenue Revisions of 1950: Hearings on H.R. 8920 Before the House Committee on Ways and Means, February 3, 1950, 81st Cong., 2d Sess. 19 (1950) (Statement by Hon. John W. Snyder, Secretary of the Treasury); see infra Part X(A).

224. WALSH COMM., supra note 205, at 81.

225. See id. at 84. James Madison, Ulysses Grant, and James Parton foreshadowed this finding that the accumulation of exempt institutions' assets would provide such capital as to influence, if not threaten, democratic institutions. See supra Part VI(B).

226. See Walsh Comm., supra note 205, at 84 .

227. See id. 
from taxation, yet during the lives of the founders are subject to their dictation for any purpose other than commercial profit....

18. The funds of the foundations represent largely the results either of the exploitation of American workers through the payment of low wages or of the exploitation of the American public through the exaction of high prices. The funds, therefore, by every right belong to the American people. ${ }^{228}$ ...

As regards the "foundations" created for unlimited general purposes and endowed with enormous resources, their ultimate possibilities are so grave a menace, not only as regards their own activities and influence but also the benumbing effect which they have on private citizens and public bodies, that if they could be clearly differentiated from other forms of voluntary altruistic effort it would be desirable to recommend their abolition. ${ }^{229}$

The Commission determined that the industrialists' foundations could not be workably differentiated from general public charities. ${ }^{230}$ Thus, the Commission recommended, pursuant to those suggested by Untermyer, a federal charter for all foundations with assets over one million dollars and more than one function. ${ }^{231}$ Further, the charter's constitution should define the allowable acts, limit the assets and the accumulation of unexpended income, as well as provide for strict government scrutiny over the investments while requiring published reports. ${ }^{232}$ In seeking to perhaps perpetuate its existence, the Commission suggested a continuing investigation of all "endowed institutions" exceeding a moderate amount of either assets or income, including religious ones. ${ }^{233}$ Finally, the Commission stated that the federal government should balance the power of foundations by appropriating for education and social services. ${ }^{234}$

228. Id. at $81-82$.

229. Id. at 85 .

230. See id.

231. See id.

232. See id. at 85. The Minority Report to the Massachusetts Tax Commission called for these same restrictions and regulations. See supra Part VI(E).

233. See Walsh Comm., supra note 205, at 85.

234. Id. at 86 . 


\section{1913-1940: THE EXPANSION OF EXEMPTIONS, CONTRACTION OF EXEMPTION'S SCOPE, AND THE INITIATION OF THE Charitable DeduCTION}

During the investigation by the Walsh Commission, Congress enacted the income tax in 1913 in which it maintained the charitable associations' exemption from tax. ${ }^{235}$ As in 1894, the exemption's scope was expanded, this time to cover scientific and benevolent organizations. ${ }^{236}$ Congress again debated the inclusion of mutual companies, using similar arguments as 1894. ${ }^{237}$ However, the Act's author, Representative Cordell Hull, argued that explicitly expanding the exemption coverage was superfluous in that the exemption was already understood to apply to all non-profit making organizations: “. . . any kind of society or corporation that is not doing business for profit and not acquiring profit would not come within the meaning of the taxing clause . ..."238

Treasury, perhaps because Congress did explicitly include additional types of exempt organizations, treated the list as exclusive. ${ }^{239}$ Consequently, in 1916 at Treasury's request, Congress expanded the scope of the exempt clause, in order to prevent economic waste by the Treasury. ${ }^{240}$ In 1918 and 1921, Congress further expanded the scope to include societies for the prevention of cruelty to animals or children and for literary purposes. ${ }^{241}$

In the 1913 Act, Congress rejected, without debate, inclusion of a deduction for charitable contribution. ${ }^{242}$ Congressman Rogers presented the amendment, arguing that lack of the charitable deduction penalized the benevolent community, thus curtailing its contributions. ${ }^{243}$ However, just four years later, even after the Commission on Industrial Relations' final report and

235. Crimm, supra note 27, at $\mathrm{n} .4$ at 4422 n.4 (noting that Congress expanded the exemption to include "any corporation or association organized and operated exclusively for religious, charitable, scientific, or educational purposes.").

236. See H.R. REP. No. 64-92, 64 $4^{\text {th }}$ Cong., $1^{\text {sh }}$ Sess. 4 (1916); see also Bittker \& Rahdert, supra note 163 , at 303.

237. 26 CONG.REC. 1260 (1894) (statement of Rep. Goulden).

238. See Bittker \& Rahdert, supra note 163, at 303 n.11 (noting that Congressman Hull's argument had strength in that the 1909 Act implicitly exempted building and loan associations and fraternal societies if operated not-for-profit).

239. See id. at 303 .

240. See id.

241. Laurens Williams \& Donald V. Moorehead, An Analysis of the Federal Tax Distinction, in 4 Research Papers Sponsored by the Commission on Private Philanthropy and Public Needs 2099, 2100 (1977) (summarizing the Revenue Act of 1950).

242. See 50 ConG. REc. 1259 (1913); Rambler, supra note 164, at 1370.

243. 62 CONG.REC. 1259 (May 6, 1913) (statement of Rep. Rogers). 
recommendations, in the War Income Tax Revenue Act of 1917 Congress enacted the charitable deduction, as follows:

Contributions or gifts actually made within the year to corporations or associations organized and operated exclusively for religious, charitable, scientific, or educational purposes, or to societies for the prevention of cruelty to children or animals, no part of the net income of which inures to the benefit of any private stockholder or individual, to an amount not in excess of fifteen per centum of the taxpayer's taxable net income as computed without the benefit of this paragraph. Such contributions or gifts shall be allowable as deductions only if verified under rules and regulations prescribed by the Commissioner of Internal Revenue, with the approval of the Secretary of the Treasury. ${ }^{244}$

The 1917 Congressional Record reflects that the allowance of the charitable deduction up to fifteen percent of the taxable net income was supported for three different policy reasons. ${ }^{245}$ First, Congress wanted to mitigate the effects of the new high income tax rate on charitable giving. ${ }^{246}$ Senator Hollis, the amendment's author, cited the fact that educational institutions would require significant contributions to survive the war period because the draft reduced the student population. ${ }^{247} \mathrm{He}$ stated that the charitable deduction was required to support educational institutions because: "Now, when war comes and we impose these very heavy taxes on incomes, that will be the first place where the wealthy men will be tempted to economize, namely, in

244. The War Income Tax Revenue Act of 1917, ch. 63, 1201(2); see Rambler, supra note 164 , at 1370 .

245. Senator Hollis introduced the amendment with a twenty percent potential deduction. See 65 CONG. REC. 6728 (1917).

246. Richard P. Davies, Flat Tax Without Bumpy Philanthropy: Decreasing the Impact of a "Low, Single Rate" on Individual Charitable Contributions, 70 S. CAL. L. REV. 1749, 1762 (1997) (citing Senate Comm. on the Budget, Tax Expenditures: Compendium of Background Material on Individual Provisions (1994), reprinted in 11 ExEMPT ORG. TAX REV. 527, 536 (1995). The maximum tax rate was 15\%. Ellen P. Aprill, Churches, Politics, and the Charitable Contribution Deduction, 42 B.C. L. REV. 843, 849 (20002001); see Note, The Charitable Corporation, 64 HARV. L. REV. 1168 n.1 (1951) (stating that the growth of contributions to charities from 1929 's $\$ 1,206$ billion to 1949 's $\$ 4,032$ billion may be attributable to the charitable deduction and a backlash against government's expanding welfare role).

247. See 65 CONG. REC. 6728. 
donations to charity." ${ }^{248}$

Using the government benefit policy argument, he further argued that encouraging charitable contributions allowed a lower tax rate. If charitable giving decreased, thus expenditure on charitable programs, then Congress would have to replace the charitable expenditure with government expenditure which would in turn require higher tax rates. ${ }^{249}$ Also, he argued that charitable giving produced greater economic and welfare benefit to society than taxation:

For every dollars a man contributes for these public charities, educational scientific, or otherwise, the public gets 100 per cent; it is all devoted to that purpose. If it were undertaken to support these institutions through the Federal Government or local governments and the taxes were imposed for the amount, they would only get the percentage, 5 per cent, 10 per cent, 20 per cent, or 40 per cent, as the case may be. Instead of the full amount, they would get a third or a quarter or a fifth." ${ }^{250}$

Senator Hollis presented published editorials, in support of his amendment, which presented further arguments. First, Congress should not tax that charitable part of income given "voluntarily to the public good." Secondly, charitable gifts should not be treated less than business losses for which deduction was allowed. ${ }^{252}$ Thirdly, without the deduction, the taxpayer passed the tax liability, by withholding the tax payment from the charitable donation, onto the charity. ${ }^{253}$ Thus, the lack of deduction undermined the policy of tax exempt status. ${ }^{254}$

248. See 65 CONG. REC. 6728 (statement of Sen. Hollis).

249. John A Wallace \& Robert W. Fischer, The Charitable Deduction Under Section 170 of the Internal Revenue Code, in 4 Research Papers Sponsored by the Commission on Private Philanthropy and Public Needs 2131; see supra Part VI(C) (discussing same justification as enunciated by Dr. Eliot).

250. 65 CONG. REC. 6728 (statement of Sen. Hollis).

251. "From the Washington Post August 25, 1917", Senate, 65 CoNG. REC., at 6728; Wallace \& Fischer, supra note 249, at 2131-32. This policy justification reflected the decision of the Massachusetts Tax Commission. See supra Part VI(D).

252. "From Social forces in war time," Senate, 65 CONG. REC., at 6729.

253. Id.; see Wallace \& Fischer, supra note 249 , at $2131-32$. The example given is that if taxpayer was going to donate $X$ to charity, then the taxpayer, in order to pay the tax on $X$, donates $X$ minus the anticipated tax due on $X$. Consequently, the lack of deduction creates a withholding tax for tax exempt institutions.

254. "From Social forces in war time," Senate, 65 6729; see Wallace \& Fischer, supra 
In 1918, Congress enacted an estate tax charitable deduction, and in 1924, the gift tax charitable deduction. ${ }^{255}$ However, in 1924, the Senate Finance Committee discussed, but rejected, removing the fifteen percent ceiling for taxpayers that in a ten-year period gave more than ninety percent of their income to charity. ${ }^{256}$

In 1936, Congress enacted the corporate charitable deduction, establishing the maximum deduction of five percent of corporate net income. ${ }^{257}$ The 1938 Ways and Means Committee Report, explaining the justification for the corporate deduction, employed the government benefit justification, stating:

The exemption from taxation of money or property devoted to charitable and other purposes is based upon the theory that the Government is compensated for the loss of revenue by its relief from financial burden which would otherwise have to be met by appropriations from public funds, and by the benefits resulting from the promotion of the general welfare. ${ }^{258}$

The populist criticisms expressed in the 1916 Walsh Committee Report neither produced the suggested restrictive regulation nor reduced the growth of private foundations. Against the backdrop of the Great Depression, private foundations still doubled in the thirties. ${ }^{259}$ Of the two significant foundation regulations legislated in the thirties, one resulted from a moralist attack and one from an attack led by tax paying business. In 1934, Congress enacted an anti-lobbying restriction on tax-exempt charities in response to the lobbying activities of Planned Parenthood's predecessor the American Birth Control

note 249 , at $2131-32$.

255. Williams \& Moorehead, supra note 249, at 2100.

256. Vada Waters Lindsey, The Charitable Contribution Deduction: A Historical Review and a Look to the Future, 81 NEB. L. REV. 1056, 1061 (2003).

257. Douglas A. Kahn \& Jeffrey H. Kahn, Gifts, Gafts, And Gefts" - The Income Tax Definition and Treatment of Private and Charitable "Gifts" and a Principled Policy Justification for the Exclusion of Gifts From Income, 78 NOTRE DAME L. REV. 441, 446 (2003); Crimm, supra note 32, at 1107.

258. H.R. REP. NO. 1860, 75th Cong., 3d Sess., at 19 (1938). The section quoted specifically dealt with the reason why charitable deductions were limited to contributions to domestic non-profits rather than including foreign ones. By 1938, Dr. Eliot's government benefit justification overtook his public policy, promoting selfless behavior, justification as the stated reason for the charitable deduction.

259. See Crimm, supra note 32, at 1107 (explaining that the number of foundations more than doubled during the 1930 s and suggesting that the introduction of the corporate charitable exemption was a cause of the growth). 


\section{HOUSTON BUSINESS AND TAX LAW JOURNAL [Vol. IV}

League. $^{260}$ In 1939, in response to complaints of unfair competition by tax paying businesses, Congress enacted the predecessor to the unrelated business income tax, the Supplement U net income tax, to be imposed on a charitable organization's unrelated business net income. ${ }^{261}$

\section{A. 1940-1950: Congress Considers Eliminating the Charitable Exemption, Distinguishes the Private Foundation, Increases Yet Eliminates the Charitable Deduction}

Since 1935, Congress steadily increased the public's tax burden through steeply progressive tax rates. ${ }^{262}$ The combination of the progressive nature of the personal, corporate and estate tax regimes pushed the upper income strata to use foundations. ${ }^{263}$ Meanwhile, the increasing tax burden with its corresponding withholding collection at source created general public sensitivity to taxation as most Americans became first-time taxpayers. ${ }^{264}$ This tax sensitivity naturally led to public interest in the distribution of the tax burden. The foundation's exempt status resulted in the contention of inequitable privilege. ${ }^{265}$

Because of the public perception of a congressionally mandated privilege for the wealthy, in 1943 Congress considered eliminating the foundation's tax exemption, but instead opted for

260. Id. at 1106 (noting that Congress imposed the restriction to thwart the holding in favor of the American Birth Control League in Slee v. Commissioner, 42 F.2d 184 (2d Cir. 1930)). Twenty years later, Senator Lyndon Johnson strengthened the anti-lobbying restrictions because a foundation had supported his opponent in his Senatorial election. See id. at 1112-13. Johnson's amendment attached to the $195430 \%$ charitable deduction increase authorized treasury to remove tax exempt status from a foundation that either sought to influence legislation or to support a political candidate. See 100 CONG. REC. 9604 (1954)

261. Crimm, supra note 32, at 1107 n.77; see also supra Part VIII (noting that this provision merely returned to the historical status quo of the pre-1894 Act in that originally, many states only granted limited tax exemption that did not encompass activities outside those directly related to the charitable purpose).

262. See Peter Dobkin Hall, Philanthropy, the Welfare State, and the Transformation of American Public and Private Institutions, 1945-2000 at 12 (The Hauser Ctr. for Nonprofit Org., Harv. Univ.., Working Paper No. 5, 2000), available at http://www.ksg.harvard.edu/hauser/active_backup/PDF_XLS/workingpaper_5.pdf.

263. See id. at 12-13.

264. See Aprill, supra note 246, at 850 (stating that between 1939 and 1945, taxpayers expanded from approximately $5 \%$ of the population to $74 \%$ ).

265. See Hall, supra note 262, at 12-13; see also supra parts V, VII(B) and (C), and VIII (noting that the argument of inequitable burden merely continued from its mid-1800 origin). In that mid-century, the states' adoption of universal property taxes keenly focused taxpayers' interest on exempt institutions, and the scope of income exempted. The universal income tax produced the same result in the mid-1900s. 
gathering information to investigate the issue. ${ }^{266}$ According to the wording of the Ways and Means Committee report, the Committee contemplated proposing the tax exemption's removal yet: “... [i]n the absence of such information it was felt best to continue the present tax exemption, ... " (emphasis added) ${ }^{267}$ The Committee stated that the disclosed information would be used for the study of foundation's potential tax avoidance behavior:

... [m]any of these exempt corporations and organizations are directly competing with companies required to pay income taxes, and that this practice is becoming more wide spread and affording a loophole for tax evasion and avoidance.

These organizations were originally given this tax exemption on the theory that they were operated not for profit, and that none of the proceeds inured to the benefit of shareholders. However, many of these organizations are now engaged in operation of apartment houses, office buildings, and other businesses which directly compete with individuals and corporations required to pay taxes on income derived from like operations. ${ }^{268}$

Thus, beginning with the Revenue Act of 1943, Congress required certain non-publicly supported foundations to file annual returns disclosing gross income, receipts, and disbursements. ${ }^{269}$ In establishing this reporting requirement, Congress discriminatorily distinguished between traditionally exempt institutions, publicly supported foundations and all other foundations. The legislation's new reporting requirements did not apply to religious organizations, schools, certain fraternal groups, publicly supported charitable organizations, and certain government corporations. ${ }^{270}$ This policy of applying greater regulation to untraditional and non-publicly supported foundations, i.e., private foundations became the cornerstone of

266. H.R. REP. NO. 78-871, at 25 (1943).

267. H.R. REP. NO. 78-871, at 25 (1943).

268. H.R. REP. No. 78-871, at 25 (1943).

269. See Crimm, supra note 32, at 1109 n.93 (citing H.R. REP. No. 78-871, at 24-25 (1943)); see also Williams \& Moorehead, supra note 241, at 2101.

270. See Crimm, supra note 32, at 1105 n.65; see infra part XV. In 1969, Congress codified the definition of private foundations to be all foundations other than a more expanded list than the 1943 legislation. 


\section{HOUSTON BUSINESS AND TAX LAW JOURNAL [Vol. IV}

private foundation legislation and the backdrop of the further investigations leading thereto.

Congress, having just contemplated removing the exemption, a year later in the 1944 Individual Income Tax Act raised the fifteen percent deduction ceiling by expanding the base upon which it was applied, from taxable net income to adjusted gross income, as it remains applied today. ${ }^{271}$ However, in simplifying the computation of income tax for a majority of taxpayers through the standard deduction, the 1944 Individual Income Tax Act limited the charitable deduction to only taxpayers that itemized. ${ }^{272}$ Representative Carl Curtis, a proponent to save the charitable deduction for non-itemizers, argued:

It has been the basic policy in America that our tax program is one that considers a gift to the U.S.O., the Red Cross, a children's home, a hospital, a home for the aged, a college, a mission, a church, or any other institution rendering service and mercy, an expenditure for the public good, and, therefore exempt from taxation. ${ }^{273}$

He also noted that non-itemization created a disincentive to giving by taxing contributions that would in affect "cripple all of these worth-while [sic] institutions so that they must come to the Federal Government for a subsidy."274

In response to Congressman Curtis' allegation that the lack of deduction for low income taxpayers created a disincentive for charitable giving, Congressman Robert Doughton, Ways and Means Committee Chair, retorted that taxpayers gave contributions for the "worthy causes such contributions advance" as opposed to reducing their taxes. ${ }^{275}$ Senator Walter George, Finance Committee Chair, argued:

The committee does not believe that it can be proved that a tax incentive has been an important

\footnotetext{
271. See Lindsey, supra note 256 , at 1062.

272. Aprill, supra note 246 , at 850 .

273. Id. at 851 (citing 90 CONG. REC. 3972-73, 4029 (1944) (statement of Rep. Curtis)).

274. Id. at 850-51 (quoting 90 CoNG. REC. 4029 (1944) (statement of Rep. Curtis)); see supra Part VII(C) wherein Dr. Eliot argued similarly.

275. Id. at 851 (quoting Ways and Means Committee, 90 CoNG. REC. 3975 (1944) (statement of Chairman Doughton)).
} 
factor in the making of such gifts by individuals having less than $\$ 5,000$ of adjusted gross income, and certainly the $\$ 500$ standard deduction will not remove the tax incentive for persons in the higher brackets, upon whom the charities depend for contributions in substantial amounts. ${ }^{276}$

Supporters of the simplification, which Congress enacted, defended that the standard deduction took into account a modest average charitable deduction of $2 \frac{1}{2} \%$. $^{277}$

In the much publicized Ford Foundation gift by Henry Ford in 1947, the Ford family maintained the voting stock, and thus control, of Ford Motor Company while bequeathing the nonvoting, dividend bearing stock to the foundation. ${ }^{278}$ As a result of the publicity, in 1950 President Harry Truman complained in his address to Congress that charitable trust funds were but vehicles for the donors' speculative investments that misused "funds intended for charitable purposes." Treasury Secretary John Snyder presented the following testimony to the Ways and Means Committee, explaining:

Another... abuse of tax exemption involves the establishment of so-called charitable foundations or trusts which serve as a cloak for controlling businesses. The present law permits the transfer of business investments to tax-exempt trusts and foundations for these purposes without payment of estate or gift taxes. The income subsequently received from the business is exempt from income tax.

The abuse to which this type of device lends itself is the retention and reinvestment of a major share of the trust income in a manner which will benefit the grantor. ${ }^{280}$

276. Id. at 851-52 (quoting Finance Committee, 90 CONG. REC. 4704 (1944) (statement of Chairman George)).

277. Id. at 852 (citing 90 CONG. REC. 3973 (1944) (statement of Rep. Robertson)).

278. See Brody, supra note 11, at 923-24; Crimm, supra note 32, at 1109 n.91 (noting that while Henry Ford established the Ford Foundation in 1936, he had been an outspoken critic against philanthropy, ignoring the foundation until his 1947 bequest); see Henry Ford's testimony at the Walsh Commission Vol. VIII, pp 7630.

279. Thomas A. Troyer, The 1969 Private Foundation Law: Historical Perspective on its Origins and Underpinnings, 27 The EXempt Organization TAX Rev. 52, 53 (2000); Marsh, supra note 10, at 148.

280. Troyer, supra note 279, at 53 (quoting from Revenue Revisions of 1950: 
President Truman also raised the issue of business acquisitions by tax-exempt organizations, most famously New York University's acquisition of the Mueller Macaroni Co, which removed these acquired businesses from the corporate tax base. ${ }^{281} \mathrm{He}$ stated that tax-exempt organizations were "misused in a few instances to gain competitive advantage over private enterprise through the conduct of business and industrial operations entirely unrelated to educational activities." ${ }^{282}$ Treasury Secretary Snyder presented several examples of noncharitable related businesses acquired by tax exempts, including the production of automobile parts, china-ware, food products and the operation of theaters, oil wells and cotton gins. ${ }^{283}$ The President, Congress, and public, from the data gleamed from the several years of annual information returns and the subsequent press reports, felt confirmed in their suspicion that the industrialist class and their families rampantly abused foundations to maintain control of family businesses while avoiding taxation. ${ }^{284}$

\section{B. The Tempered 1950 Act Curbs Abuse}

In order to curb the perceived abuse, in 1950 the House passed a stringent bill that (1) denied the charitable deduction for a family's contribution of its controlled business to its foundation; (2) levied tax upon undistributed investment income; (3) forbid contributors, officers, directors, trustees, and certain related parties from engaging in financial transactions with their foundation; and (4) levied tax on "income derived from a trade or business 'regularly carried on' by a tax-exempt organization if the business is not 'substantially related' to the performance of the functions upon which the organization's exemption is based."285

The Senate outright rejected the House's proposed denial of deduction for contributed but controlled family businesses. ${ }^{286}$ The

Hearings on H.R. 8920 Before the House Committee on Ways and Means, February 3 , 1950, 81st Cong., 2d Sess. 19 (1950) (Statement by Hon. John W. Snyder, Secretary of the Treasury)).

281. See Evelyn Brody, Of Sovereignty and Subsidy: Conceptualizing the Charity Tax Exemption, 23 J. CORP. L 585, 608 (1998).

282. Mass. Med. Soc'y v. United States, 514 F.2d 153, 154 (1st Cir. 1975) (citing Hearings on Revenue Revision Before the House Comm. on Ways and Means, 81st Cong., $2 d$ Sess. 4, $5(1950)$ ).

283. Id.

284. See Crimm, supra note 32, at 1109; Marsh, supra note 10, at 148.

285. Troyer, supra note 279, at 53; Williams \& Moorehead, supra note 241, at 2101 (quoting from S. REP. No. 2375, 81st Cong., 2nd Sess. 3081 (1950)).

286. S. REP. NO. 2375, at 3092 (1950). 
Senate justified the situation of continued control with two propositions. First, the Senate reasoned that income of contributed business interests must be used for charitable purposes. ${ }^{287}$ Second, the Senate weighed that the loss of contributed funds to private charity would be greater than the House proposal's increase in tax revenue. ${ }^{288}$

Regarding a foundation's accumulated income, the Senate rejected the House's proposed levying of tax as too inflexible and likely to damage worthwhile charities. ${ }^{289}$ The Finance Committee replied:

Your committee does not question the contention that some organizations are abusing their taxexempt privilege by undesirable accumulations of income. However, witnesses before, and statements presented to, your committee brought out quite clearly that the measure passed by the House was too inflexible and as a result would seriously injure many worth-while educational and charitable projects. To mention some problems under the House provision:

(1) A foundation could not use any of its income to endow another organization unless the latter was of a type not subject to the accumulations tax.

(2) A foundation could not set aside funds which, if subsequently matched by another organization, would be spent for some specific purpose.

(3) Foundations may find that as the result of a crisis, such as a war, they are unable to spend their funds for a period of time for the purposes for which they were organized.

(4) Funds irrevocably set aside in a 5-year trust fund as provided by the House bill may not be needed at the end of the 5-year period for the specific project for which they were set aside, and 
(5) One year's earnings, the accumulations permitted by the House bill, may not be sufficient to even out variations in the earnings or needs for funds of a foundation.

The Senate instead voted in favor of expanding the information disclosure beyond the requirements of the 1943 Act. ${ }^{290}$ The Senate projected that the requirement to publish information about the accumulations would encourage distributions while revealing the extent of the accumulations. ${ }^{291}$ The expanded information return included: (1) its gross income for the year; (2) its expenses attributable to such income; (3) its disbursements out of current income for its educational, charitable, etc., purpose; (4) its accumulation of income within the year; (5) its prior accumulations of income; (6) its disbursements out of principal; and (7) a balance sheet. ${ }^{292}$

As to the House's call for the elimination of all financial transactions between a foundation and the donors and related parties, the Senate stated that such transactions should be allowed but limited in extent to an arm's length standard. ${ }^{293}$ The House reported that donors "either have derived, or at least have had the opportunity to derive, substantial benefits from their dealings with the trusts or foundations." ${ }^{294}$ According to the House, the benefits:

290. Troyer, supra note 279, at 53-54 (referring to Revenue Act of 1950, Pub. L. No. 81-814, S. REP. No. 2375, 81st Cong., 2nd Sess. 1950).

291. S. REP. No. 2375 , at 3087 (1950).

292. Id. at 3088 .

293. Troyer, supra note 279, at 53-54; see S. REP. No. 2375, at 3090 (1950):

It is important to note in the above listing of prohibited transactions that under your committee's bill the prohibited transactions are restricted to transactions in which a donor (including a testator) or a member of his family is likely to gain some special benefit from the transaction. Moreover, these prohibited transactions do not apply to transactions between the exempt organization and its trustees, directors or officers.

294. S. REP. NO. 2375, at 3089 (1950)S. REP. NO. 2375, 81st Cong., 2nd Sess. 3089(1950). The House's tack of prohibiting such transactions aligned with Dr. Eliot's and the Massachusetts Tax Commission's two contentions for exemption: (1) that the exempt property neither be owned like ordinary property nor be remunerative, and (2) that charitable gifts be an expression of benevolence not driven by private gain. Further, the Massachusetts Tax Commission's concluded that exempt property should not be controlled by private parties for private ends. See supra Parts VII(C) \& (D). The 1909 Tariff Act's personal inurement clause codified these contentions. The Senate's solution abrogated these contentions in that it allowed the donor to obtain an arm's length remuneration or gain in dealing with the foundation's assets. The Senate's allowance of an arm's length gain expanded the historically intended scope for a donor's interaction with charitable gifts. 
take the form of selling securities to, or purchasing securities from, the trust or foundation under conditions which benefit the donor ... from the borrowing of funds from the exempt organizations with the payment of abnormally low interest rates by the donor or the assumption of abnormal risk by the exempt organizations ... payment of excessive salaries to the donor or a member of his family as an official of the trust or foundation, or of rendering services on a preferential basis to the donor or a firm with which he is associated. ${ }^{295}$

In its analysis, the Finance Committee replied:

Your committee is in sympathy with the goals sought by the above provisions of the House bill but believes they would be unduly harsh in their application. No objection is seen to engaging in transactions with donors if these transactions are carried out at arm's length. Moreover, many foundations and trusts would find it either impossible or very difficult to stipulate in their instruments that they will not engage in the specified transactions even though they never have done so and never expect to do so. Nevertheless, donors to such organizations could not deduct their contributions under the income, estate, or gift taxes. Also an organization might unintentionally violate one of the requirements, such as paying what might be held to be an unreasonable salary, and then, when its return was examined several years later, find that it would lose its exemption for the past several years.

As a result your committee has recast the House provisions to remove their harshness. Prohibited transactions have been redefined as including only transactions in which an organization-

(1) lends any part of its income or corpus without adequate security or at an unreasonable rate of interest to donors, members of their families, or a corporation which they control, 
(2) pays any compensation to such persons other than a reasonable allowance for personal services actually rendered,

(3) makes any part of its services available to such persons on preferential basis,

(4) makes any substantial purchase of securities or other property from such persons without adequate consideration,

(5) sells any substantial part of its securities or other property to such persons without adequate consideration, or

(6) engages in any other transaction which results in a substantial diversion of its income or corpus to such persons. ${ }^{296}$

Regarding the application of the expanded reporting requirements and the "arm's length" rule, Congress distinguished "public" type foundations from the general class of foundations, continuing the distinction inaugurated in the 1943 Revenue Act's reporting requirements. ${ }^{297}$ These new regulations did not apply to "religious organizations, schools, publiclysupported organizations, governmentally supported organizations, and medical organizations, including hospitals."298 The Senate Finance Committee explained that because these organizations are "public," they "are not believed likely to become involved in any of the prohibited transactions."299 Thus, the 1950 Revenue Act reiterated the distinction, based on the criterion of either public nature or public support, between public and all other (private) foundations that continues to set the tone of private foundation regulation..$^{300}$

Regarding the House's proposal in response to President

296. S. REP. NO. 2375 , at 3080 .

297. Crimm, supra note 32 , at 1109 n.96; Williams \& Moorehead, supra note 241, at $2102 \mathrm{n} .22$ (The organizations required to file this information, which is to be made available to the public, include all organizations exempt under $\S 101(6)$ now required to file informational returns (Form 990) under $§ 54(\mathrm{f})$ ).

298. Crimm, supra note 32 , at 1109 n.96. S. REP. No. 2375, at 3091; Marsh, supra note 10 , at 149 .

299. Crimm, supra note 32, at 1109 n.96; see S. REP. No. 2375, at 3091.

300. See Marsh, supra note 10, at 149; Troyer, supra note 279, at 54. 
Truman's address for the taxation of business income of charities not related to the charitable mission, the Finance Committee concurred that unfair competition with tax paying business justified the levying of tax to create a level playing field. ${ }^{301}$ Commenting on President Truman's publicized example of NYU's acquisition of C.F. Mueller, a macaroni production company, Congressman Dingle argued that "[e]ventually all the noodles produced in this country will be produced by corporations held or created by universities... and there will be no revenue to the Federal Treasury from this industry." ${ }^{302}$ The Finance Committee concluded:

The problem at which the tax on unrelated business income is directed is primarily that of unfair competition. The tax-free status of section 101 organizations enables them to use their profits tax-free to expand operations, while their competitors can expand only with the profits remaining after taxes....

In neither the House bill nor your committee's bill does this provision deny the exemption where the organizations are carrying on unrelated active business enterprises, nor require that they dispose of such businesses. Both provisions merely impose the same tax on income derived from an unrelated trade or business as is borne by their competitors. In fact it is not intended that the tax imposed on unrelated business income will have any effect on the tax-exempt status of any organization. ${ }^{303}$

301. S. ReP. No. 2375, at 3081; H. REP. No. 2319, $81^{\text {th }}$ Cong., 2d Sess. $36-7$ (1950); Williams \& Moorehead, supra note 241, at 2101.

302. Brody, supra note 281, at 608 (citing Hearings Before the House Comm. on Ways and Means, 81st Cong., 2d Sess. 580 (1950) (remarks of Rep. Dingell)). The Commissioner challenged New York University's (N.Y.U.) contention, based upon its own tax exemption, of exemption for the macaroni production company. C.F. Mueller Co. v. Comm'r, 190 F.2d 120, 121 (3d Cir. 1951). The macaroni company's profits exclusively benefited the law school. Id. The Court found for N.Y.U. based on the historical interpretation of the exemption. Id. at 123 . According to the court:

We agree that the statute lends itself to the result so far achieved... since it plainly contemplates that there may exist income otherwise taxable and does not proscribe any particular source of income... The policy ... is that the benefit from revenue is outweighed by the benefit to the general public welfare gained through the encouragement of charity.... This point of view has predominated through the more than thirty years. ...

Id. at $121-22$

303. S. REP. NO. 2375, at 3081. 
The Senate bill listed several examples of what constituted substantially related business income as well as exceptions to the new rule's application. ${ }^{304}$ By example, universities' substantially related income included athletic programs and university presses. ${ }^{305}$ The Senate provided exception for the sale of gift merchandise, such as old clothes, which were donated to be sold with the proceeds going to the exempt organization. ${ }^{306}$

The Conference Committee's compromise primarily favored the Senate's less restrictive policy for private foundations, and was legislated into the Revenue Act of $1950 .^{307}$ Thus, the Revenue Act of 1950's new regulations included: (1) the requirement of arm's length dealing for private foundations when engaging in "prohibited transactions" with, or for the benefit of, donors and related parties (known as "self-dealing"), the corresponding sanction for engaging in a non-arm's length "prohibited transactions" of self-dealing was to be stripped of section 501(c)(3) tax exempt status; ${ }^{308}$ (2) levying tax upon a foundation's unreasonable accumulation of income; ${ }^{309}$ (3) levying tax on a foundation's unrelated business income (known as "UBI"); ${ }^{310}$ and finally (4) expanding disclosure requirements. ${ }^{311}$

\section{The 1952 Cox Committee}

The 1950 Revenue Act reforms did not satisfy Congress' anti-industrialist wing but rather strengthened the fervor of attacks on the foundation sector. ${ }^{312}$ Interestingly, the thrust of the attacks changed from accusing the foundations of

304. See id. at 3082 .

305. See id.

306. See id.

307. See PUB. L. No. 81-814, 64 Stat. 947 (1950) (enacting I.R.C. $\$ \$ 502,503,504$, and 511-4, reenacted as part of the I.R.C. of 1954); Troyer, supra note 279, at 54 .

308. See Marsh, supra note 10, at 148-49.

309. See Troyer, supra note 279 , at 53-54 (noting that the loss of exemption for accumulated income applied when it was "(1) unreasonable in amount or duration, (2) used to a substantial degree for other than exempt purposes, or (3) invested in such a manner as to jeopardize the carrying out of exempt functions."). Considering the focus on the issue of charitable institutions accumulations from James Madison to the 1916 Walsh Commission, this regulation was a long time coming. Dr. Eliot relinquished the point that exempt institutions property in excess of the requirements to accomplish its charitable purpose should be taxed. However, the I.R.S. did not actively pursue enforcement of this regulation because of the severity of the penalty. In the 1965 Treasury Report (see infra Part XIII), Treasury noted that its study found that a very small percentage of private foundations unreasonably accumulated income.

310. See Revenue Act of 1950.

311. Id.

312. See Crimm, supra note 3, at 788. 
manipulating social and public policy in favor of industrialism to accusing them of promoting leftwing causes. ${ }^{313}$ In typical McCarthy-esque rhetoric, Congressman Edward Cox charged foundations with funding "outright communists, fellow travelers, socialists, do-gooders, one-worlders, wild-eyed Utopians and wellmeaning dupes." ${ }^{314}$ Yet these attacks fell on deaf ears because Congress enacted two increases in the deduction ceiling, resulting in a maximum thirty percent of adjusted gross income. ${ }^{315}$

In 1952, Congress established the "Select Committee to Investigate and Study Educational and Philanthropic Foundations and Comparable Organizations which are Exempt from Federal Income Taxation" (known as the "Cox Committee") "to determine which such foundations and organizations are using their resources for un-American and subversive activities or for purposes not in the interest or tradition of the United States." ${ }^{\text {"16 }}$ Three distinct instigators directed the Commission's mission. ${ }^{317}$ First, the nationalists, known as the Brickerites, alleged that the Foundation's support of international organizations, such as the United Nations, threatened U.S. sovereignty. ${ }^{318}$ Second, the progressives desired to use the Committee to attack the potential presidential candidacy of General Dwight Eisenhower, who was supported by some directors of prominent foundations, against their candidate Senator Robert Taft. ${ }^{319}$ Third, the bi-partisan anti-communist group viewed foundations with the same disdain as the previous anti-industrialists. ${ }^{320}$

The Cox Committee sent questionnaires to over fifteen hundred organizations, interviewed over two hundred persons, heard the testimony of twenty individuals, received prepared statements from an additional seventy, and communicated with a

313. See Foundations, PRIVAte GIVING, AND PUblic Policy: Report AND RECOMMENDATIONS OF THE COMMISSION ON FOUNDATIONS AND PRIVATE PHILANTHROPY 65 (1970) [hereinafter PETERSEN COMMISSION].

314. Petersen Commission, supra note 313, at 65 (quoting Congressman Cox of Georgia in the American Legion Magazine article entitled "Let's Look at Our Foundations").

315. See Lindsey, supra note 256, at 1062-63.

316. Brody, supra note 11, at 924 (citing PETER DOBKIN HALL, INventing The NONPROFIT SECTOR 182, at 67-68, 291 n.191 (1992) that quotes from H.R. Res. 561, in Hearings Before the Select Comm. to Investigate Tax-Exempt Foundations and Comparable Organizations, $82 \mathrm{~d}$ Cong., 2d Sess. 1 (1952)).

317. See PETERsen CoMmission, supra note 313, at 65-66.

318. See id. at 65.

319. See id.

320. See id. at 65-66. 
further two hundred by telephone and post. ${ }^{321}$ The Cox Committee estimated the existence of approximately thirty thousand tax exempt organizations of which only between sixty and one hundred qualified as private foundations with assets of ten million dollars. ${ }^{322}$ Also, the Cox Committee estimated that private foundations constituted but three percent of charitable spending. ${ }^{323}$

Contrary to the desire of the Cox Committee's instigators, its 1953 Final Report concluded that Congress should foster the taxexempt sector with expanded tax incentives, but require public accounting. ${ }^{324}$ The Cox Committee proposed that foundations justified the incentives because they provided the necessary venture capital "expended in advancing the frontiers of knowledge." ${ }^{325}$ The Committee explained that the large foundations played a more significant venture capital role than government could play, stating:

With trained professional staffs drawing upon knowledge gained through decades of experience, with the ability to attract and hold men of great competence both in their governing boards and staffs, with large sums of money to back their judgments and with complete freedom to spend the money on calculated risks, they are able to do that which neither government nor individuals, nor even small foundations, could or probably should attempt. $^{326}$

The Committee pointed out that foundations not only significantly impacted the fields of health, medicine, natural science, social science, public administration, international relations, the arts, economics, amongst other areas, but were the best suited vehicle for continued research in these areas. ${ }^{327}$ The

321. House of Representatives Final Report of THE Select Committee to Investigate Foundations and OTher ORganizations, H. ReP. No. 2514, 82nd Cong., 2nd SESS., at 2 (1953) [hereinafter COX COMMITTEE].

322. Cox CommitTeE, supra note 321 , at 2. Private foundations, under the Committee definition, excluded colleges, universities, and religious organizations. Id.

323. Id. at 3 .

324. Id. at 13 .

325. Id. at 3; Williams \& Moorehead, supra note 241, at 2104. Senator Cox died before the issuance of the committee's final report.

326. Cox CommitTEE, supra note 321, at 4. This point evolved from Dr. Eliot's contention that charities presented a better fora for determining and providing public service. See supra Part VII(C).

327. See Cox CommitTEE, supra note 321 , at 4. 
Cox Committee concluded that, probably in reference to the 1916 Walsh Commission, "[t]he foundation, once considered a boon to society, now seems to be a vital and essential factor in our progress." 228

The Cox Committee stated mild criticisms of foundations' activities compared to the intent of the Committee's instigators. First, the Cox Committee found few instances of employment of relatives by the smaller foundations. ${ }^{329}$ Second, the Cox Committee reviewed 35,731 grants, of which it found only 63 to be questionable. ${ }^{330}$ It found that the Soviet Union and its U.S. Communist party ally had a specific program to infiltrate foundations in order to manipulate their work, but that rare circumstances of that infiltration occurred, with the notable case being Alger Hiss. ${ }^{331}$ Third, the Cox Committee found that the public mistrusted foundations because of the lack of geographical representation amongst the directors who primarily all resided in New York. ${ }^{332}$ The Report suggested that foundations, to deal with these criticisms, provide significantly more information in the annual information return, including: (1) total annual contributions; (2) gross annual income; (3) expenses attributable to such income; (4) breakdowns of administrative expenses, including salaries above four thousand dollars; (5) the amount, general purpose, and recipients of grants; (6) accumulation of income during the year and aggregated throughout its life time; (7) balance sheet; and (8) contributors over two hundred dollars and amounts contributed. ${ }^{333}$

\section{The 1954 Reece Committee - If at First You Don't Succeed, Try, Try Again}

Not receiving the conclusions that it sought, in 1954 the populists initiated a new special committee (the "Reece Committee") to re-investigate tax-exempt private foundations. ${ }^{334}$ Congressman B. Carroll Reece's (Tennessee) on the House floor responded to the Cox Committee's report in favor of a reinvestigation:

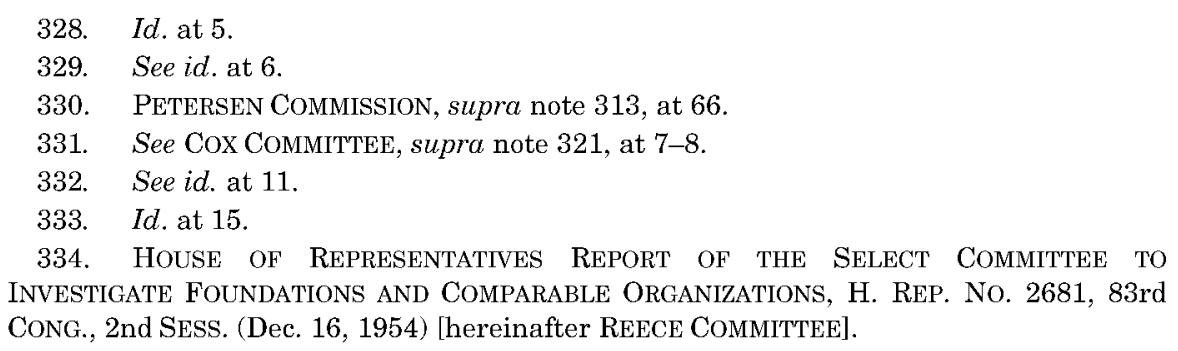

334. House OF Representatives Report OF the Select Committee TO INVESTIGATE FOUNDATIONS AND COMPARABLE ORGANIZATIONS, H. REP. No. 2681, 83rd CONG., 2nd SESS. (Dec. 16, 1954) [hereinafter REECE COMMITTEE]. 


\begin{abstract}
Some of these institutions support efforts to overthrow our government and to undermine our American way of life.... Here lies the story of how communism and socialism are financed in the United States .... There is evidence to show that there is a diabolical conspiracy back of all this . . . Organizations which are primarily committed to a given ideology have received large grants from big foundations over many years. ${ }^{335}$
\end{abstract}

The five-person Committee, split between three foundation opponents and two foundation supporters, held contentious hearings. ${ }^{336}$ The minority report attacked that "[i]t not only disagree[d] with [the majority] report but earnestly believe[d] that it should never have been published,"337 stating that the 1953 Cox Report represented a fair public trial of private foundations but that the Reece Committee's majority report represented pre-fabricated judgments without the right for the foundations to testify in defense. ${ }^{338}$

The majority report first defended that it favored of the role of foundations in American society:

The Committee was and is well aware of the many magnificent services which foundations have rendered to the people of the United States in many fields and many areas, particularly in medicine, public health and science. Nothing has occurred to change its initial conviction that the foundation, as an institution, is desirable and should be encouraged. ${ }^{339}$

Thereafter, the tone turned negative: "But foundations play

335. Petersen Commission, supra note 313, at 66. Congressman Reece sat on the Cox Committee but only attended one of eighteen sessions. He warned the Cox Committee in an attached paragraph to its final report that, because of the lack of investigative time, he would seek a re-investigation. Id. at 66-67.

336. See REece Commitee, supra note 334, at 223-24. The Reece Committee consisted of three Republican critics and two Democratic supporters. Chairman Reece commented, referring to the ranking minority, Democrat, member, "Mr. Hays has assumed an attitude of aggressive suspicion and insulting distrust of the majority .... He has said frequently that he has known in advance what the majority was going to decide."

337. Id. at 421 .

338. See id. at $422-23$.

339. Id. at 3 . 
a part in our society the importance of which can hardly be exaggerated; and, in the course of our investigation, evidence of very grave abuses accumulated to the point of indicating that intervention by Congress to protect our society is badly needed." $\$$ i40

The Reece Committee opened with the rationale for the congressional inquiry; that the tax exemption is a form of government subsidy that increases the burden on all non-exempt taxpayers. ${ }^{341} \quad$ Foundations are established, concluded the Committee, to avoid the "confiscatory" rate of estate tax and to maintain control of family businesses. ${ }^{342}$ Once the family, such as Ford, tucked its business inside the tax exempt foundation, the company could be run predatorily without the need for profits, thus dividends, against its competitors. ${ }^{343}$ The Committee contended that while Ford had not pursued such a policy, the foundation, in carrying the name of the company, advertised with public money to the disadvantage of its competitors. ${ }^{344}$

Regarding corporate established foundations and the corresponding donations, the Reece Committee presented both charitable supporters and critics. ${ }^{345}$ Labor and shareholders criticized corporate donations as denying increased wages and dividends respectively. ${ }^{346}$ Supporters responded: (1) that corporations have a civic charitable duty; (2) that corporate giving surpassed that of individuals, making it more valuable to charities; (3) that, because individuals only receive dividends reduced by corporate tax, corporate charity is cheaper than giving by individuals; (4) that corporate charity can be used to benefit its community, thus employees; and (5) corporate

340. Id. "The theory behind such restrictions," according to the majority, "[was] simply that, as exemptions are acts of grace, the government may clearly impose such conditions on the exemptions as may be calculated to prevent abuse of the privilege and to prevent the use of the exempted funds against the public interest." Id. at 4; see also supra Part V (noting that the argument of inequitable burden carried forward from the 1850s).

341. Id. at 4 .

342. See REECE COMMITTEE, supra note 334, at 6. Examples given included the Ford Foundation, the Duke Foundation, consisting of assets of Duke Power companies, the Reid Foundation, associated with the New York Herald-Tribune, and Meyer Foundation, owning the Washington Post and Times-Herald. The 1916 Walsh Commission also cited the reasons of tax avoidance and retaining control of family business for the establishment of foundations. In terms of establishing foundations, Congress specifically legislated, but limited, the income tax avoidance through the annual charitable deduction ceiling.

343. See id. at 7.

344. See id.

345. See id. at 12 .

346. See id.; see also WALSH COMMISSION, supra note 205, at 7434 (where Mr. Untermyer made a similar argument). 
donations create benefits to the company, the industry, and future employees, through earmarked grants to educational and scientific institutions. ${ }^{347}$ The Committee proffered that a corporation cannot act charitably because it lacks the charitable criteria of human conscience. ${ }^{348}$

The Reece Committee's primary concern with foundations centered on their left-leaning social engineering coupled with their financial control over universities and board crossmembership control over media and significant corporations. ${ }^{349}$ Committee testimony and research followed closely the lines of the 1916 Walsh Report, uncovering examples of foundation influence over university education and media coverage. The Committee pointed the finger at unregulated foundation bureaucrats who "exert an influence on academic life second to no other group" through choosing the recipients of the enormous grant funds and through controlling the media coverage of themselves. ${ }^{350}$ The Committee concluded that:

The inherent uncertainties of research in the social sciences, the enormous factor of indefiniteness, the impossibility of truly experimenting to test a conditional hypothesis before proclaiming it as a proven conclusion, the grave danger of fallacious results, makes it highly questionable whether public money should be so used to promote abandonment of institutions and ways of life which have been found satisfactory, in favor of questionable substitutes. ${ }^{351}$

The Reece Committee's majority submitted the expected populist conclusions, stating that foundations were tax avoidance vehicles that fostered the control of the wealth, control of public policy and the media, and encouraged "empiricism," "moral relativity," and "collectivist" political opinions. ${ }^{352}$ The Reece Committee recommended a definition, and a distinct set of tax based regulations, for private foundations in contrast to section

347. REECE COMMITTEE, supra note 334, at 12.

348. See id. at 12-13.

349. See generally id. at 30-59.

350. Id. at 37 .

351. See id. at 31 . In reaching its conclusions regarding the role of foundations in the area of social sciences, the Committee defined the scope of the term "social sciences" as including the fields of economics, sociology, government, demography, statistics, history, and political science. See id. at 30.

352. See Crimm, supra note 32, at 1112; see also Brody, supra note 11, at 924. 
501(c)(3) foundations. ${ }^{353}$ The Reece Committee's recommended: (1) limiting a foundation's life span from ten to twenty-five years; (2) a director representing state government; (3) mandatory distribution of income within two to three years; (4) restriction on corporate control; (5) university grants given free of conditions and limitations; (6) prohibition on political activities; and (7) increased tax audits. ${ }^{354}$ Unlike the 1916 Walsh Committee, the Reece Committee rejected a federal incorporation requirement for foundations as an infringement of states' rights. ${ }^{355}$

\section{E. Did the Reports Have Any Affect? Congress Increases the Deduction}

In 1952, during the ongoing Cox Commission's investigation, Congress raised the deduction ceiling from fifteen to twenty percent of adjusted gross income followed by an increase during the ongoing Reece Committee's Report to thirty percent in $1954 .{ }^{356}$ Also, the 1954 Act included the formerly rejected 1924 Senate Finance Committee proposal for the removal of the deduction ceiling for taxpayers who gave more than ninety percent of their income to charity in eight out of ten years. ${ }^{357}$

353. See REECE COMMITTE, supra note 334, at 213. In its 1965 report, Treasury included the same proposal, which Congress enacted in 1969.

354. See id. at 214-22. Each of these recommendations evolved from the concerns raised before or during the Massachusetts' Tax Commission report. Limiting a foundation's life evolved from the concerns of mortmain and the concerns of accumulation raised by Presidents Madison and Grant, with this inevitable recommendation evolving from the Massachusetts' Tax Commission minority's reasoning that what the state giveth, the state can taketh away. The minority report stressed the state's role to ensure that the exempt institution more efficiently employed resources than the state, which would have provided the justification for the state appointed director. Required distribution merely enforced the government-benefit justification for exemption posited by Dr. Eliot, accepted by Congress and the Courts. The following three points restricting control and influence address the concerns brought by Madison that such institutions could affect democratic institutions. The final recommendation of increased tax audits had been proposed by the Massachusetts' Tax Commission minority, that the state conduct annual audits to reevaluate the need and scope of an institution's exemption. See supra Part VII.

355. The Reece Committee stated on numerous occasions that it particularly did not support federal government encroachment into the states' domain over the regulation of corporations. See REECE COMMITTEE, supra note 334, at 215.

356. See Lindsey, supra note 256, at 1062-63.

357. See Internal Revenue Code of 1954, PuB. L. No. 591 Ch. 736; 83d Cong., 2 d Sess.; H.R. 8300; 68A Stat. 1.83:

SEC. 170., Charitable, etc., contributions and gifts

(a) Allowance of deduction. -

(C)Unlimited deduction for certain individuals - The limitation in subparagraph (B) shall not apply in the case of an individual if, in the taxable year and in 8 of the 10 preceding taxable years, the amount of the charitable contributions, plus the amount of income 
The 1952 Senate Finance Committee, justifying the deductible increase, stated:

Your Committee is of the opinion that by increasing the 15 percent limit to 20 percent, much needed relief will be given to colleges, hospitals, and other organizations who are becoming more and more dependent upon private contributors to enable them to balance their budgets and carry on their programs. The plight in which many of our educational systems find themselves at the present time is due to the fact that their endowment income is inadequate to meet rising costs.... Many of the smaller colleges whose alumni have not sufficient means to make adequate contributions are able to continue their existence only through gifts or contributions received by one or two prominent families in their community. Your Committee believes that it is in the best interest of the country to encourage private contributions to these institutions . . . ${ }^{35}$

The 1954 Act broke ground by applying the discrimination in favor of traditional publicly supported foundations over private foundations, established by the Act of 1943, to the maximum allowable charitable deduction. The congressional policy for discriminating against private foundations did not rest on populist sentiment expressed in the Reece Committee, but rather was justified as an offset to the rising operating costs and modest endowment income of the public charities. ${ }^{359}$ The 1954 Act enacted an additional ten percent deduction, thus a total of thirty percent, for contributions made to qualifying charities. ${ }^{360}$

tax (determined without regard to chapter 2, relating to tax on self-employment income) paid during such year in respect of such year or preceding taxable years, exceeds 90 percent of the taxpayer's taxable income for such year, ....

358. Williams \& Moorehead, supra note 241, at 2102 (quoting S. REP. No. 1584, 82 Cong., 2 d Sess. 2 (1952)).

359. Bittker \& Rahdert, supra note 163, at 337; Lindsey, supra note 237, at 1063 (citing H.R. REP. No. 83-1337 (1954), reprinted in 1954 U.S.C.C.A.N. 4017, 4050, which states: "This amendment by your committee is designed to aid these institutions in obtaining the additional funds they need, in view of their rising costs and the relatively low rate of return they are receiving on endowment funds.").

360. See Lindsey, supra note 256, at 1063 . The 1954 version of the Internal Revenue Code stated, in pertinent part:

SEC. 170. Charitable, etc., contributions and gifts 
Qualifying charities for which taxpayer could take advantage of the additional ten percent deduction included churches, educational institutions, and hospitals. ${ }^{361}$ However, Congress did not limit private foundations from taking advantage of the deductible ceiling elimination for taxpayers contributing more than ninety percent of their income in eight out of ten years.

\section{1960-1970: Patman's CRUSAde Against the PRivate FOUNDATION}

The Cox Commission and Reece Committee, like the 1916 Walsh Commission report, did not affect the increase in private foundation, growth in their assets, or legislatively punish private foundations. ${ }^{362}$ The fifties economic expansion resulted in substantially more private foundations, exceeding the thirties and forties foundation growth trend, increasing at the average of 1,200 per year to a total of $13,000 .^{363}$ In 1958,1960 , and 1962 , congressional legislation generally supported foundations, allowing a following year carry over for excess charitable deduction and a monthly fifty dollars deduction for educational maintenance expenses, expanding the list of qualifying charities for the full thirty percent deduction, though limiting to fair market value the deduction for property contribution. ${ }^{364}$ The

(a) Allowance of deduction.

(A) Special rule. - Any charitable contribution to (i) a church or a convention or association of churches, (ii) an educational organization referred to in section 503(b)(2), or (iii) a hospital referred to in section 503(b)(5), shall be allowed to the extent that the aggregate of such contributions does not exceed 10 percent of the taxpayer's adjusted gross income...

(B) General Limitation. - The total deductions under subsection (a) for any taxable year shall not exceed 20 percent of the taxpayer's adjusted gross income computed without regard to any net operating loss carryback to the taxable year under section 172. For purposes of this subparagraph, the deduction under subsection (a) shall be computed without regard to any deduction allowed under subparagraph (A) ....

Internal Revenue Code of 1954, PUB. L. No. 591 Ch. 736; 83d Cong., 2d Sess.; H.R. 8300; 68 A Stat. 1.83.

361. Lindsey, supra note 256, at 1063. In 1962, Congress expanded the list of favored charitable foundations to include those that supported certain state colleges and universities. Id. at 1064.

362. See id.

363. See Crimm, supra note 32 , at 1113 .

364. See Lindsey, supra note 237, at 1063-64 (discussing the 1958, 1960, and 1962 amendments made to $\S 170$.) In $1958, \S 170(\mathrm{~b})(3)$ was amended to allow a succeeding year loss carry over of any disallowed charitable deduction while disallowing a double deduction for interest and charitable contribution. See id. at 1063. In 1960, Congress enacted a monthly $\$ 50$ charitable deduction for educational maintenance at the primary 
growing trend for establishing private foundations led to a sixties repeat of the fifties' populist investigations of private foundations. ${ }^{365}$ Because the fifties, the conservative populist message of foundation's supporting un-American activities did not produce the desired regulatory results; the populist movement returned to its Walsh Commission anti-industrialist economic message attacking "the arrogance and greed of a wealthy, mainly East Coast, elite." ${ }^{366}$ The populists finally made their mark at the decade's end.

Starting with his investigations in 1961, Congressman Wright Patman produced eight congressional reports on private foundation's activities, his first presented in 1962. ${ }^{367}$ His motivations consisted of a repeat of the fifties' populist message: foundations allowed the wealthy to abuse tax laws, obtain and maintain control over public corporations, speculate in and

level. See id. at 1063-64. In 1962, Congress expanded the allowable $30 \%$ deduction list of favored charitable foundations to include those that supported certain state colleges and universities while reducing the deduction to fair market value for contributed property. See id. at 1064 .

365. See Marsh, supra note 10, at 150-51; see also Crimm, supra note 32 , at 1113 n.131 (noting that Congressman Patman based the premise of his first speech attacking private foundations on their rapid growth).

366. Marsh, supra note 10, at 150; see Rambler, supra note 164, at 1372 (explaining that the congressional conservatives sought lobbying restrictions for foundations on the grounds that such foundations were supporting a policy against the Vietnam War, advocating the abolition of the House Un-American Activities Committee, and requesting the admission of China to the United Nations); see also Crimm, supra note 32, at 1112 (discussing the conflicts over private foundations that occurred during the $1950 \mathrm{~s}$ ).

367. C. Eugene Steuerle \& Martin A. Sullivan, Toward More Simple and Effective Giving: Reforming the Tax Rules for Charitable Contributions and Charitable Organizations, 12 AM. J. TAX POL'Y 399, 423 (1995). Congressman Wright Patman was Chair of the House Select Small Business Committee. Description of Income Tax Provisions Relating to Private Foundations, Joint Committee on Taxation JCS-31-83 June 24, 1983 at pg. 3-4. Congressman Patman's 1960s reports included: (1) Tax-Exempt Foundations and Charitable Trusts: Their Impact on Our Economy, Chairman's Report, House Select Committee on Small Business, Committee Prints, Cong. Sess. 87-2, Dec. 31, 1962; (2) Tax-Exempt Foundations and Charitable Trusts: Their Impact on Our Economy, Installment No. 2. Subcommittee Chairman's Report, House Select Committee on Small Business, Committee Prints, Cong. Sess. 88-1, Oct. 16, 1963; (3) Tax-Exempt Foundations and Charitable Trusts: Their Impact on Our Economy, Installment No. 3. Subcommittee Chairman's Report, House Select Committee on Small Business, Committee Prints, Cong. Sess. 88-2, Mar. 20, 1964; (4) Tax-Exempt Foundations and Charitable Trusts: Their Impact on Our Economy, Installment No. 4. Subcommittee Chairman's Report, House Select Committee on Small Business, Committee Prints, Cong. Sess. 89-2, Dec. 21, 1966; (5) Tax-Exempt Foundations and Charitable Trusts: Their Impact on Our Economy, Installment No. 5. Subcommittee Chairman's Report, House Select Committee on Small Business, Committee Prints, Cong. Sess. 90-1, Apr. 28, 1967; (6) Tax-Exempt Foundations and Charitable Trusts: Their Impact on Our Economy, Installment No. 6. Subcommittee Chairman's Report, House Select Committee on Small Business, Committee Prints, Cong. Sess. 90-2, Mar. 26, 1968; (7) Tax-Exempt Foundations and Charitable Trusts: Their Impact on Our Economy, Installment No. 7. Subcommittee Chairman's Report, House Select Committee on Small Business, Committee Prints, Cong. Sess. 91-1, June 30, 1969. 
manipulate the capital markets, and direct public policy. ${ }^{368}$ In 1962, Congress Patman issued his initial report critical on foundations and their activities, listing seventeen remedies, many of which were an expanded rehash of the recommendations of the 1916 Walsh Commission report. ${ }^{369}$ The remedies included: (1) halting any new establishment of private foundations; (2) a twenty-five year limit on the life of private foundations; (3) establishment of a national regulatory agency for foundations; (4) active enforcement by Treasury of the self-dealing rules; (5) a restriction on engaging in business activities; (6) restriction on borrowing or lending money; (7) a three percent share ownership restriction of any corporation; (8) a restriction on share voting; (9) controlling donors' charitable deduction denied until corresponding contributions spent for charitable purposes; (10) requiring all contributions and capital gains be spent currently; (11) taxing foundations' income at twenty percent; and (12) forbidding voter registration drives. ${ }^{370}$

In the opening statements of his first report, Congressman Patman predicted that "the economic life of our Nation has become so intertwined with foundations that unless something is done about it they will hold a dominant position in every phase of American life." ${ }^{971}$ In Chapter one, the report began by summarizing that that Treasury should impose an immediate moratorium on foundations' tax exemption based on the following reasons:

\section{Laxness and irresponsibility on the part of the}

368. See Crimm, supra note 32, at 1113-14; Marsh, supra note 10, at 150-51; Rambler, supra note 164, at 1372. Potential control of public policy and control of the economy can be chalked up to the issue being raised by James Madison and Ulysses Grant. Dr. Eliot dealt with potential tax abuse in the Massachusetts Tax Commission report. See supra Part VII(B).

369. See House Select Comm. on Small Business, 87Th Cong., Tax-Exempt Foundations and Charitable Trusts: Their Impact on Our Economy 1, 133-134 (Comm. Print 1962) [hereinafter PATMAN REPORT No. 1]. Chairman Patman specifically recalled that, "[a]s far back as 1916 , we were amply warned by the Walsh Committee of the abuses which might well flow from the creation of these privileged, tax-exempt entities. ..." Id. at 1.

370. See PATMAN REPORT No. 1, supra note 369, at 133-34; see also Crimm, supra note 32 , at $1114 \mathrm{n} .134$ (noting that the recommendation against foundations supporting voter registration drives was in retaliation to the Ford Foundation's grant to support black voter registration which effected Cleveland's mayor election).

371. PATMAN REPORT No. 1, supra note 369, at Letter of Transmittal p. v. This proposition continued the 1916 Walsh Commission's claim against the control of the economy by the industrialists' foundations, again calling forth the original concerns of Presidents Madison and Grant and James Patton that exempt organizations would accumulate capital to the point of harming democratic institutions. See supra Parts VII(B), IX. 
Internal Revenue Service.

2. Violations of law and Treasury regulations by far too many of the foundations encompassed in our study.

3. The withdrawal of almost $\$ 7$ billion from the reach of tax collectors for taxable years 1951 through 1960. This amount represents the total receipts of only 534 out of an estimated 45,124 tax exempt foundations.

4. The rapidly increasing concentration of economic power in foundations which-in my view - is far more dangerous than anything that has happened in the past in the way of concentration of economic power.

5. Foundation-controlled enterprises possess the money and competitive advantages to eliminate the small businessman. ${ }^{372}$

In support of the alleged laxness of the I.R.S. toward auditing the regulatory violations, Chairman Patman listed numerous non-filing and non-reporting violations committed by substantial foundations, after which he pointing out that "[a]ny member of this body will recognize that infractions such as these by ordinary citizens would have the Internal Revenue Service pursing them in force. ${ }^{\text {"773 }} \mathrm{He}$ also presented numerous shortcomings in foundations' method of accounting used in their annual reports, focusing on the lack of uniform accounting procedures regarding characterization of capital gains and income, asset valuation, and year end..$^{374}$

Regarding his third justification against the tax exemption, he put forward a tax equity argument as well as a subsidy without representation argument. $\mathrm{He}$ stated the moderate income workers, farmers, and small businessmen were bearing an inequitable tax burden because the wealthy's income was growing exempt in foundations. ${ }^{375}$ He put forward that the over

372. PATMAN RePORT No. 1, supra note 369, at 1.

373. Id. at $3-4$.

374. Id. at $5-7$.

375. See id. at 2. This argument merely continued the argument of inequitable burden raised in the $1850 \mathrm{~s}, 1870 \mathrm{~s}$, and in the 1894 congressional debate by Senators 
\$1billion received by 534 tax exempt foundations in 1960 was substantially more than that of the largest fifty banks and that the charitable deduction led to only one-third of the national income being taxed. ${ }^{376}$ Also, rather than subsidizing charitable activities, the tax exemption was funding the foundation's antidemocratic propaganda, as well as speculative financial activities and anti-competitive business practices. ${ }^{377}$

In support of his fourth argument relating to concentration of wealth, Patman included a list of significant companies in which foundations owned ten percent or more of the stock, and that also either combinations of foundation stock and owner stock or convertible stock led to further control. ${ }^{378}$ Regarding his argument based on unfair competitive advantages, Patman presented the example of how for profit laboratories and engineering firms operated at a loss because exempt research companies bid their equipment at or below cost as well as specifically excluding the profit amount from the final bid price. ${ }^{379}$

In the report's seventeen recommendations, Patman presented the arguments of Julius Rosenwald for the twenty-five year establishment limitation, being that limited life would end the foundational bureaucracy, force accumulated funds to be spent on charitable purposes, and re-distribute the control of American industry. ${ }^{380}$ His recommendations ended with a call for further reporting requirements, including: (1) publicly publishing exemption applications and administrative decisions; (2) publicly publishing foundations' tax returns; (3) a national registry of public foundations; (4) disclosure of expenditure for legislative or political activities, and advertising; and (5) description of all activities in which commercial organizations are also engaged. ${ }^{381}$

The second Patman Report, presented October 16, 1963, started with an attack against Treasury: "It is evident that nonfeasance on the part of Treasury officials has fostered tax-free commercial activities, violations of law and Treasury regulations, and tax avoidance through the device of foundations. ${ }^{382}$ The

Peffer and Higgins.

376. See id. at 4

377. See id. at 2, 4, 9-13.

378. PATMAN REPORT NO. 1, supra note 369 , at 8-9.

379. See id. at 9-12.

380. See id. at 133; Brody, supra note 11, at 921-22 (noting that the philanthropist Julius Rosenwald, Sears, Roebuck founder, upon establishing his foundation with a twenty-five year life, argued in the 1920s that perpetual endowments created a harm to society, freezing funds from the present requirements of charitable institutions).

381. See PATMAN REPORT No. 1, supra note 369, at 135.

382. House Select Comm. ON Small Business, 88Th Cong., TaX-Exempt Foundations and Charitable TRUSTs: THEIR IMPACT ON OUR ECONOMY (SECOND Installment), at Letter of Transmittal p. III (Comm. Print 1963) [hereinafter PATMAN 
Report focused on the unrelated but tax exempt business activities undertaken by foundations, including security dealing, business and credit brokers, and banking and mortgage activities, and the corresponding self-dealing and inurement resulting there from. ${ }^{383}$ Similar to the first report, Patman provided numerous examples of alleged abuse by a few large foundations. ${ }^{384}$ Patman blamed this non-compliance on the fact that the I.R.S. did not have the zeal to pursue the violations, evidenced by the fact that four hundred thirty-three of the five hundred, forty-six foundations under the Committee's review had not been audited. ${ }^{385}$

However, the 1962 and 1963 Patman reports produced the same legislative results as its predecessor 1916 Walsh Commission report. ${ }^{386}$ Rather than ushering in a wrath of restriction against private foundations, in 1962 and 1964 Congress further expanded the class of favored foundations that qualified for the full thirty percent charitable deduction. In 1962, Congress expanded the class to include foundations that supported state colleges and universities, and in 1964, foundations that received substantial government or general public support. ${ }^{387}$ The 1964 Act further liberalized the charitable

REPORT NO. 2].

383. See id. at III-IX.

384. See id. at $12-83$.

385. See id. at 5 .

386. See Troyer, supra note 279, at 55 (suggesting that Congressman Patman's Reports may not have attracted congressional attention because much of Congress, including the key tax writing committee members, "detested" him).

387. See Lindsey, supra note 237, at 1064; Marsh, supra note 10, at 149; see the Senate Report, PUB. L. No. 88-272, Revenue Act of 1964, (S. REP. No. 830, 88th Cong., 2 d Sess. 59 1964) (Lexis):

For any of the nongovernmental organizations to qualify for the additional 10-percent deduction referred to above, they must normally receive a substantial part of their support from a governmental unit or from direct or indirect contributions from the general public. "Support" for this purpose does not take into account income received by the organization from exercise of its exempt function. The reference to direct or indirect contributions from the general public prevents what are generally termed private foundations from qualifying for this additional 10-percent deduction. To qualify, the organization must receive support from at least a representative number of persons within the community concerned.

Types of organizations which generally will in the future qualify for this additional 10-percent deduction are those publicly or governmentally supported museums of history, art, or science, libraries, community centers to promote the arts, organizations providing facilities for the support of an opera, symphony orchestra, ballet, or repertory drama, and organizations such as the American Red Cross, United Givers Fund, etc. 
deduction by enacting a five-year carry forward period for any unused deduction exceeding the thirty percent threshold in the contribution year. ${ }^{388}$ The 1964 policy justification for expanding the qualifying foundation list was to increase the "immediately spendable contributions" to such organizations. ${ }^{389}$

However, potentially partly influenced by the numerous allegations presented in Patman's reports, the 1964 Act restricted the 1954 provision that removed the deduction ceiling for taxpayers who gave more than ninety percent of their income to charity in eight out of ten years. ${ }^{390}$ Congress limited this provision to donations made to favored foundations qualifying under the newly expanded criteria for the thirty percent deduction, thus constricting the substantial deductible donations made by the wealthy to their private foundations. ${ }^{391}$ The Senate

388. Williams \& Moorehead, supra note 241, at 2103.

389. Rambler, supra note 164, at 1371. But see Troyer, supra note 279 , at 55 (stating that the Ways and Means Committee, because of its members general "dissatisfaction" and "suspicion" with private foundations, specifically excluded them from the $30 \%$ deduction); S. Report, PUB. L. No. 88-272, Revenue Act of 1964, S. REP. NO. 88-830, Jan. 28, 1964 at 1731. (S. REP. NO. 830, 88th Cong., 2d Sess. 1964) (stating that "[t]hese latter types of organizations frequently do not make contributions to the operating philanthropic organizations for extended periods of time and in the meanwhile use the funds for investments."); see also Bittker \& Rahdert, supra note 163, at 337-38 (presenting that the 1964 legislation's discrimination against private non-operating foundations may have embodied three distinct justifications. First, Congress may have considered that non-operating foundations make fewer continuing commitments, thus better able to manage financial planning. Second, publicly supported foundations address immediate social needs. Thirdly, public support for a foundation expresses public endorsement of it.).

390. See Troyer, supra note 279, at 55-56; Hall, supra note 262, at 14 (stating that the eventual amendment to this provision restricting its application started with an intense lobbying of the Senate Finance Committee by the Rockefeller family to expand the provision's benefits). While the Senate Finance Committee originally agreed to expand the provision to encourage contributions by the wealthy, the resulting backlash from other Senate and House members resulted in the inevitable limitation of the provision. Troyer, supra note 279, at 58 (quoting Senators Russell Long, Albert Gore, and Eugene McCarthy from the Senate Finance Committee dissent against Rockefeller's proposed expansion of the deduction, "at present rates of establishment, substantial control of our economy may soon rest in the "dead hands" of such organizations, endangering "the free choices presented by the marketplace and by the democratic processes of a free government, free economy, and a free society."); see also John G. Simon, Private Foundations as a Federally Regulated Industry: A Time for a Fresh Look?, 27 Exempt Organization Tax Rev. 66, 70-1 (Jan. 2000) (stating that Senator Gore compared the power of foundations to sixteenth century English churches). See supra Part VII(B) (noting that this dissent aligns closely to that raised by Presidents Madison and Grant and James Parton); see also supra Part III. Henry VIII seized the Catholic Church and colleges properties and put forward the Statute of Uses for the similar reasons that substantial control of England rested in the dead hands of the Church and that the Catholic Church, through its colleges, affected the public policy.

391. S. REP. No. 830 Part 2; 88th Cong.. 2d Sess.; H.R. 8363. Supplemental Report Technical Explanation Of The Bill [To Accompany H.R. 8363] January 31, 1964, 1964 U.S.C.C.A.N. 1673 at $1732-33$ :

10. Denial of unlimited charitable contributions deduction with respect 
Finance Committee justified this discrimination with two arguments. ${ }^{392}$ First, the Finance Committee stated that private foundations accumulated their income, thus thwarting the charitable expenditure justification for expanding the qualifying foundations criteria. Second, the Finance Committee stated that the benefits of the control of private foundation investments inured to the principal contributors.

\section{The TREASURY REPORTS}

In 1964, the Senate Finance Committee requested Treasury to undertake its own study of foundations. ${ }^{393}$ Treasury limited its

to gifts to private foundations...

(b)...With respect to future years, the unlimited charitable contribution deduction will take into account charitable contributions to: churches; schools; hospitals; specified medical research organizations; certain organizations affiliated with State colleges or universities; Federal, State, or local governmental units, if the contribution or gift is made for exclusively public purposes; and charitable contributions generally to religious, charitable, scientific, literary, or educational organizations or those for the prevention of cruelty to children or animals. However, in this latter case, the charitable organization must receive a substantial part of its support from a governmental unit or from direct or indirect contributions from the general public.... The reference to direct or indirect contributions from the general public is designed to prevent gifts to private foundations from qualifying for this unlimited deduction. To qualify, the organization must receive support from at least a representative number of persons within the community concerned.

392. S. REP. No. 830 Part 2; 88th Cong. 2d Sess.; H.R. 8363. Supplemental Report Technical Explanation of the Bill [To Accompany H.R. 8363] January 31, 1964, 1964 U.S.C.C.A.N. 1673 at 1732 :

10. Denial of unlimited charitable contributions deduction with respect to gifts to private foundations...

(b) General reasons for provision. - Your committee has added a provision to the bill making the unlimited charitable contribution deduction available only with respect to contributions to publicly supported organizations for much of the same reasons that both the House and your committee only make the extra 10-percent deduction available in the case of these organizations. Your committee believes that the special advantage of the unlimited charitable contribution deduction should not be made available in the case of these private foundations because frequently contributions to foundations do not find their way into operating philanthropic endeavors for extended periods of time. In the meanwhile, the funds are invested and the advantages arising from control of these investments are likely to inure to the principal contributors to the foundations. Thus, your committee concluded that if the 20- or 30-percent limitations with respect to charitable giving are to be removed for those desiring to make large contributions there should be no question that the bulk of the funds involved, within a reasonable period of time, are devoted to the charitable and philanthropic purposes.

393. Steuerle \& Sullivan, supra note 367 , at 423. 
study to private foundations and non-exempt trusts, defining a private foundation as an organization per section 501(c)(3) other than publicly or governmentally supported organizations, churches, schools, organizations to test public safety and finally, non-exempt trusts that pay or permanently set aside amounts for certain charitable purposes. ${ }^{394}$ Treasury reviewed a sample of thirteen hundred foundations' returns, including all foundations with assets of more than ten million dollars, and consulted various interested parties including the Internal Revenue Service, Justice Department, a group of foundation representatives, and a group of attorneys with special experience and expertise in the field. ${ }^{395}$ Presented in 1965, the Treasury Report began Part 1 by examining the relationship of private foundations and the government:

Private philanthropic organizations can possess important characteristics which modern government necessarily lacks. They may be manycentered, free of administrative superstructure, subject to the readily exercised control of individuals with widely diversified views and interests. Such characteristics give these organizations great opportunity to initiate thought and action, to experiment with new and untried ventures, to dissent from prevailing attitudes, and to act quickly and flexibly. Precisely because they can be initiated and controlled by a single person or a small group, they may evoke great intensity of interest and dedication of energy. These values, in themselves, justify the tax exemptions and deductions which the law provides for philanthropic activity. ${ }^{396}$

Commenting on foundations unique role within society, Treasury found: "Private philanthropy plays a special and vital role in our society. Beyond providing for areas into which

394. Staff of Senate Comm. on Finance, 89Th Cong., Treasury Department on PRIVATe Foundations at 3 (Comm. Print 1965) [hereinafter 1965 Treasury RePorT]. Four years later, Congress included a slightly expanded class of non-private foundations in codifying what did not constitute a private foundation. See I.R.C. $\$ 501$ (1969). Treasury's definition merely encapsulated the previous definition and classes included since the 1943 Act regarding which foundations Congress did not subject to the more onerous reporting requirements and allowed to take advantage of the full $30 \%$ charitable deduction. $I d$.

395. Troyer, supra note 279 , at 56.

396. 1965 TREASURY REPORT, supra note 394, at 12. 
government cannot or should not advance (such as religion) ... , private foundations are "available even to those of relatively restricted means, they enable individuals or small groups to establish new charitable endeavors and to express their own bents, concerns, and experience. In doing so, they enrich the pluralism of our social order. ${ }^{\text {"397 }}$ Finally, turning to private foundation's role within the realm of charity:

Private foundations have also preserved fluidity and provided impetus for change within the structure of American philanthropy. Operating charitable organizations tend to establish and work within defined patterns. The areas of their concern become fixed, their goals set, their major efforts directed to the improvement of efficiency and effectiveness within an accepted framework. Their funds are typically consigned to definite and growing - budgets. The assets of private foundations, on the other hand, are frequently free of commitment to specific operating programs or projects; and that freedom permits foundations relative ease in the shift of their focus of interest and their financial support from one charitable area to another. New ventures can be assisted, new areas explored, new concepts developed, new causes advanced. Because of its unique flexibility, then, the private foundation can constitute a powerful instrument for evolution, growth, and improvement in the shape and direction of charity. ${ }^{398}$

Next, the Treasury Report countered the three primary allegations against foundations, also raised in Congressman Patman's Committee hearings. ${ }^{399}$ As to the first allegation that foundations delay the expenditure of contributions on charitable activities, Treasury concluded that this criticism could be dealt with by specifically tailored regulation. ${ }^{400}$ Regarding the allegation that the foundation sector had grown to represent too significant a portion of the national economy, Treasury did not

397. $I d$.

398. Id.

399. Williams \& Moorehead, supra note 241, at 2106; 1965 Treasury Report, supra note 383 , at 12

400. 1965 TREASURY REPORT, supra note 394, at 5 . 
find a factual basis. Treasury stated that foundations were themselves dealing with the allegation that they represent a dangerous concentration of economic and social power. ${ }^{401}$ Finally, the Treasury reported that it had found serious abuse only in a minority of foundations. ${ }^{402}$

In Part II, Treasury presented six remedies to counter the general criticisms associated with the intimate structural ties among foundations, their donors and the donor's relations, and affiliated for-profit corporations. ${ }^{403}$ First, Treasury examined its enforcement of the 1950 arm's length standard. ${ }^{404}$ Listing twelve examples, it concluded that the standards application was tenuous and costly, resulting from the ambiguous terminology of the regulation. ${ }^{405}$ Thus Treasury, like the Ways \& Means Committee of 1950, suggested that all self-dealing be prohibited, rather than regulated at arm's length, but for reasonable compensation for services performed ${ }^{406}$ Also, Treasury proposed prohibitions against three specific financial transactions: borrowing for investments; making loans; and speculative trading and investments, though it concluded that only a small group of foundations undertook these. ${ }^{407}$

Second, Treasury presented a tailored regulation for the general allegation that foundations delay the donor's charitable expenditures, though recognizing that in practice but a few foundations did not pay out substantially all their income. ${ }^{408}$ Treasury noted the assertion that the delay could be justified because it allowed uncommitted funds that could be deployed

401. Williams \& Moorehead, supra note 241, at 2106.

402. 1965 TREASURY REPORT, supra note 394, at 14.

403. Crimm, supra note 3 , at 789 . The 1965 Treasury Report in part III dealt with specific tax planning concerns, such as tax-free bailout of corporate earnings, not discussed herein.

404. 1965 TREASURY REPORT, supra note 394, at 6, 15-23.

405. Id. at 6,18 .

406. Id. at 21 ; see $i d$. at 18,23 (Treasury also justified the ban in that in Commonwealth trustee fiduciary law, trustees are barred from dealing with the trust as well as that the loss of opportunity to employ funds for personal purposes would result in their being used for charitable purpose). Congress adopted this recommendation in the 1969 Act, I.R.C. \$ 4941. See CONF. REP. No. 782, 91st Cong., 1st Sess. 1969, 1969 U.S.C.C.A.N. 2391, at 2392-93.

407. Williams \& Moorehead, supra note 241 , at 2100 (citing 1965 TREASURY REPORT, supra note 394, at 45-54); see Crimm, supra note 3 , at 789.

408. 1965 TREASURY REPORT, supra note 394, at 23-30. The Treasury noted that in 1962 , only $25 \%$ of foundations did not charitably distribute all their income, and that many of that $25 \%$ had distributed substantial portions of their income or could have been included in the 75\% had their 1962 ear-marked distributions actually paid out in 1963 been counted. Id. However, because most foundations met the requirement of the distribution of their earned income, the Treasury concluded that such a requirement would affect few of them adversely. $I d$. at $26-27$. 
from one charitable area to another, as well as creating an even larger endowment for future charitable use. ${ }^{409}$ However, the Treasury concluded that the non-operating foundation's long period of retention of both contributions and the investment income in relation thereto did not align with the policy of forgoing government revenue in exchange for charitable expenditure toward the public welfare. ${ }^{410}$ It noted that the current rule against accumulation did not even address the accumulation of contributions or the growth in the actual asset base. ${ }^{411}$ Treasury concluded that enforcement of the current rule, like enforcement of the present self-dealing arm's length rule, was administratively burdensome and costly. ${ }^{412}$

Thus, addressing the accumulation of both income and asset base and seeking to enforce the policy of exemption for charitable expenditure, Treasury proposed that non-operating foundations be required to distribute annually the greater of either their annual income or a minimum fixed percent of their assets, suggested to be in a range of three to three-and-a-half percent. ${ }^{413}$ The minimum fixed percent proposal range evolved from what Treasury concluded would be the equivalent income earned by a comparable organization's endowment, such as a University. ${ }^{414}$ Treasury recommended that Congress require non-operating foundations' annual distribution be only to publicly supported charitable organizations, privately supported operating organizations, direct expenditure for charitable purpose and the purchase of assets used for charitable activities. ${ }^{415}$

Third, Treasury turned its attention to foundations' unrelated businesses and the criticism of donor's continued control of family business interests. ${ }^{416}$ Treasury noted three concerns: (1) unfair competitive, tax exempt advantage; (2) poor investment return; and (3) the aggravation of the issues of selfdealing and lack of charitable expenditure.

Regarding unfair advantage, Treasury noted four issues. First, a tax exempt's taxable businesses could reduce their tax base through selling assets to the tax exempt entity, thereafter

409. Id. at 24,28 .

410. Id. at 28 .

411. See Troyer, supra note 279, at 57.

412. Id.

413. 1965 TREASURY REPORT, supra note 394, at 28-29. Congress adopted this recommendation in the 1969 Act, I.R.C. $\$$ 4942. See CONF. REP. No. 782, 91st Cong., 1st Sess. 1969, 1969 U.S.C.C.A.N. 2391 at $2395-96$.

414. 1965 TREASURY REPORT, supra note 394, at 28.

415. Id. at $26-27$.

416. Troyer, supra note 279 , at 57. 
making deductible payments to the tax exempt entity, reducing the business' earnings and creating tax free income for the foundation. ${ }^{417}$ Second, because donations were deductible, a foundation's founder could contribute deductible, before tax dollars, to the foundation and thereafter capitalize his businesses, whereas ordinary taxpayers invested with nondeductible, after-tax dollars. ${ }^{418}$ Third, a foundation's reserves grow tax free allowing it "to subsidize its businesses during periods of difficulty and to expand them during periods of growth." ${ }^{119}$ Fourth, because foundation's businesses lack a shareholder's demand for distributed profits, they can more aggressively invest in modernization and expansion. ${ }^{40}$

Regarding poor investment return, Treasury performed a survey regarding foundation holdings of more than twenty and fifty percent of a company. ${ }^{421}$ Treasury concluded that in both instances, the average yields were far below the Dow Jones average, with a significant portion of the holdings having no yield, with no corresponding benefit in share appreciation. ${ }^{422}$ Treasury determined that these substantial holdings delayed charitable expenditure, thus were not aligned with the policy of providing for social welfare. ${ }^{423}$

Finally, Treasury argued that a foundations involvement in multiple businesses required the foundation's directors devote their attention to the businesses rather than the exploration and development of alternative social solutions, the primary justification for their favored tax position. ${ }^{424}$ Consequently, Treasury stated: "Business may become the end of the organization; charity an insufficiently considered and mechanically accomplished afterthought." ${ }^{\text {,25 }}$ Thus, continued the report, the foundation's directors become indistinguishable from a self-perpetuating public company's management. ${ }^{426}$

Therefore, Treasury recommended that foundations be limited to a twenty percent proportional ownership of a corporation conducting business not substantially related to the

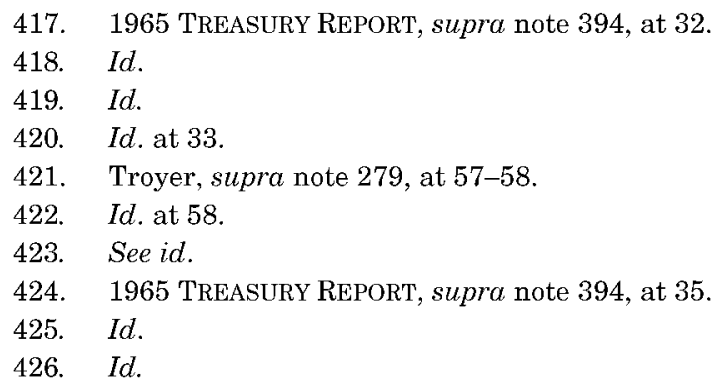


exempt purpose. ${ }^{427}$ In conjunction with this recommendation, to deal with the criticism levied at family foundations receiving dividend stock while the family retained the controlling voting stock and obtained a deduction, Treasury proposed the deferral of the controlling donor's deduction until either the donor relinquished control of the business or the charity disposed of it. $^{428}$

In concluding these remedies for the major abuses, Treasury suggested that twenty-five years after establishment, Congress mandate that the foundation's governing body should consist of no more than twenty-five percent of donors and their relations so that the foundation could acquire new perspectives, stemming institutional bureaucracy. ${ }^{429}$ Ending the Report, Treasury called for Congress to establish civil penalties for non-compliance with filing and reporting requirements because the current sanctions called for criminal sanctions, to severe for implementation in most cases. ${ }^{430}$

On December 21, 1966 Patman released his fourth Report, continuing the themes of the previous ones. ${ }^{431}$ Patman's criticisms included: (1) foundations' losing funds in speculative investments rather than using them for charitable expenditure; ${ }^{432}$ (2) greater than fifty percent of income accumulated rather than used for charitable expenditure; ${ }^{433}$ (3) approximately ten percent of receipts expensed rather than used for charitable expenditure ${ }^{434}$ (4) improper charitable expenditure for personal and political use ${ }^{435}$ and (5) tax dodging. ${ }^{436}$ Patman claimed his committee's prodding led to two results: (1) the 1965 Treasury Report, but that the report represented only a minimum effort to curb foundations' abuses; and (2) seven foundation audits leading to tax assessments. ${ }^{437}$

427. Id. at 36. Treasury recommended that Congress continue the exceptions granted under the 1950 Act, such as used clothing stores and employee cafeterias. Congress adopted this recommendation in the 1969 Act, I.R.C. $\$ 4943$. See CONF. REP. No. 782, 91st Cong., 1st Sess. 1969, 1969 U.S.C.C.A.N. 2391 at $2396-97$.

428. 1965 TREASURY REPORT, supra note 394, at 41-42.

429. Id. at 56-57. Treasury's approach was probably in response to the persistent calls for the termination of a foundation's life after a period of time.

430. Id. at 64 .

431. House Select Comm. on Small Business, 89Th Cong., Tax-Exempt Foundations AND ChaRITABle TRUsts: THEIR IMPACT ON OUR ECONOMY (Fourth Installment) (Comm. Print 1966) [hereinafter Patman RePort No. 4].

432. Id. at 2 .

433. Id. at 3 .

434. Id.

435. Id. at $4-5$.

436. Id. at 6 .

437. See PATMAN RePORT No. 4, supra note 431, at 10. 


\section{PETERSEN COMMISSION}

In response to the 1965 Treasury Report, John D. Rockefeller, III commissioned Peter G. Peterson to chair an independent investigation of foundations (the "Petersen Commission"). ${ }^{438}$ Though it was published in 1970, the Petersen Commission delivered its findings and recommendations to Congress during the 1969 hearings. ${ }^{439}$ The Petersen Commission was charged with providing an evaluation report and with making recommendations regarding the role for foundations in society. The Petersen Commission chose to examine the twentytwo thousand grant-making foundations that received their contributions from one person or small group of persons, excluding operating and publicly supported foundations. ${ }^{440}$

In its two hundred, seventy-seven page report, the Petersen Commission first stated the popular criticisms of foundations, that they:

(1) were tax avoidance vehicles for the wealthy;

(2) represented the Ivy League establishment's perpetual concentration of power through self perpetuating boards;

(3) were heavily involved in politics, not charity;

(4) promoted extremist ideology, be it left or right;

(5) squandered their charitable money on high expense accounts and salaries; and

(6) accumulated their earnings rather than spent them on charity. ${ }^{441}$

The Petersen Commission next charged that no data and information had been collected to either support or refute the criticisms; finding that no Committee, Commission, or government agency had undertaken relevant studies to determine the validity of criticisms. ${ }^{442}$ Instead, it found that the

438. Crimm, supra note 32 , at $1117-18$

439. Id. at 1118 .

440. See PETERsEn CoMmission, supra note 313 , at 39,48 .

441. Id. at 4 .

442. See id. 
criticisms were drawn from mere anecdotes that they had not been checked for validity. ${ }^{43}$

The Petersen Commission responded that "The main financial abuses charged against foundations spring, in essence, from too clever an exploitation of their advantages.... [a] donor's ability to control a foundation is the precondition that makes financial abuses potentially possible." ${ }^{p 44}$ The potential abuses are two fold. First, the donor may overvalue donations to receive a greater tax deduction. ${ }^{445}$ Second, the donor may receive financial benefits from use of the foundation's assets. ${ }^{446}$

The Petersen Commission undertook two studies to determine the extent of tax avoidance abuse. ${ }^{447}$ First, it examined five hundred Form 990-A information returns upon which all potential self-dealing transaction must be reported. ${ }^{448}$ Secondly, it employed Arthur Andersen to survey anonymously two hundred, twelve accountants concerning their impression of self-dealing among small foundations. ${ }^{49}$ The data evidenced that in only approximately ten percent of both large and small foundations did any potential self-dealing transactions occur. ${ }^{450}$ Thus, the Petersen Commission concluded that while some selfdealing abuse occurs, it is in very limited situations. ${ }^{451}$ Regarding abusive administrative expenses, the results of the Arthur Andersen survey found that only five percent of accountants perceived potential abuse, and that on average, administrative expenses were only $2.9 \%$ of grant expenditures. ${ }^{452}$ Finally, in grant making, only eight percent of accountants perceived potential abuse of grants being made in favor of donors or their related parties. ${ }^{453}$

The Petersen Commission next turned to the two primary policy criticisms of foundations. From a tax policy perspective, tax incentives for charitable donations are inequitable and create elitism to the detriment of democratic pluralism. ${ }^{454}$ Wealthier taxpayers in higher tax brackets cost the government more in

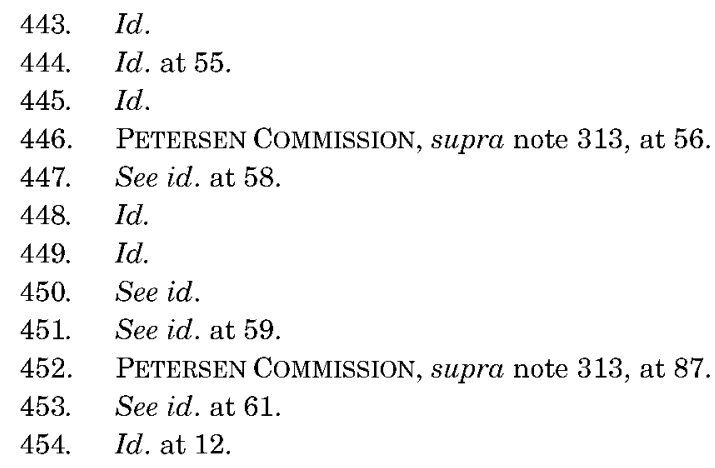


subsidy for each tax dollar donated than lower bracket taxpayers. ${ }^{455}$ Correspondingly, wealthier taxpayers have a lower cost of donation. By example, a dollar donated by a taxpayer in a thirty-five percent costs the government thirty-five cents and that taxpayer the remainder after tax of sixty-five cents; whereas the same dollar donated from a taxpayer in a fifteen percent bracket costs the government fifteen cents and the taxpayer eighty-five cents. Elitism results from the lost government revenue that would have been spent by the elected representatives but instead is allocated by private parties. ${ }^{456}$ Secondly, from the economic policy perspective, the Petersen Commission noted that critics attacked the claim that private charity is more efficient and more committed than government. ${ }^{457}$ Critics claimed that efficiency is reduced by private actors pursuing similar, redundant goals. Also, charitable expenditure is diverted to public relations and fund raising, activities unnecessary for government.

In response to these two criticisms, the Petersen Commission found that foundations perform a number of activities better than government as well as undertake activities that government cannot. ${ }^{458}$ Also, the Petersen Commission argued that these activities are a valuable and necessary element of public service. ${ }^{459}$ First and foremost, the Petersen Commission concluded that foundations provided the venture capital and commercial planning to create social laboratories from which new ideas and social innovations can be tested. ${ }^{460}$ Second, because foundations acted as private parties, they operated by the efficiency and risk standards of the commercial sector. ${ }^{461}$

Regarding social programs, the Petersen Commission put forward that foundations may pick controversial or sensitive topics to study that government, due to political minorities, may not. ${ }^{462}$ Examples included the study of illegal drugs and public school assessment programs. ${ }^{433}$ Also, foundations may choose a community to experiment with, and collect results from, without the political pressure to roll out program expenditure to all

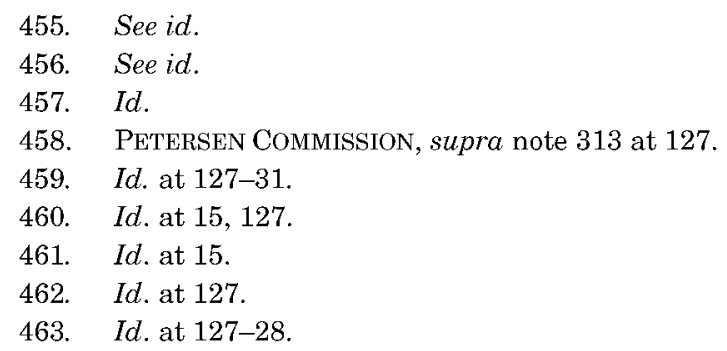


congressional districts. ${ }^{464}$ Foundations may perform long-term studies in a selected roll out of communities, whereas elected officials are subject to producing results by the upcoming election. ${ }^{465}$ Foundations have the flexibility to undertake more costly approaches to issues as well as quickly write off programs that do not achieve results. ${ }^{466}$ Finally, foundations provide a check for and against government by providing the required capital to study current government programs. ${ }^{467}$

The Petersen Commission recommended a few items for foundations to employ in order to improve their efficiency and public image. In addressing efficiency, the recommendations included forming foundational associations for communication and sharing of information, as well as smaller foundations that cannot afford full time staff hiring outside experts as consultants. ${ }^{468}$ In addressing public perception, it suggested that foundations consider relocating from New York and expanding their boards beyond Northeast members. ${ }^{469}$

The Petersen Commission recommended that government expand tax incentives to increase charitable contributions, especially amongst the non-wealthy. ${ }^{470}$ The result, it proposed, would democratize philanthropy more and also make up the deficits of what society requires of philanthropic expenditure. The Commission agreed in principle with varying refinements of the 1969 reform, including expanded reporting, minimum distribution and prohibition on self-dealing transactions. ${ }^{471}$

\section{THE 1969 ACT}

In January 1969, Treasury Secretary Joseph Barr testified to Congress about the broad tax avoidance by wealthy taxpayers. ${ }^{472}$ This testimony, coupled with the 1965 Treasury Report and publicity garnered by Congressman Patman's continuing crusade, led to congressional mistrust and action against private foundations. ${ }^{43}$ The 1969 Tax Reform House Report began with an argument that the tax system created an inequitable result:

\footnotetext{
464. PETERSEN COMMISsion, supra note 313, at 127.

465. $I d$.

466. Id. at $127-28$.

467. Id. at 129 .

468. See id. at 131-32, 134-35.

469. See Petersen Commission, supra note 313 , at 132.

470. See id. at 145 .

471. See id. at $147-59$.

472. See Troyer, supra note 279 , at 59 .

473. See id. at 61 .
} 
Increasingly, in recent years taxpayers with substantial incomes have found ways of gaining tax advantages from provisions placed in the code primarily to aid some limited segment of the economy. In fact, in many cases they have found ways to pile one advantage on top of another. Your committee believes that this is an intolerable situation ... . Only by sharing the tax burden on a fair basis is it possible to keep the tax burden at a level which is tolerable for all taxpayers. ${ }^{474}$

The consequences of the inequitable result, the House reasoned, undermined the self-assessment system. ${ }^{475}$ In that the self-assessment system relied on the cooperation of taxpayers, inequitable result led to a loss of taxpayer confidence, which in turn caused a loss of morale and thus, non-compliance. ${ }^{476}$ As evidence of the inequitable result, the House presented testimony that one hundred, fifty-four taxpayers with income over two hundred thousand dollars, including twenty-one taxpayers with incomes over one million, did not pay tax. ${ }^{477}$ The itemized deduction constituted the primary cause of the wealthy's tax base reduction. ${ }^{478}$ Correspondingly, the charitable deduction played the most significant deduction, in particular the donation of appreciated property. ${ }^{479}$

Senate Finance Committee Chairman Russell Long, in his opening statement in support of the Conference Committee's bill, stated:

[W] hen the Finance Committee began public hearings on the Tax Reform Act of 1969 I referred to the bill as '368 pages of bewildering complexity.' It is now 585 pages. . . Much of this complexity stems from the many sophisticated ways wealthy individuals - using the best advice that money can buy-have found ways to shift their income from high tax brackets to low ones, and in many

474. H.R. REP. NO. 91-413 (1969), reprinted in 1969 U.S.C.C.A.N. 1645, 1645 . Note that the maximum federal tax rate in 1969 was $70 \%$. See id. at 1647 .

475. See id. at 1654 .

476. See id.

477. Id. at 1653 .

478. See id.

479. See id. at 1653-54. 
instances to make themselves completely tax free. It takes complicated amendments to end complicated devices. ${ }^{480}$

Approximately one-third of the 1969 Tax Reform Act dealt with tax exempt organizations, ${ }^{481}$ by which it codified the definitions of a private foundation and an operating foundation, enacted numerous regulations recommended by the 1965 Treasury Report that should apply to private foundations, levied an excise tax on private foundations to pay for the cost of I.R.S. tax exempt audits and expanded the reporting requirements and regulations of all tax exempt organizations, increased the charitable deduction to fifty percent but repealed the unlimited deduction and modified several provisions regarding the contribution of appreciated property. However, the Conference Committee rejected the Senate's proposal to limit the private foundation's tax exemption to forty years, the most damaging initiative from the perspective of the private foundations. ${ }^{482}$

\section{A. Codification of the Private Foundation Definition}

In that since the 1943 Act, the congressional practice had been to draw legislative distinctions regarding reporting, regulations, and the charitable deduction ceiling, between charitable foundations that fit into the favored classes and all other foundations, Congress' enactment of the private foundation definition constituted the mere formality of codifying that accepted practice. The House presented a default codification for private foundations, being all section 501(c)(3) organizations unless the organization fell into one of a defined set of favored classes. ${ }^{483}$ The favored class distinctions included: (1) organizations for which the thirty percent individual deduction applied $;^{484}(2)$ broadly publicly-supported organizations (including membership organizations); (3) supporting organizations operated exclusively for the benefit of one or more organizations

480. H.R. CONF. REP. NO. 91-782 (1969), reprinted in 1969 U.S.C.C.A.N. 2391, at 2490.

481. Williams \& Moorehead, supra note 241, at 2103-04.

482. See S. REP. No. 91-552 (1969), reprinted in 1969 U.S.C.C.A.N. 2027, at 2052.

483. See H.R. REP. NO. 91-413 (1969), reprinted in 1969 U.S.C.C.A.N. 1645, at 168586.

484. The deduction was subsequently increased to $50 \%$ under the 1969 Tax Reform Act. See S. REP. No. 91-552, reprinted in 1969 U.S.C.C.A.N. 2027, 2033. The organizations previously covering this class included "(1) churches, (2) schools, (3) hospitals, (4) fund-raisers for schools, (5) States and subdivisions, and (6) publicly supported charities." Id. at 2084. 
described above; and (4) public safety testing organizations. ${ }^{485}$ The second and third classes represented an expansion of the scope of the favored foundation class.

The House's second class of broadly publicly-supported organizations included as examples of intended beneficiaries of favored treatment symphony societies, garden clubs, alumni associations, Boy Scouts, and Parent-Teacher Associations. ${ }^{486}$ The proposed amendments to this class' definition established ceilings for these organizations' income and support regarding investments and disqualified persons to "insure that the organization is responsive to the needs of the public." ${ }^{487}$ First, no more than one-third of their annual support could be generated by gross investment income. ${ }^{488}$ Second, at least one-third of their support must be generated from sources other than disqualified persons such as from gifts, grants, contributions, membership fees, and gross receipts from admissions. ${ }^{489}$

The Senate proposal for this class, which was eventually accepted by the Conference Committee, expanded the definition and application of support to take into account income cycles and unusual grants, but limited the calculation of support by excluding the income derived from persons providing either more than $\$ 5,000$ or more than one-percent of that support. ${ }^{490}$ The Senate proposed expanding the definition of support to include amounts received from the exercise or performance of the exempt purpose except from unrelated business income. Finally, the Senate proposed that the level of public support should be tested annually based on a four-year running average, as well as allowing an exception from the strict application of this test for unusual grants or bequests. ${ }^{491}$

The House's third class of supporting organizations included as examples religious organizations other than churches, trusts that had been organized and operated for a specific school and were controlled in connection with such school, and university presses. ${ }^{492}$ The Senate expanded this class to include situations in which the supporting organization benefited more than one educational institution. ${ }^{493}$ The only justification for this new class

\footnotetext{
485. H.R. REP. NO. 91-413, at 1686.

486. Id.

487. Id.

488. See id.

489. Id.

490. See S. REP. No. 91-552 (1969), at 2086-87.

491. See id. at 2086 .

492. H.R. REP. No. 91-413, at 1686.

493. S. REP. NO. 91-552, at 2087.
} 
must be derived from the Senate's stated reason for the codification of the definition of a private foundation, that "certain other organizations presently in the 20-percent category generally do not give rise to the problems which have led to the restrictions and limitations described above." ${ }^{\not 94}$

\section{B. Codification of the Operating Foundation Definition}

The Senate justified delineating an "operating" foundation that lacked public support from the substantially grant making private foundation because the operating foundation employed most its income and assets directly in the exercise of its educational, charitable, and religious purposes themselves. ${ }^{495}$ This class of foundation received some of the favored benefits of non-private foundations and some of the disfavored treatment applying to private foundations, described further below. By example, the operating foundation qualified for the proposed fifty percent charitable deduction as well as to receive grants from private foundations, but suffered the proposed excise tax and required minimum distribution. ${ }^{496}$

The House proposed the definition for operating foundations as an organization for which the substantial portion of its income is spent directly upon the active conduct of its exempt purposes or functions and that it also met one of two alternative tests. ${ }^{497}$ To meet the first alterative test, the foundation employed substantially more than half its assets toward its exempt activities or functionally related business. ${ }^{498}$ To meet the second alterative test, the foundation either received substantially all of its support from a minimum of five independent exempt organizations of which no one tax exempt organization contributed more than twenty-five percent of that support, or

494. Id. at 2084; see Rambler, supra note 164, at 1377-78 (noting that the 1969 Act's hearings did not address the subject of the new class of supporting organizations).

495. See S. REP. No. 91-552, at 2088; H.R. REP. No. 91-413, at 1687. The "operating" foundation was first described in the 1964 legislation in that it qualified for the unlimited charitable contribution deduction but not for the $30 \%$ deduction. See Troyer, supra note 279 , at 55 .

496. See S. REP. No. 91-552, at 2088.

497. H.R. REP. NO. 91-413, at 1687. The House added that a substantial portion of income generally meant $85 \%$ of the foundation's income. Id. at 1688 .

498. See id. at 1687 . The House stated that $65 \%$ qualified as employing substantially more than $50 \%$ of the foundation's assets. Id. The House included specific examples of organizations that met this first alternative test, being "Callaway Gardens (a horticultural and recreational area for the use of the public at Pine Mountain, Georgia), Colonial Williamsburg [the Inn and Lodge at Colonial Williamsburg are separately incorporated taxable entities, but are owned by the foundation for the convenience of the general public visiting Williamsburg] and Jackson Hole [which operates functionally related business in connection with public parks and its exempt purposes]." Id. at 1688 . 
received substantial support from the general public. ${ }^{499}$

The Senate included a third alternative test to address situations in which a small endowment cannot meet the income needs of an operating foundation's personal services, presenting examples of Longwood Gardens, Sleepy Hollow Restoration, and research organizations. ${ }^{500}$ To meet this third alternative test, the foundation must not maintain an endowment larger than adequate to meet its current operating expenses. ${ }^{501}$ To determine the adequacy of its endowment, the foundation must use a set rate of return, proposed as eighty percent of the minimum required distribution of private foundations, upon its assets not employed directly to the active conduct of its exempt purpose. ${ }^{502}$ The Conference Committee reduced the set rate of return to sixty-six and two-thirds of the private foundation's minimum required distribution. ${ }^{503}$

\section{New and Amended Regulation}

Congress, based on the 1965 Treasury Report recommendations, amended several aspects of the Code's sections regulations applying only to private foundation, and added new ones. First, the House proposed limiting the tax exemption by imposing a seven and a half percent excise tax on foundation's investment income that private foundations may share in the nation's tax burden. ${ }^{504}$ The Conference Committee characterized the tax an excise tax and reduced the amount to four percent. ${ }^{505}$ Second, in line with the 1965 Treasury Report recommendation, rather than testing transactions against the arm's length standard, Congress prohibited all self-dealing between private foundations and their substantial contributors. ${ }^{506}$ Third, in response to the 1965 Treasury Report's recommendations against the accumulation of a private foundation's income, Congress

499. See id. at 1687 . The House stated that $85 \%$ would constitute substantial support. See $i d$. at 1688 . The House also included examples of organizations that met this test, being "learned societies, associations of libraries, and organizations which have developed an expertise in certain substantive areas and which provide for the independent granting of funds and direction of research in those specified substantive areas." Id. at 1687.

500. See S. REP. No. 91-552, at 2089.

501. See id.

502. See id.

503. Id. (discussing the Conference Committee establishing $6 \%$ as the minimum distribution for private foundations, thus applying $4 \%$ for operating foundations to their endowments).

504. See H.R. REP. No. 91-413, at 1663-64.

505. See Conf. ReP. No. 91-782 (1969).

506. See CONF. REP. No. 91-782, at 2392-93. 
mandated a minimum distribution for charitable purposes of a private foundation's income. ${ }^{507}$ Fourth, addressing the continuing criticisms associated with the control of family companies, Congress placed a twenty-percent restriction on the holdings of private businesses. ${ }^{508}$ Fifth, to halt the wealthy from using their private foundations for investment purposes, Congress tightened the rules regarding financial speculation. ${ }^{509}$ Sixth, Congress imposed a tax on political and lobbying activities. ${ }^{510}$ Seventh, Congress imposed new reporting requirements on all foundations, but religious ones. ${ }^{511}$ Finally, Congress raised the deduction ceiling to fifty percent, limiting it in certain situations for private foundation, and phased out the unlimited deduction for the wealthy taxpayers. ${ }^{512}$

\section{Limited Life}

The most radical proposal from the private foundations' perspective consisted of the Senate's attempt to limit the tax exemption of private foundations to forty years. ${ }^{513}$ The 1916 Walsh Commission, Reece Committee and Congressman Patman's first report carried the message, but Senator Albert Gore brought the proposal to bear on the Senate Floor. ${ }^{514}$ The Finance Committee Report based the need for the limitation on two factors. First, the Finance Committee, certainly relying upon Congressman Patman's reports and testimony, stated that private foundations, because of their increasing concentration of economic power, could manipulate both the private economy and

507. See Conf. REP. No. 782, 91st Cong., 1st Sess. 1969, 1969 U.S.C.C.A.N. 2391, at 2395; 1965 TREASURY REPORT, supra note 394, at 28-29.

508. See CONF. REP. No. 782, 91st Cong., 1st Sess. 1969, 1969 U.S.C.C.A.N. 2391, at 2396-97;; 1965 TREASURY REPORT, supra note 383, at 36. Both the Senate and House adopted Treasury's justifications nearly verbatim.

509. CONF. REP. No. 782, 91st Cong., 1st Sess. 1969, 1969 U.S.C.C.A.N. 2391, at 2397-98. The House proposed levying a complete confiscation of investments made "in such a manner as to jeopardize the carrying out of any of its exempt purposes" through imposing upon them a $100 \%$ tax, as well as punishing the managers who made them by imposing upon them a $50 \%$ tax. Id.

510. CONF. REP. No. 782, 91st Cong., 1st Sess. 1969, 1969 U.S.C.C.A.N. 2391, at 2398-99.

511. Conf. ReP. No. 782, 91st Cong., 1st Sess. 1969, 1969 U.S.C.C.A.N. 2391, at 2400-01; 1965 TREASURY REPORT, supra note 383, at 64.

512. CONF. REP. NO. 782, 91st Cong., 1st Sess. 1969, 1969 U.S.C.C.A.N. 2391, at 2406-07.

513. S. REP. No. 552, 91st Cong., 1st Sess. 1969, 1969 U.S.C.C.A.N. 2027, at $2052-$ 53.

514. Troyer, supra note 279, at 62; see 1965 TREASURY REPORT, supra note 383, at 56-57 (in which it called for a different solution whereby, after 25 years, the donor and donor's family could consist of no more than $25 \%$ of the foundation's governing board). 
governmental decisions. ${ }^{515}$

Second, the Senate distinguished the government's grant of tax exemption from the grant of the tax deduction for contributions. ${ }^{516}$ The government granted both the tax exemption and tax deduction based on the policy of government benefit. A foundation met its exemption obligation under this policy by employing its income for its charitable purpose. However, the Finance Committee pointed out that, in order for the foundation to meet the obligation as regards the charitable deduction, at some point the actual charitable corpus must be expended on the charitable purpose. The Finance Committee proposed that after forty years, a private foundation would lose its tax exempt status unless it had either morphed itself into an operating foundation or public charity. ${ }^{517}$ Senator Walter Mondale led the floor fight in soundly rejecting this proposal. ${ }^{518}$

\section{E. Private Foundation's Excise Tax}

The Ways and Means Committee, proposing a tax on investment income, aligned to the arguments proffered by exemption critics of the $1850 \mathrm{~s}-1890 \mathrm{~s}$, stating: "Your committee believes that since the benefits of government are available to all, the costs should be borne, at least to some extent, by all of those able to pay. Your committee believes that this is as true for private foundations as it is for taxpayers generally." "519 Second, the Ways and Means Committee justified the proposal based upon Treasury's need to cover foundations' audit costs, that Treasury could ensure that foundations employed their funds for their charitable purposes. ${ }^{50}$ The House thus proposed a $71 / 2$ percent tax on foundations' net investment income. The Senate Finance Committee accepted the second Ways and Means justification for an audit fee, but rejected the first based on the theory that a tax on investment income would infringe upon the policy of charitable tax exemption granted to foundations. ${ }^{521}$ The Senate thus proposed an excise tax upon foundations' noncharitable assets of one-fifth of one percent to create an audit

515. S. REP. No. 552, 91st Cong., 1st Sess. 1969, 1969 U.S.C.C.A.N. 2027, at 2052.

516. Id.

517. Id.

518. Troyer, supra note 279 , at 62.

519. H.R. REP. No. 413, 91st Cong., 1st Sess. 1969, 1969 U.S.C.C.A.N. 1645, at 1663; see supra Parts V, VII(B) and also exemption proponent Senator Hill's remarks in 1894 at Part VIII.

520. H.R. REP. No. 413, 91st Cong., 1st Sess. 1969, 1969 U.S.C.C.A.N. 1645, at 1663.

521. S. REP. No. 552, 91st Cong., 1st Sess. 1969, 1969 U.S.C.C.A.N. 2027, at 205354. 
fund for Treasury. ${ }^{522}$ The Conference Committee adopted the House's proposal of a tax on investment income, though compromising the rate down from $7 \frac{1}{2} 2$ percent to four percent, but in order to preserve the policy of charitable tax exemption, called it an excise tax. ${ }^{523}$

\section{F. Private Foundation's Self-Dealing}

As to self-dealing, Congress adopted the Treasury's recommendation to prohibit certain transactions between a foundation and its disqualified persons. The Ways and Means Committee used Treasury's justification that the arm's length standard required "disproportionately great enforcement efforts, resulting in sporadic and uncertain effectiveness of the provisions" and that Treasury and the Courts were reluctant to apply the loss of tax exemption sanction. ${ }^{524}$ The Senate Finance Committee further added that its reform rested "on the belief that the highest fiduciary standards require that self-dealing not be engaged in. ${ }^{, 525}$ The Senate presented a statement by the American Bar Association's Ethics Committee an example of the highest fiduciary standard, that it is "improper for an attorney to purchase assets from an estate or an executor or personal representative, for whom he is acting as attorney. Any such dealings ordinarily raise an issue as to the attorney' individual interest as opposed to the interest of the estate or personal representative whom he is representing as attorney. While there may be situations in which after a full disclosure of all the facts and with the approval of the court, it might be proper for such purchases to be made in virtually all circumstances of this kind, the lawyer should not subject himself to the temptation of using for his own advantage information which he may have personally or professionally ...., ,526

Congress prohibited the following transactions: (1) sale or exchange, or leasing, of property; (2) lending of money or other extension of credit; (3) furnishing of goods, services, or facilities; (4) payment of compensation (or payment or reimbursement of expenses); (5) transfer to, or use by or for the benefit of, a

522. Id. at 2054 .

523. CONF. REP. No. 782, 91st Cong., 1st Sess. 1969, 1969 U.S.C.C.A.N. 2391, at 2392; see Troyer, supra note 279, at 61 (noting that the collected excise tax goes into general government revenues rather than set aside for I.R.S. monitoring as proposed).

524. H.R. REP. No. 413, 91st Cong., 1st Sess. 1969, 1969 U.S.C.C.A.N. 1645, at 1664; 1965 TREASURY REPORT, supra note 383, at 21.

525. S. REP. No. 552, 91st Cong., 1st Sess. 1969, 1969 U.S.C.C.A.N. 2027, at 2056.

526. Id. at $2057-58$. 
disqualified person of the income or assets of a private foundation; and (6) agreement by a private foundation to make any payment of money or other property to a government official. ${ }^{57}$ Disqualified persons included substantial contributors to the foundation, the foundation managers, and the ancestors, descendants, and spouses of either. ${ }^{528}$ Dealing with the issue that the loss of exemption imposed a disproportionate sanction for Treasury to normally apply, Congress enacted a graduated tax penalty upon both self-dealing parties to the prohibited transaction, the disqualified self-dealer and the foundation manager. ${ }^{529}$

\section{G. Private Foundation's Minimum Distribution}

The Congress next turned its attention toward the Treasury Report's recommendation for a minimum distribution requirement. The Ways and Means Committee pointed out two situations, gleamed from Treasury's analysis, that would violate the tax subsidy / government benefit policy. ${ }^{530}$ Foundations, while receiving the benefit of the charitable deduction, invested in assets that did not necessarily create income, thus forestalling charitable expenditure. Second, even for income producing assets, under the current regulations, charitable expenditure could be stalled until the accumulation became unreasonable, and then loss of exemption offered the only penalty for ignoring the distribution policy.

Following Treasury's recommendation, the House proposed that a foundation be required to annually distribute its net income. ${ }^{531}$ Expanding Treasury's call for a minimum distribution

527. CONF. REP. No. 782, 91st Cong., 1st Sess. 1969, 1969 U.S.C.C.A.N. 2391, at 2393.

528. Conf. REP. No. 782, 91st Cong., 1st Sess. 1969, 1969 U.S.C.C.A.N. 2391, at 2393. The Conference Committee accepted the Senate's definition of substantial contributor, being "any person who contributes more than $\$ 5,000$ to a private foundation if such amount is more than 2 percent of the contributions received by the foundation before the end of the year in which the foundation receives the contribution of the person." Id.

529. Id. at 2394. For the disqualified self-dealer, Congress imposed a first tier 5\% tax on the amount of the prohibited transaction, followed by a $200 \%$ tax should the transaction not be unwound. Id. For the foundation manager entering into the prohibited transaction, a first tier tax of $2.5 \%$ subject to a maximum ten thousand dollar amount, followed by $50 \%$ tax subject to a maximum ten thousand dollar amount. Id. at 2393-94. In order to avoid an unreasonable burden upon the foundation managers, Congress granted them leniency to the application of the tax in that the government held the burden of proof to show the foundation manager willful, and without reasonable cause, violated the rule. $I d$.

530. H.R. REP. NO. 413, 91st Cong., 1st Sess. 1969, 1969 U.S.C.C.A.N. 1645, at 1669.

531. Id.; 1965 TREASURY REPORT, supra note 394, at 28-29. 
based on a foundation's non-charitable assets to curtail foundations that invested in non-income producing assets, the House proposed a five-percent distribution rather than three to $3 \frac{1}{2}$ percent. $^{532}$ Copying Treasury's suggestion, to qualify as part of the minimum distribution calculation, the foundation's expenditures must be made to public charities', private operating foundations, direct expenditures for charitable purposes, and expenditures for assets to be used for charitable purposes. ${ }^{533}$

The Senate agreed with the House's proposals, but amended two aspects which the Conference Committee accepted. ${ }^{534}$ First, the Senate Finance Committee clarified that the excise tax, unrelated business income tax, and reasonable administrative expenses would be deducted in calculating the annual minimum distribution amount. ${ }^{535}$ Second, the Senate Floor increased the minimum payout percentage to six percent of assets. ${ }^{536}$ The House and Senate agreed on a progressive tax sanction that would ensure a foundation's compliance with the minimum distribution rules, thus promote the government benefit policy. Congress imposed an initial tax of fifteen percent on the nondistributed portion of the annual minimum distribution amount, thereafter increasing the tax to one hundred percent of the nondistributed portion if the foundation did not correct its oversight. ${ }^{537}$

\section{H. Private Foundation's Prohibited Activities}

In addressing the taxation of sponsored activities not within a charitable purpose, primarily political lobbying, the Senate Finance Committee stated: "In general, the committee's decisions reflect the concept that private foundations are stewards of public trusts and their assets are no longer in the same status as the assets of individuals who may dispose of their own money in any lawful way they see fit. ${ }^{538}$

Congress prohibited private foundations from employing

532. H.R. REP. NO. 413, 91st Cong., 1st Sess. 1969, 1969 U.S.C.C.A.N. 1645, at 166970.

533. Id. at 1669-70; 1965 TREASURY REPORT, supra note 383, at 26-27.

534. Conf. ReP. No. 782, 91st Cong., 1st Sess. 1969, 1969 U.S.C.C.A.N. 2391, at $2395-96$.

535. S. REP. No. 552, 91st Cong., 1st Sess. 1969, 1969 U.S.C.C.A.N. 2027, at 2063.

536. CONF. REP. No. 782, 91st Cong., 1st Sess. 1969, 1969 U.S.C.C.A.N. 2391, at 2395.

537. Id. Congress set the correction period within ninety days of receiving notice of the failure to meet the minimum distribution obligation. Id.

538. S. REP. NO. 552, 91st Cong., 1st Sess. 1969, 1969 U.S.C.C.A.N. 2027, at 2075. See Dr. Eliot's argument for exemption based on the same principle supra Part VII(C). 
funds on political lobbying and elections, grants to individuals but for on an objective and nondiscriminatory basis, grants to non-public charities unless the foundation maintains responsibility for the grants use, and for any purpose not coming within their exempt purpose. ${ }^{539}$ Congress employed a progressive tax sanction similar to the self-dealing rules, upon the foundation and the foundation manager. ${ }^{540}$ The foundation first pays a tax of ten percent of the misspent amount, increasing to one hundred percent should the foundation not undo the violation, while the foundation manager who knowingly allowed the violation first pays a tax of $2 \frac{1}{2}$ percent, maximum five thousand dollars, increasing to fifty percent, maximum ten thousand dollars if the action remains uncorrected. ${ }^{541}$

\section{Universal Reporting Requirements}

Finally, Congress increased the reporting requirements on private foundations, as well as public, non-religious, ones. ${ }^{542}$ For all foundations, the new reporting requirements included:(1) return the names and addresses of all substantial contributors, directors, trustees, and other management officials, and of highly compensated employees. ${ }^{543}$ Additionally, private foundations reports included: (1) lists of assets showing book and marked values; (2) lists of grants (including amounts and purposes thereof); and (3) grantees' names. Further, Congress required the foundations to make their required reported information public, though non-private foundations could keep their contributors list confidential. ${ }^{54}$ Also, in order to support the states in enforcing their charitable corporate and tax laws, Congress directed Treasury to share information of a foundation's violations with the relevant state. ${ }^{545}$

539. S. REP. No. 552, 91st Cong., 1st Sess. 1969, 1969 U.S.C.C.A.N. 2027, at 207578; see Troyer, supra note 279, at 60; Simon, supra note 390 , at $71 \mathrm{n} .17$ (noting specific testimony that led to the various prohibited activities rules). By example, Congressman John Rooney, New York, testified that his campaign opponent used foundation funds under his control to make grants to churches in exchange for political speeches. Id. Also, the Ford Foundation admitted to giving grants to Senator Robert F. Kennedy's staff to ease the transition to the private sector. Id.

540. CONF. REP. No. 782, 91st Cong., 1st Sess. 1969, 1969 U.S.C.C.A.N. 2391, at 2400 .

541. Id.

542. Id. at $2400-01$.

543. Id. at 2401 .

544. Id. The Senate Finance Committee proposed the protection of non-private foundations donor lists because public disclosure could curtail anonymous gifts. Id.

545. S. REP. NO. 552, 91st Cong., 1st Sess. 1969, 1969 U.S.C.C.A.N. 2027, at 2081. 


\section{J. Universal Applicability of the Unrelated Business Income $\operatorname{Tax}$}

Based on the justification of inequitable treatment amongst foundations, Congress imposed a phase in of the unrelated business income tax rules to all exempt organizations including religious organizations. ${ }^{546}$ The House and Senate Committees stated that some churches owned many businesses, including "... hotels, factories, ... radio and TV stations, newspapers, parking lots, record companies, groceries, bakeries, cleaners, candy sales businesses, restaurants, etc. ${ }^{547}$ Moreover, Congress imposed regular corporate tax upon the investment income of social clubs and employee beneficiary associations. ${ }^{548}$ The Senate Finance Committee stated:

Since the tax exemption for social clubs and other groups is designed to allow individuals to join together to provide recreational or social facilities or other benefits on a mutual basis, without tax consequences, the tax exemption operates properly only when the sources of income of the organization are limited to receipts from the membership. Under such circumstances, the individual is in substantially the same position as if he had spent his income on pleasure or recreation (or other benefits) without the intervening separate organization. However, where the organization receives income from sources outside the membership, such as income from investments (or in the case of employee benefit associations, from the employer), upon which no tax is paid, the membership receives a benefit not contemplated by the exemption in that untaxed dollars can be used by the organization to provide pleasure and recreation (or other benefits) to its membership. ${ }^{549}$

546. Id. at 2096. Organizations caught by the new application included "churches and conventions or associations of churches, social welfare organizations, social clubs, fraternal beneficiary societies, employees' beneficiary organizations, teachers retirement fund associations, benevolent life insurance associations, cemetery companies, credit unions, mutual insurance companies, and farmers cooperatives formed to finance crop operations." Id.

547. Id.

548. Conf. ReP. No. 782, 91st Cong., 1st Sess. 1969, 1969 U.S.C.C.A.N. 2391, at

549. S. REP. NO. 552, 91st Cong., 1st Sess. 1969, 1969 U.S.C.C.A.N. 2027, at 2100. 
The Committee accepted the Senate's proposal to maintain the tax exemption for amounts employed for charitable purposes by fraternal beneficiary associations and employees beneficiary associations. ${ }^{550}$ Finally in regard to unrelated business income, Congress imposed tax on foundations' advertising and related income associated with profitable activities, such as publications and trade shows that produce a net income, but granting minor exceptions. ${ }^{551}$

\section{K. Charitable Deduction}

The Ways and Means Committee proposed increasing the charitable deduction for non-private foundations from thirty percent to fifty percent, but phasing out of the unlimited deduction. ${ }^{552}$ The Committee justified this deduction increase based on maintaining a strong incentive for middle and upper income taxpayers to contribute to charitable institutions. However, the Committee proposed repealing the unlimited deduction because "high-income taxpayers should be allowed to minimize or avoid tax liability by means of the charitable contribution deduction." ${ }^{353}$ The Ways and Means Committee did

550. ConF. REP. No. 782, 91st Cong., 1st Sess. 1969, 1969 U.S.C.C.A.N. 2391, at 2405. The Senate provided the example of fraternity and sorority organizations providing student loans, scholarships, and leadership schools. $I d$.

551. S. REP. No. 552, 91st Cong., 1st Sess. 1969, 1969 U.S.C.C.A.N. 2027, at 2105. The Senate provided an example that for a trade show's income not to be taxable, "the activities producing the income for the association from the show - that is, the promotion, organization and conduct of the exhibition - contribute importantly to the achievement of the association's exempt purpose, and as a result the income is related to its exempt purpose." Id.

552. H.R. REP. No. 413, 91st Cong., 1st Sess. 1969, 1969 U.S.C.C.A.N. 1645, at 1697. The House proposed not increasing the deduction for contributed appreciated property that would create a capital gain if sold by the taxpayer. Id. However, regarding certain categories of property, such as appreciated art and future interests, the taxpayer is required to accept the tax liability, the House stating:

Your committee does not believe the charitable contributions deduction was intended to provide greater - or even nearly as great tax benefits in the case of gifts of property than would be realized if the property were sold and the proceeds were retained by the taxpayer. In cases where the tax saving is so large, it is not clear how much charitable motivation actually remains. It appears that the Government, in fact, is almost the sole contributor to the charity. Moreover, an unwarranted benefit is allowed these taxpayers, who usually are in the very high income brackets.

Id. at 1670 .

553. H.R. REP. No. 413, 91st Cong., 1st Sess. 1969, 1969 U.S.C.C.A.N. 1645, at 1697. Referencing the reason stated in the House's preamble, the Committee determined that high taxpayers' most important deduction to avoid most or all tax was the charitable deduction. Id. at 1697-98. The Committee gave as example that one hundred taxpayers 
not propose increasing the deduction for private foundations. The Senate Finance Committee, agreeing with the justification provided by the House, proposed extending the fifty percent deduction to private operating foundations and to private foundations that distribute the contributions with the year to private operating foundations or public charities. ${ }^{554}$ The Conference Committee accepted the Senate's proposal with the modification allowing the private foundation an extra $2 \frac{1}{2} 2$ months after the year of contribution to distribute the funds. ${ }^{555}$

\section{XIV.CONCLUSION}

Charity is an important part of the United States economy and social psyche. Since the turn of the century, Congress and the states have uniformly granted tax exemption to charitable foundations, and shortly thereafter tax deductions for charitable donations. However, the topsy turvy nature of how the charitable foundation tax exemption has come to be regulated is proof positive that America is divided on how to deal with exemption status and charitable donations. A cursory review of the Congressional policy and Treasury reports with regard to tax exemptions indicates the repetitive nature of the 1850 s and 1870 s policy debate enunciated by James Parton and Dr. Charles Eliot. This review also proves that, for the most part, the charitable exemption is deserved though sometimes, by private foundations, abused. This is not to say that the present regulations are correct in their assumption that private foundations should be treated differently than others or that private types of foundations abuse their exemption status more than others. What should be said is that the present system may not be as effective as it could be. Among the many debates, reports, and testimony was evident that even "good" foundations such as churches and schools, have abused their exempt status.

It is apparent that for the future private foundations will continue to receive tax exemptions, though it is not certain as to which organizations will still be considered private foundations.

with greater than one million dollars income leveraged the unlimited charitable deduction. $I d$. at 1698.

554. S. REP. NO. 552, 91st Cong., 1st Sess. 1969, 1969 U.S.C.C.A.N. 2027, at 2107. The Senate also proposed extending the 50\% deduction for the basis amount in contributed property, leaving only the appreciation subject to the $30 \%$ deduction rate. Id.

555. CONF. REP. NO. 782, 91st Cong., 1st Sess. 1969, 1969 U.S.C.C.A.N. 2391, at 2406-07. The Conference accepted the House's proposal to leave appreciated property at the $30 \%$ deduction threshold unless the taxpayer elects to realize the appreciated amount for tax purposes. $I d$. 
Based on the first hundred years, it is also apparent that this pubic policy debate will continue to re-iterate its hundred-yearold arguments. 
